\title{
ECONOMIC DEVELOPMENT OF PAKISTAN
}

\author{
by
}

Niaz Mohammad

A Thesis

submitted to the faculty of the

Department of Fconomics

in partial fulfillment of the requirements for the degree or MASTER OF ARTS

in the Graduate College, University of Arizona

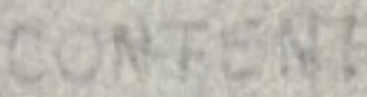

1951

Approved: $\frac{\text { Dhe }}{\text { Director or inesis }}$

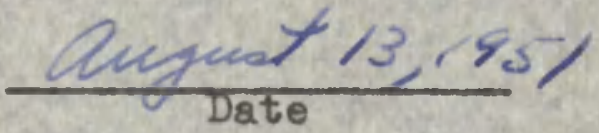




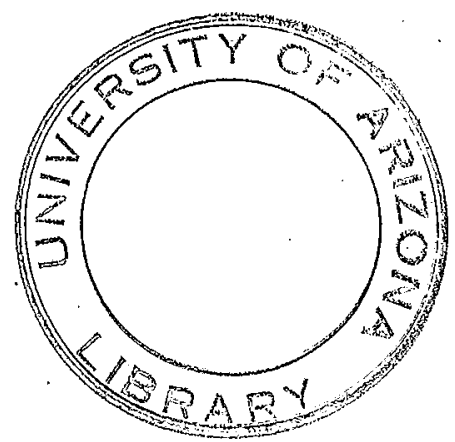


TABLE OF CONTENTS

Chapter

Page

PREPTACE vi11

I. PAKISTAN ON THE GLOBE .......... 1

Historical - Retrospective ....... . 2 Muslims in Ind1a ............ . 2 Hindulsm . . . . . . . . . . . . 3 Hindu-Muslim Relations ......... 3 The British Conquest $(1707-1947)$.... The Muslim Renalssance . . . . . . . The Indian National Congress and the All India Mus Iim League The Const1tutional Reforms The Constitutional Reforis $\cdot \cdot \cdot \cdot \cdot \cdot$ Muslim Reaction: Demand for Pakistan . The Second World War . . . . . . . The Postwar Situation......... The Birth of Pakistan . . . . . . . Economic Dislocation and Consequences. Other Developments . . . . . . . .

\section{1}




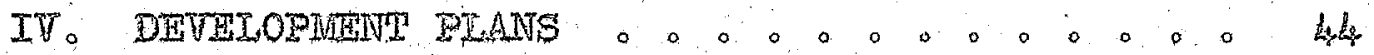

Types or Sohemes: Historical Bakground o 46 Disisibution of Schemes, Unitorise and

Subjectrovitse $00000 \%$

Agrieultural Derelopment : o. o o o

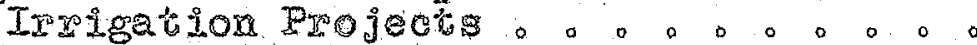

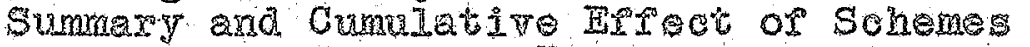

Relation of State to Industry o. o. 。 Assistance to Industry o0。0。0。

Tanion Concession

Forejgn Capital o o o o o o o o o o o

Industries Subject to Central Planning.

52

$\nabla \circ$ INDUSTR AND IITIING $000 \%$

Largensede Industies 0.0 .0 .0 .0

Juse 00.0000000000000 Cotton Tercile Industry Woollon Teztiles a $0.0 .0 .000 \%$ Sugaz and Aleohol Industries 0.0 Cemert 0.0 .0000 .000 .000 .00 Heary Chemicals o o 0.000 .000 Sulphuric Asid a 0 Caustie Soda . Soda Ash o o o o o o o o o 0.000 .0

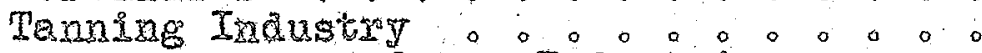

Derelopment of other. Industies o. Problems of the cotrage Industry. . . Measures. Adopted by the Centro]

Covernont Cottage Industros in Pakistan 0 : : Rowex Resouges o a o o o o o o o o o Hineral Resources 0.000 .00000 Cogl

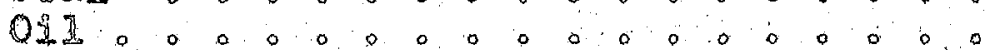

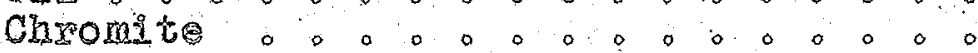

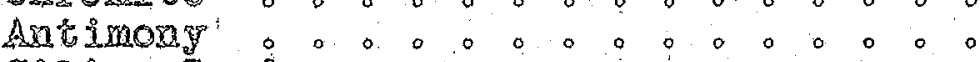

S111 ca Sand o 0 o 0 o 0 .

Sulphurs 0

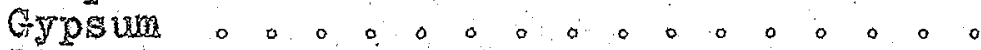

81

81

IInestone $0.000000 \therefore 0.000$

82 SQ 1 t 
VI. LABOR AND ERTLONMENT

Featres of Rakistan E Eonomy o. . . 84

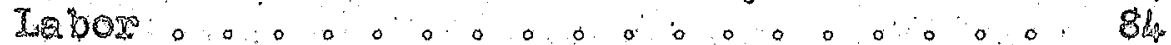

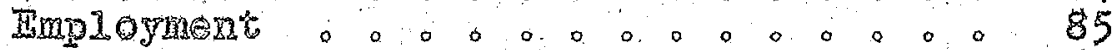
Erro loyment Hahanges 0.000 .007

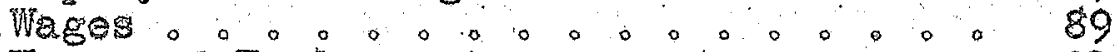

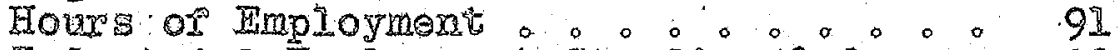
Indugtial Holognent Standing Ordex? 92 Industrial Relations $\therefore \circ 00 \%$. 0.092

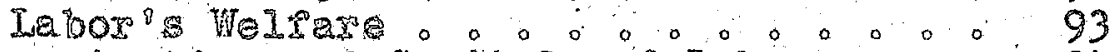

Oxganizations of Capital and Labor .0 .94 Capital 0.0.0.0.0.0.0.0.0.0. 94

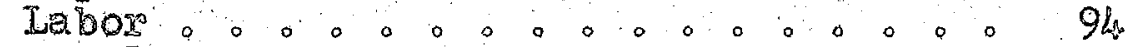

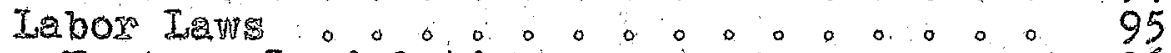
Paroty Legislation o 00.0 .000 Payment of Wages Act $1936 \div 0 \%$ Industzial Disputes Legislation: a a 97 Trede Union Act, $1926 \circ \%$ Workmea's Compensetion Aet ig23: : 98 The Meteraity Benepit Act 00009 The Emplogers Iivbility Act, $1938^{\circ} \circ \%$ of

VII. TRANSPOET AND CONMUNICATIONS - 0.0 .0 .99

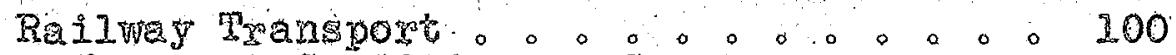
Wornout Condition of Stock $\circ: \circ \% 102$ Coal shor tage o. 0.0 .0 .03 Inporement in Train Serviles 0.0 . 103 Morement of Good 5 . $0.0 . \% \circ \%$ Roads $1.000000 \%$

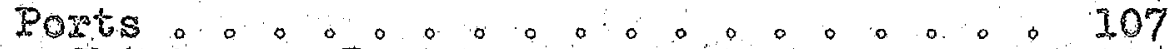
Chittagong Poxt o $0.00 .0 \% 0.108$ Water Transport 0.00000 .0 .00 .110

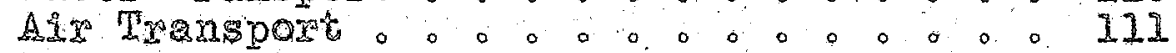

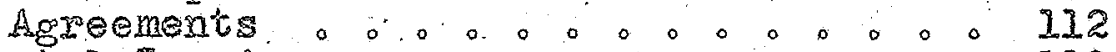
Postal Services $\circ .0 .000 .000 .113$ Telecommination 0.0 .0 .00113

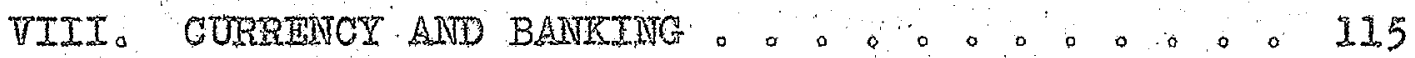

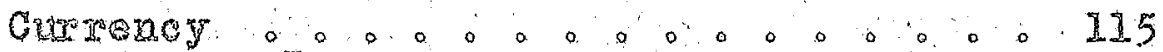

Security Prating Press。o-。。。

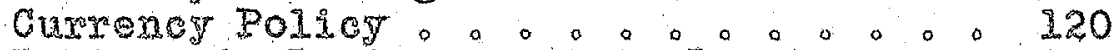
Pekistan's Decision not to Devalue $: 120$ Foroigh Bschange Regulations $0.0 \%$. 121 Banking o o 000000000.000122

The Monez Market o 0 o : 0 - o

The Centra 1 Bank 0.0 .00000123

Expanion in Banking System. 
VII: (eonto)

Industrial Finance Corporation $\circ \cdot .125$

Relugee Rehabilitation Finance

Coxporation a : 0.000 .00 .126

National Bank or Pakistar o o o o 0126

Cooperative Banks o \% \% 。

IX。 INTHERATIONAI TRADE $\circ \circ \circ \circ \circ \circ \circ \circ \circ \circ \circ 128$

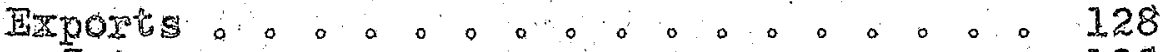

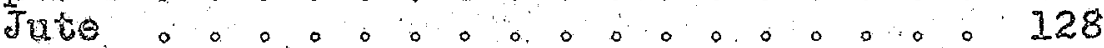

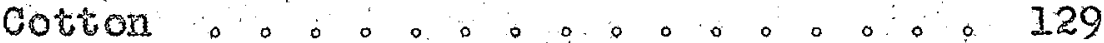

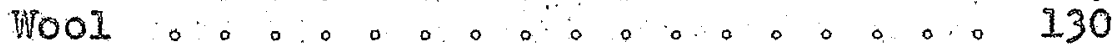

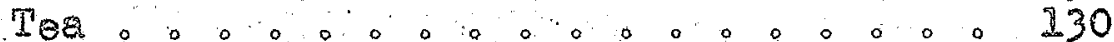

Hides and Skins $0 . \cdots 000 \cdots$

Impores $\div 000 \%$

Direction or Ser-Borne Trade, April I.

1949 aliar on $31,1950 \div 0 \% 133$

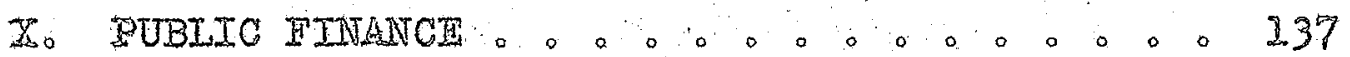

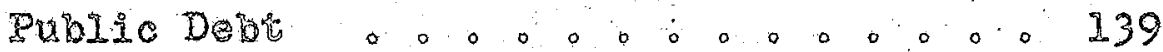
BIBEIOGRAPHY $00.000 \cdots 00^{\circ} 00000142$

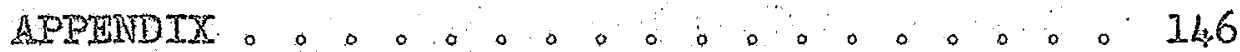




\section{IIST OF TABEES}

Hrumbar

Page

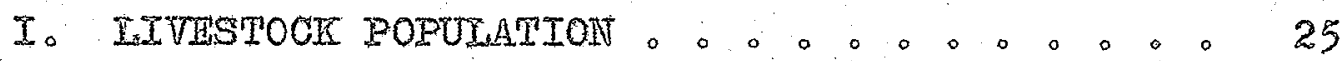

II CIESSTFICATION OF TOREST AREAS $\circ \circ \cdot 0.029$

III. CTASSTEIGATION OH IAND。。.

IV: RRTITIPAI CROPS OF PAKISTAIV 0.0000039

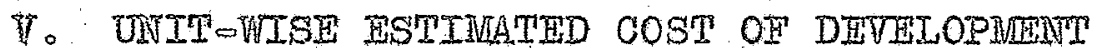
SCHEMES APRROVED BY DEVELOPMANT BOARD UP

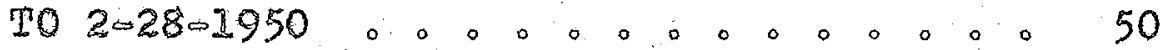

TI. SUBJECT SCHEMASS APPROVID BY DEVELOPNATIT BOARD UP

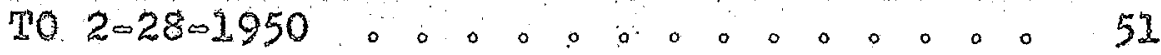

VII. INDUSTRIAI IABOR $00.00 \% 00 \% 000086$

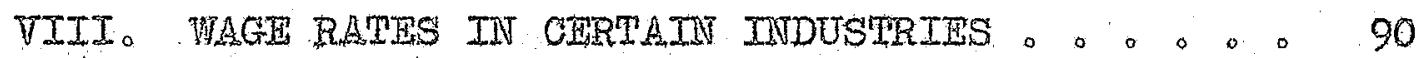

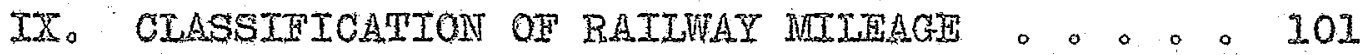

I。 ROAD HTLEAGT IN RAKISTAN $\cdots \cdots \cdots$

TI. WUNBER OF MOTOR VHHICLES ON ROADS $。 \circ .107$

XII. INPORTS AND EXPORTS AT THE TARACHI PORT :。108

XIII. PAKISTAN NOTAS 0.000 .000000 .979

XIV。 DISTRTBOPION OF OFETCES OF SCFHDULED BARES 125

XV. VATUE OF STA-BORNE EXPORTS TO PRINCIPAI

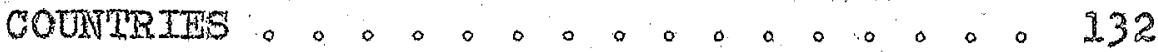

XVI. TALUE OF SEA-BORNE IMEORTS OF FOREIGN

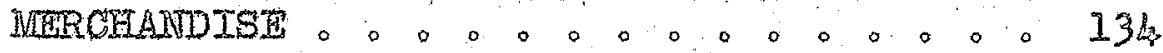

XVII. VAIUE OF SEA-BORNA IMPORIS FROUI PRINCIPAI COUNTRIAS $\circ 0.00 .00 \% 0.000 .0135$ 
XVIII. DIREGTION OF SRAOBORNE TRADE AND PIRCENTACE SHARE OF TARIOUS COUNTRIES

ZIS. PRINCIPAI HEADS OF REVENUE AND EXPENDITURE o, 140

\section{MLPS}

Bakistan on the Clobe 0 \% 00.0000 IS 


\section{PRESACE}

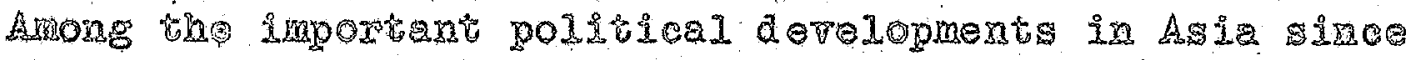
the Second. World Wat has been the energenes of India and Palistan por a depondent colonial position into pull solno rule. The old British "Indian Empire" on Augret 15,2947 we partioned and eech part granted dowinlon status in the British Commontrealth of Nations, Thus ended the epoch or Bistish domination in the land wich had had the mathex ing distinction of belng the world" greatest colonial pos Sosion。

The Ireconoiliability of the Indio and Islamio peoples moxe than any other cause led to the paxtition of the old India in 1947 and the creation of the nen nation, Pakistan. An atrempt has been made in the peges that pollow to introo anoe Pakistan por better and thorough understanding.

I am Texy gaterni to the mbssy of Paklstan, Washinge

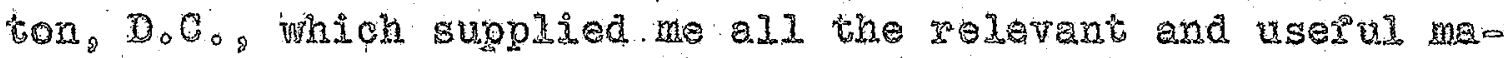
terial on the subjoet.

I an greaty indebled to Dy。 $P_{0}$ G Hudson, my propessor or economics, who has direced me in my thesis, made imo provemonts in ray draptid and given pluablo suggestions. I an very much Impressed by ing treasure of knowledge which he has about Rakistan, the keen interost which he has taken 
2n directing mo and puting thesis in shape. I am pope tunate to hate him a treaches and guide to whom I owe so meho whout his guidare I would hare been nowhere.

IV az Hohominad

July 25,1951 


\section{GHAPPTR I}

\section{PAKISTAN ON THE GLOBE}

The Dowhion of Pakstan cane into existono on the

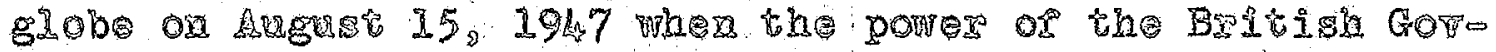

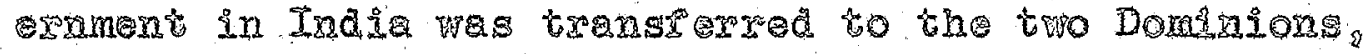

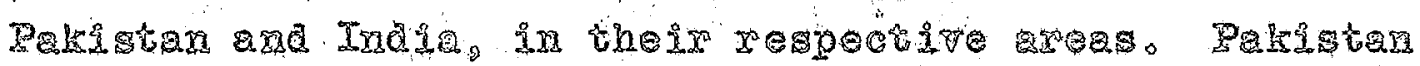
this has emerged rron colonialism to salpogowernment follow

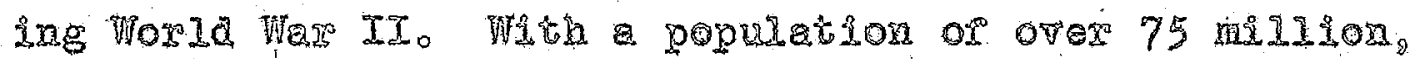

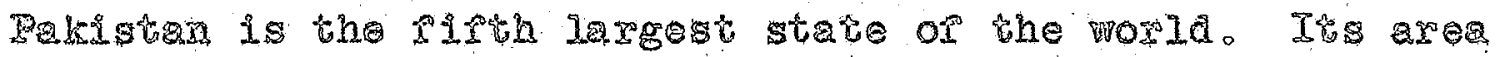
emoraces more than $350_{2} 000$ squase mixes.

What backgond of history and culture. phidosophy. ralugom and pocial tolationship has preparod the people of

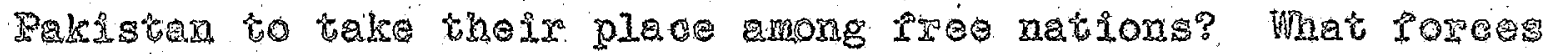
bind this huge population togithex, and mat pores led to the petition of the country into lodia and Paistan? The

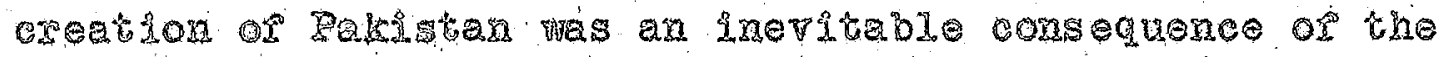

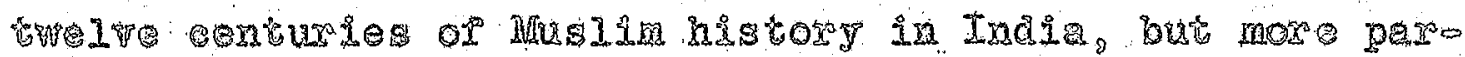
ticulary or the last two. In this chaptr it is proposed

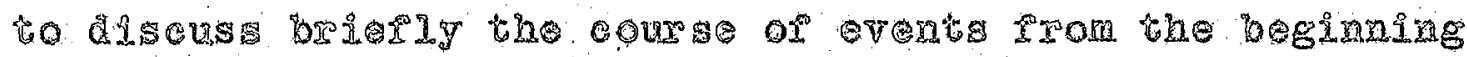

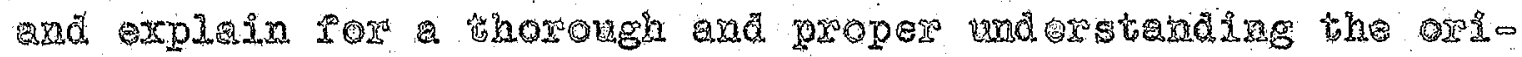

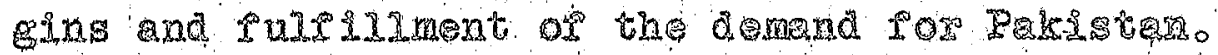




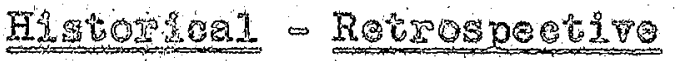

The frst political conector or Musims with India was the dyab conquest or Sind by Hohrma Bin Qasim in 722 A. Do and its anneration by the Caliohet of Damascus. The mider introduetion of Islam into Indid, howerer, was to

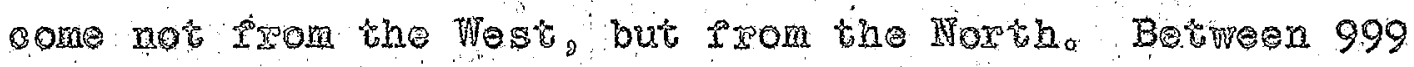
and 1025 A. D. the Sultar Hahad of Gam in Aphandsen mad 17 xads into Ixain torntory. Fire Turkish or

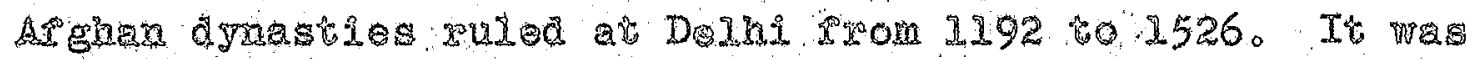

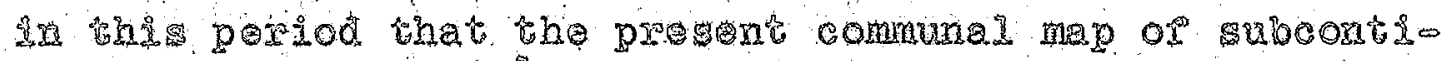
2

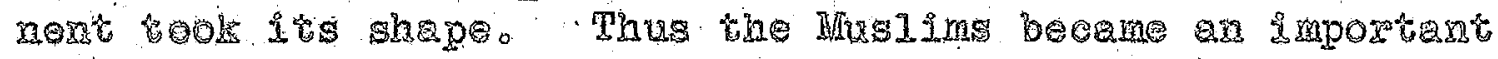

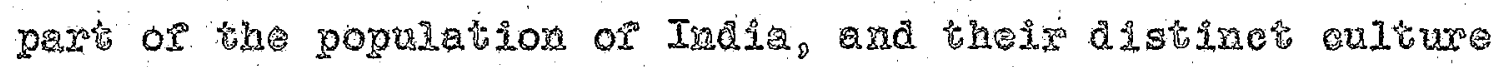
wes ostablished side by side with that or Hindus

\section{Hris lims In Indig}

Berore the ereaton of Pelistan in August, 1947, British India had a populatson of abort 400 ralilion: or these, apo

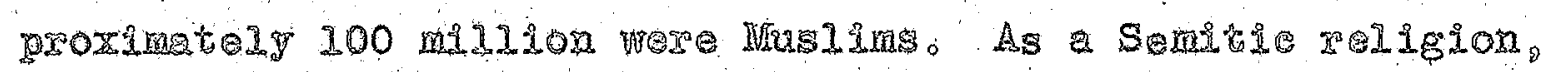

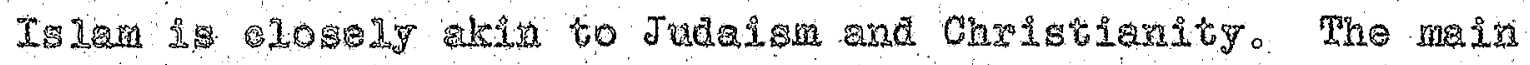
fundamental of Is Ia dre that there is ondy one Impersond

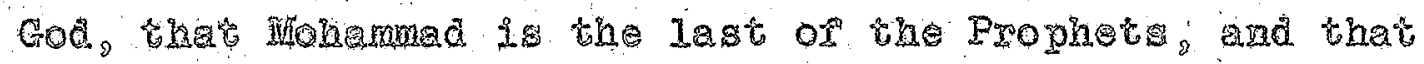

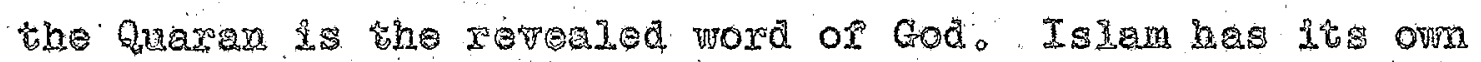

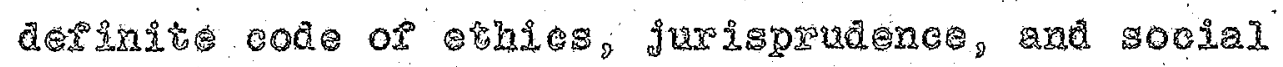

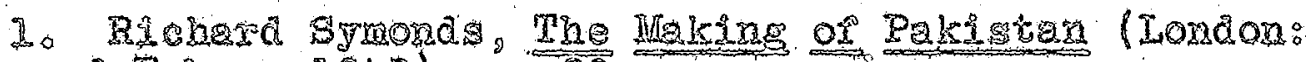
Tabex and taber, 1949), 2020。 


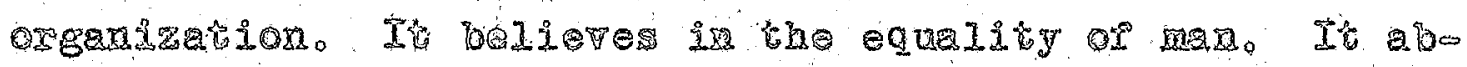
bors idolides

\section{Hiodusidg}

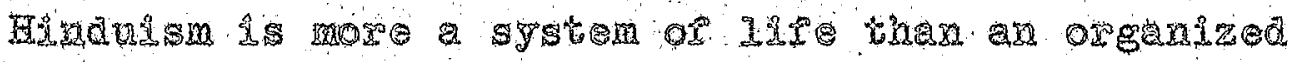
religion. It believes in an endess partheon of deltros. some of whom are worshippe others gropiciated. housenold has lits own god or goddess. Transmigration of soul is besic tonot or Hinduism. The most important pearure of Hinduism as a social oxthichetion is its easte system which 1s baged on the bellex that huma be ticular eastes and thet their whele life is gowerned by zigid xules of divine oxigin.

The sour mal casies are: Bramains, the priests, who

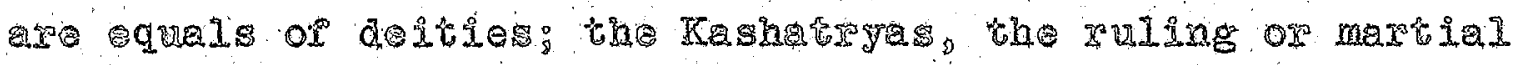
Q2asses: the Vaishyes, the agrieviturish and fraders: and

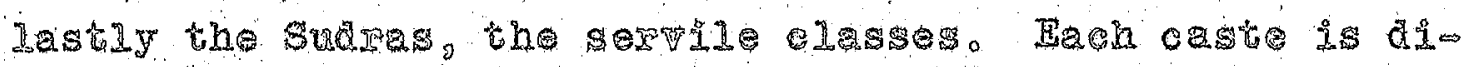
rided 2nto an endess array a subeastes. All Hindus wo

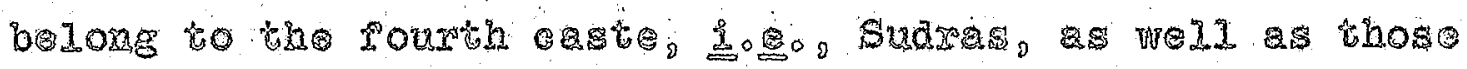

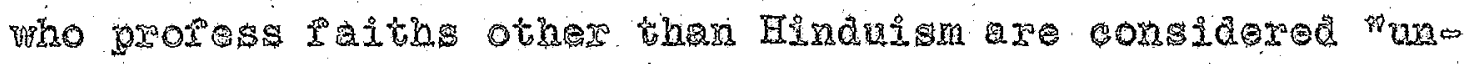
touchables.s?

\section{His}

Their rollgion and social conoopts boing so radically

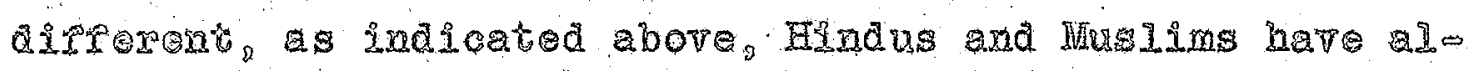

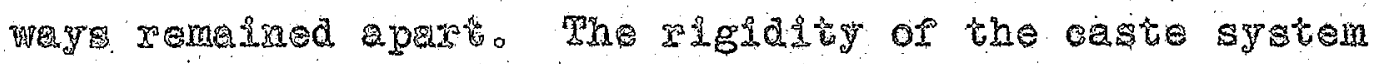

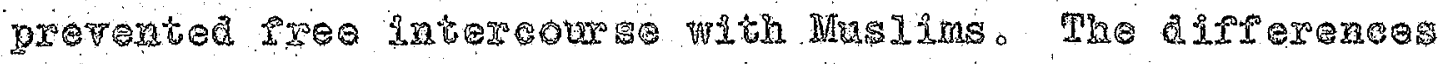


porsistod oven in such minor mators as dress, manners or

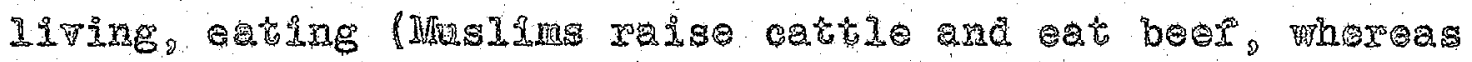

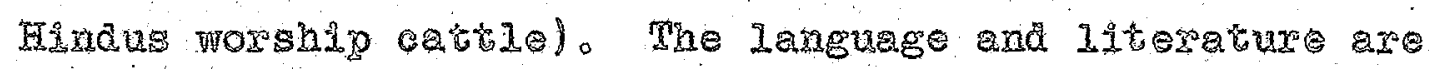

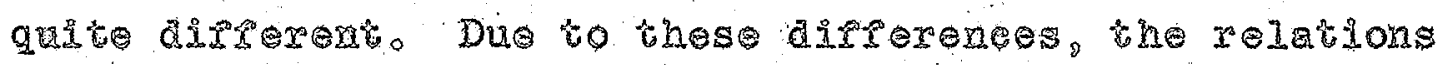
or both the nations have not been as a mer op ract oor

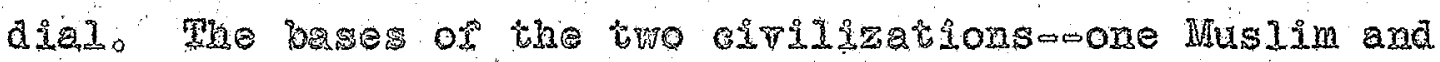

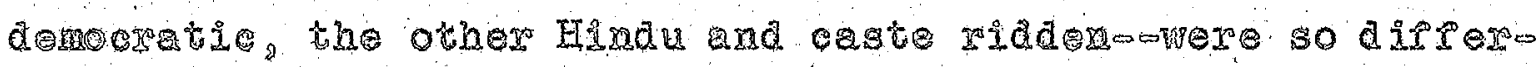

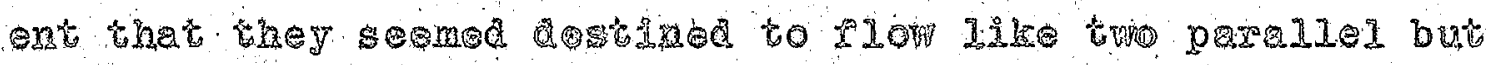
geprete stomen.

\section{The Brofish Conousis (1707.9217)}

The Britigh Irs came to Iada as tradars, the East

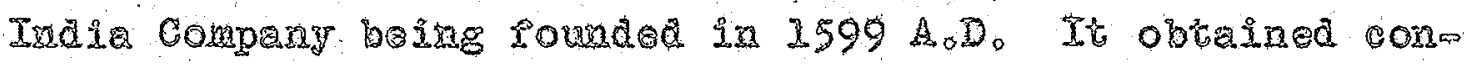

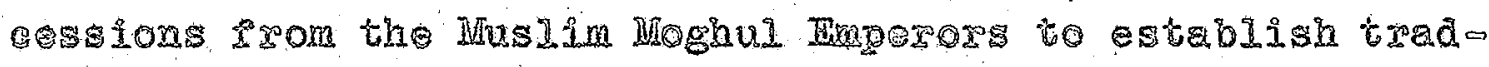
lag grtlanents at vardous posts. Aptex the death of

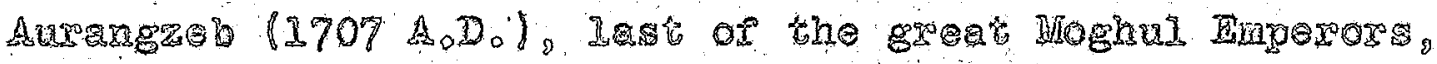

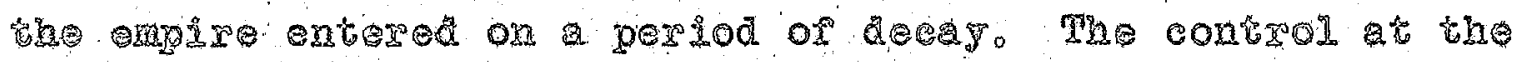
certer berano 2 ar.

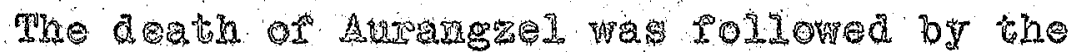

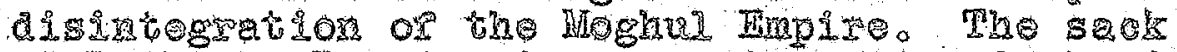
or Delni by Persian inders in 1739 and the in oreasing stresgers or British Freach and Dutch

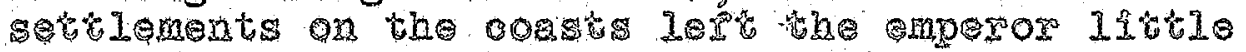
pore than moral a uthority and sentinental apo

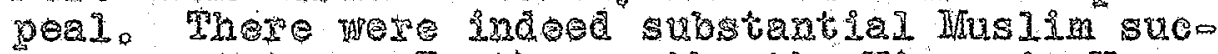
crsar states. In the south, the Wham in Fyo

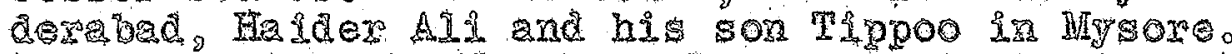
In the arth, the Nawah of Baxgal controlled most

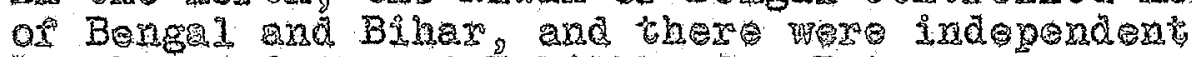

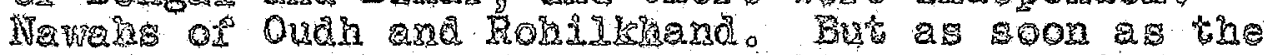
British Fast Traja Caxpany had disposed of itis Europers ritris, 31 inexorably absorbed both Hus I im and Hinde states. The Nawah or Bengel was

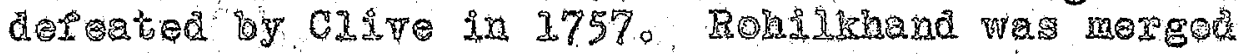


zoudh though British intexention in 177 . Thpoo mas dereated and kilied by nellesley ir 1799. D. InI was occupiod In 1803 。0 By 1850

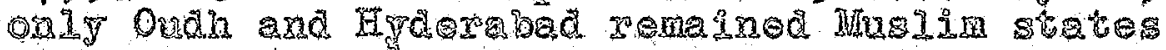
of conseguenerol

When Husins wete the rulers of India they had plled the great majority of the higher posts it the axrog the ato

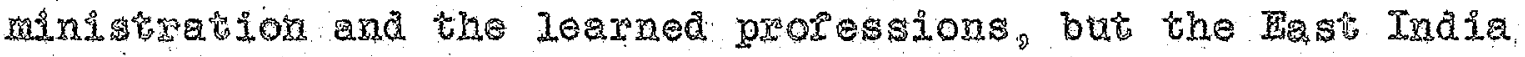
Company lere no suone untrised of cowse mith the a id or

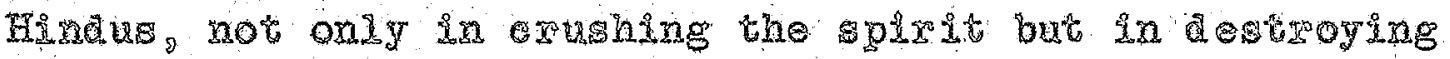

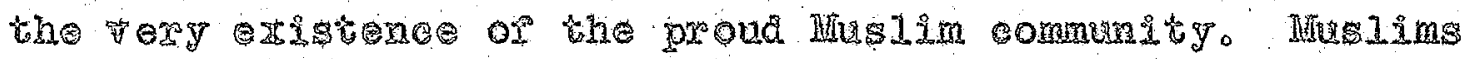
were shit out of the axy and thexe was no place por them in the goverament ories. In short, erexy honoxable we or life was closod to tho Musims and kisery was brought to

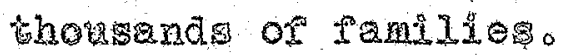

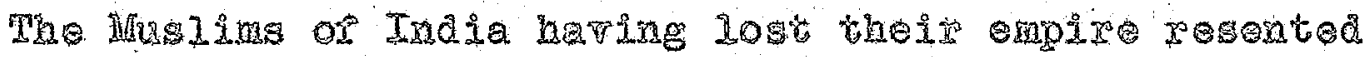
the intrusion of Britsh, and this wesentment led to gen

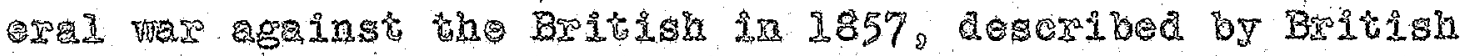

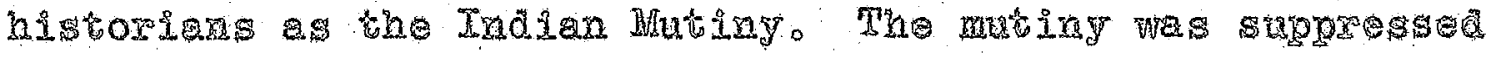

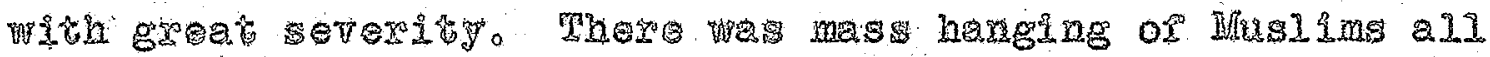

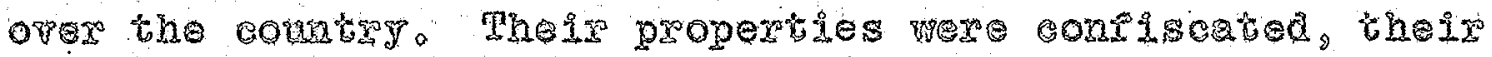

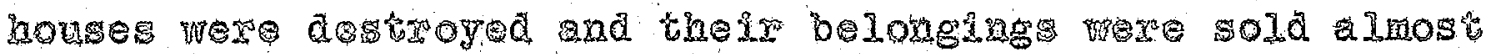

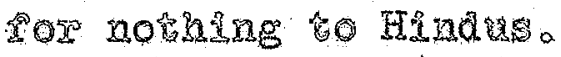

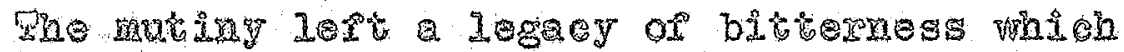
persisted ros at least a seneration but enea more

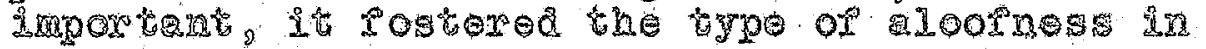

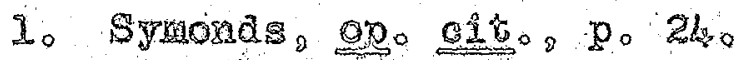




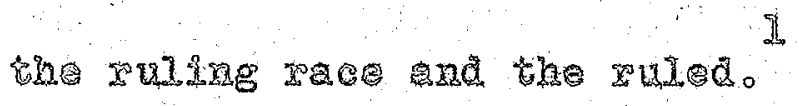

\section{The Mas In Rena issares}

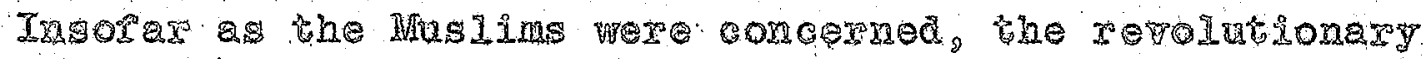

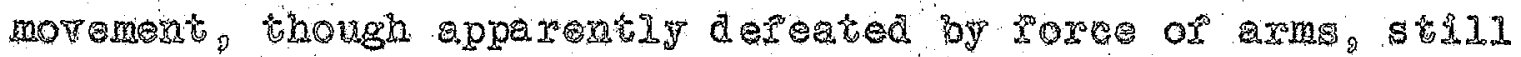

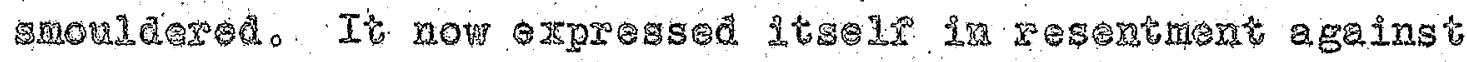

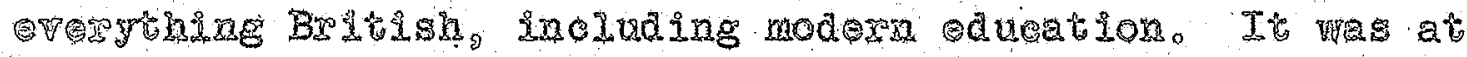
this exitical period that some Mfrstim leaders ma a doterm

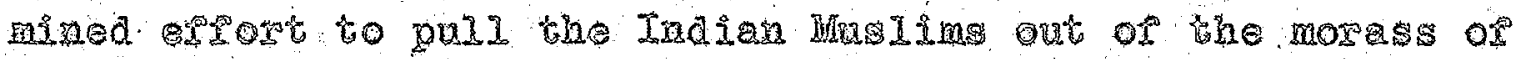

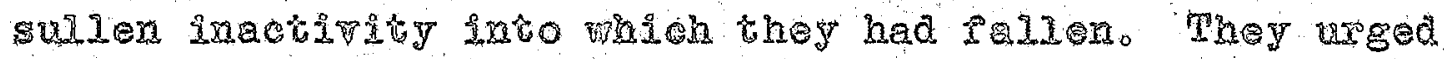
upon them the necesict or taking to modern oducaton, or

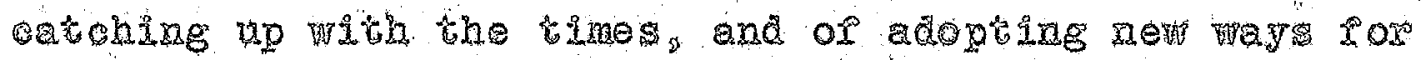
thghing the new menes. But a depeatod people takes Iong

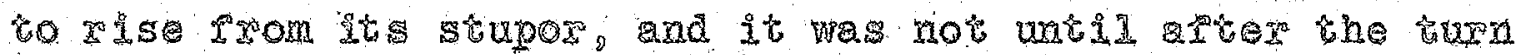
of the contury that the Nuslims amoke to the necessity of

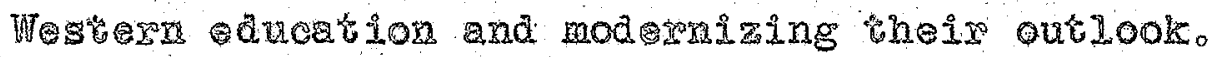

Meanhilo they had pllen about 50 gears bohind the

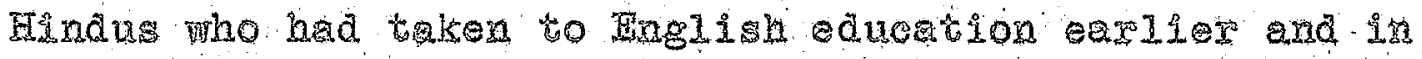

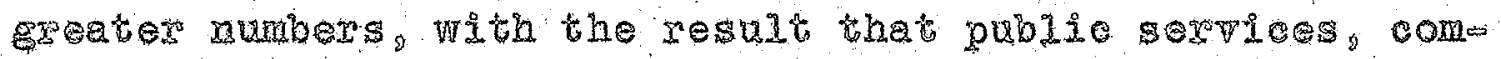

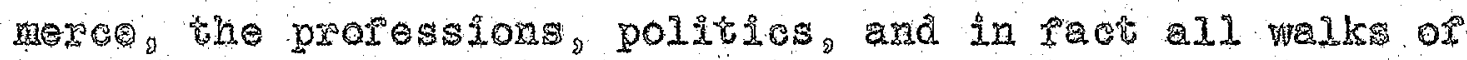
Iif mexe dominaed by Hidus. Bot the Muslims we aweno Ing an lajming an jnoreasing share in the life of the courtsisa

1. Wo Hosman Brom, India, Pakistex, CorLon (Nev Tow:

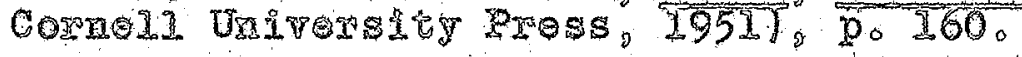




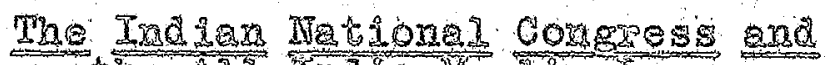

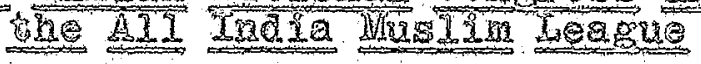

The Irdian Natonal Corgress, estabished in 1885, was

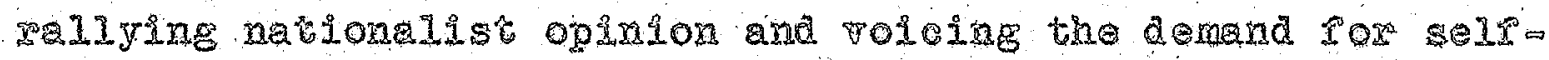

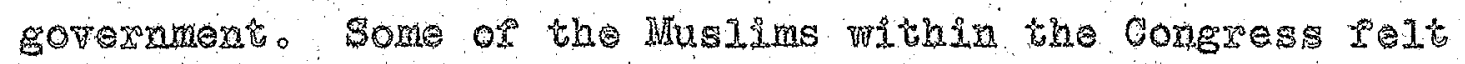

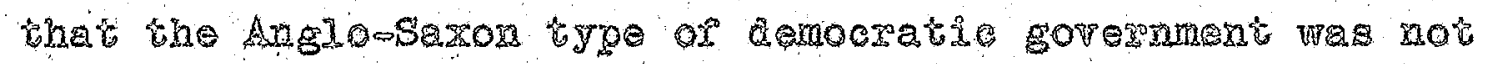

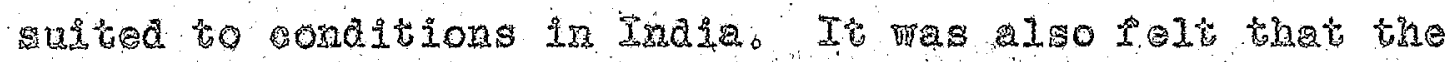
gystem or representation by eloction heans the representaton of the trews and interests or the mority of the popuc lation. Consequanty in 2906 the Husims cormed a separate

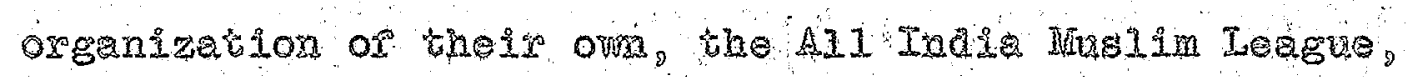

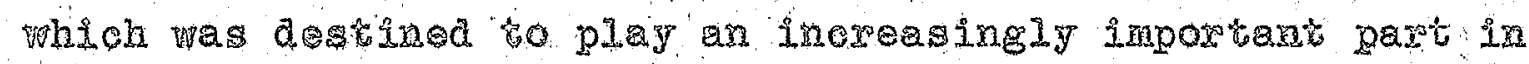
shaping the tutrase of Inag

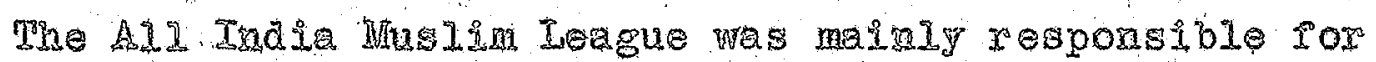

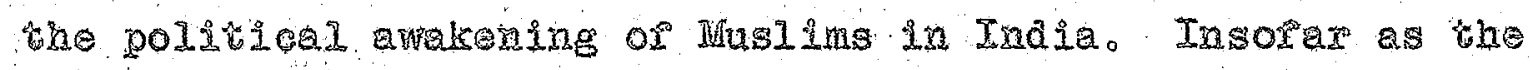
denad sor the polstack advaneoment of the country was conconed, it suppoxted the Indian Netionel Congress, but.

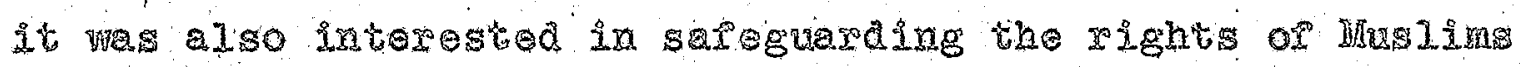
and proserving their sopaxate ldentity.

\section{The Constitutional Rororns}

To mee the publie cotielstand to supress the ago totion of the Indan totonal Congyess and the Ail India

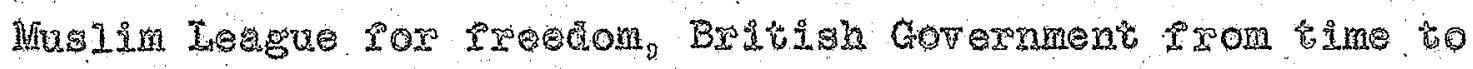
the ga substontial soroms in the Constuthon so that

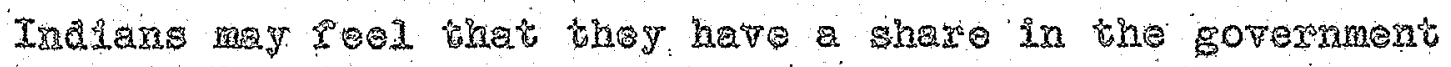




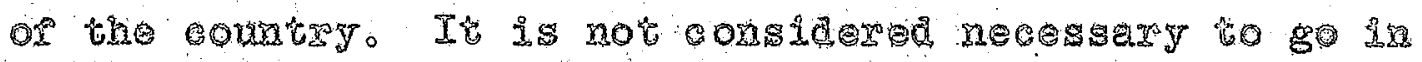

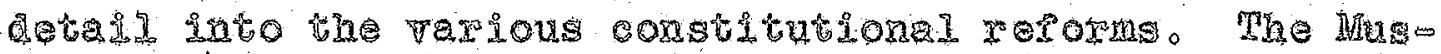
Iins, howerer, realized that whenerer relorms we given to the cownty they conld not take advatage of those yoroxtho

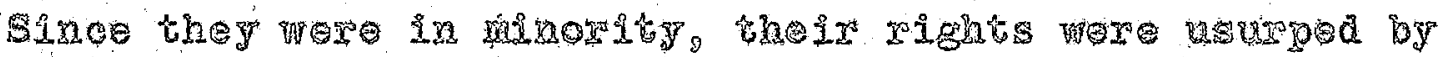
the joxict

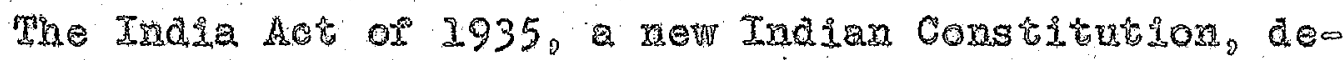

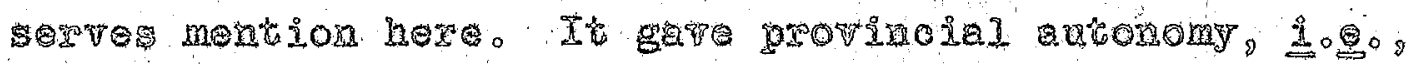

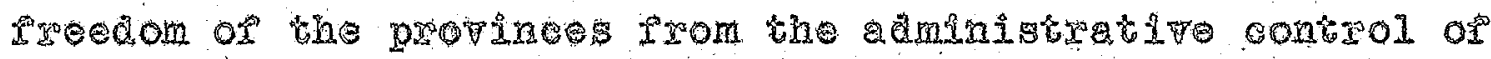
the canter, expot por peciric purposes and responsiole

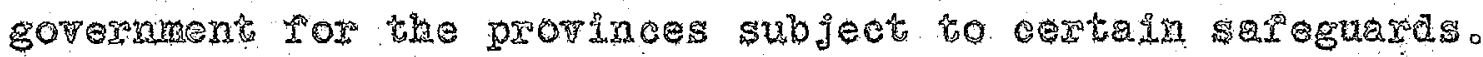

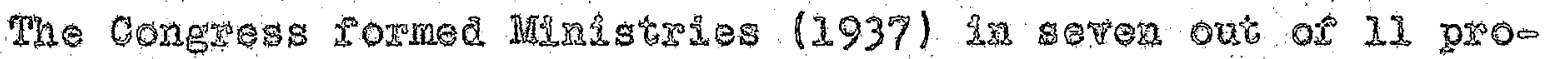

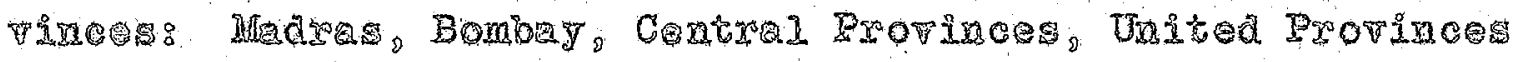

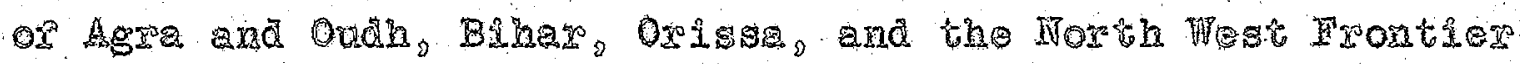

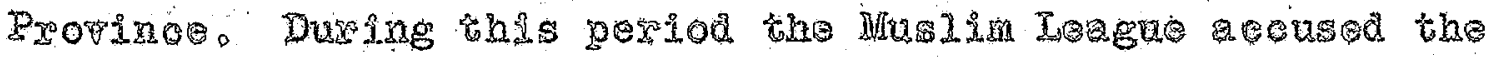
Congress of agtalishing Hidu tyranie in those proplaces

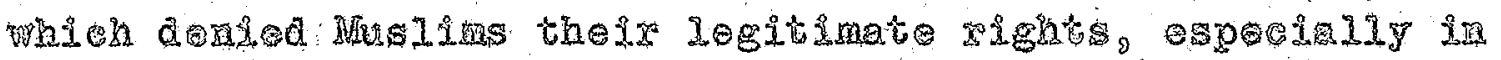

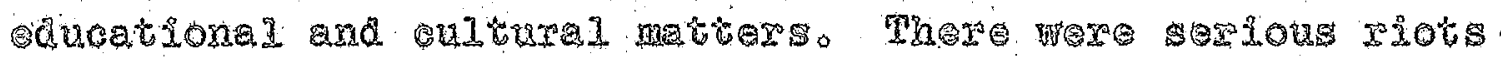

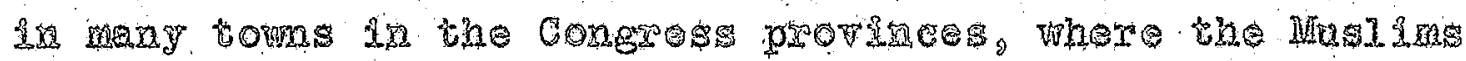
suprred the heaty loss of lire and property: weir entre

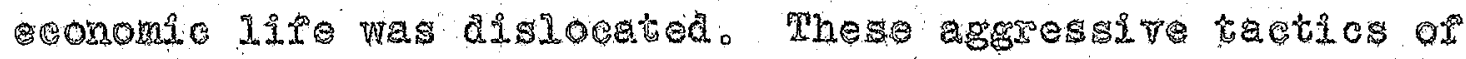

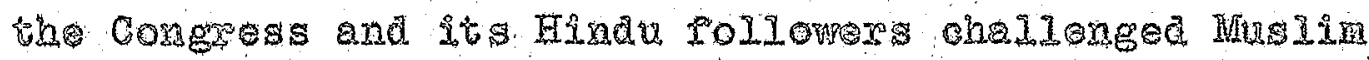

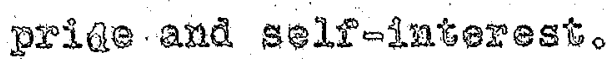

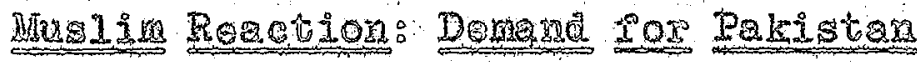

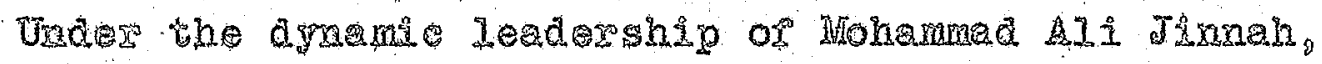

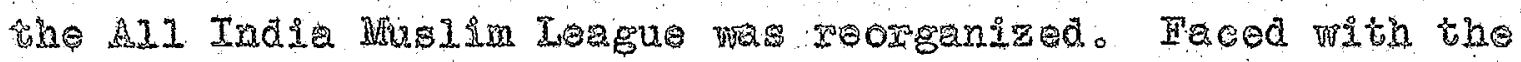


Sturtion ereated by the Congress, the Muslims reme now

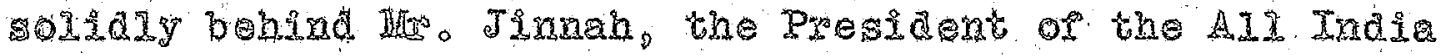
MusI Is League.

Wo power on eath a prevent Pakigan." said Jinnah In 1940, At the antual session of the teague hela in lahore. the historid Pakistar Resoluton was passed whoh denanded

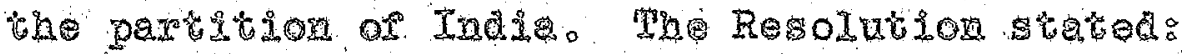

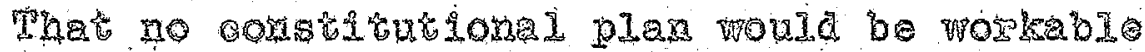

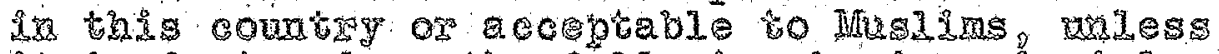

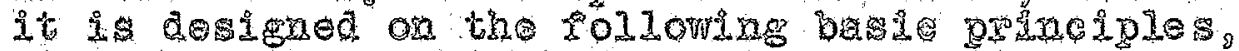

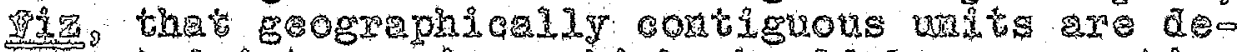

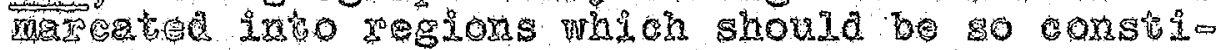

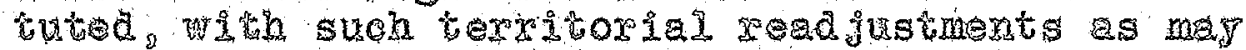

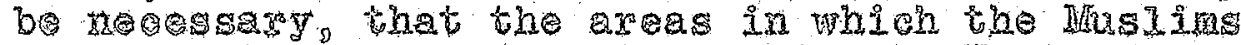

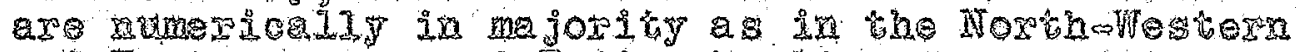

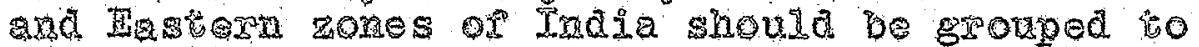

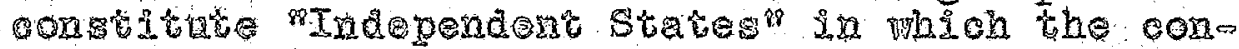

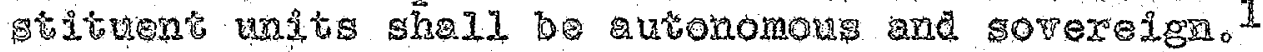

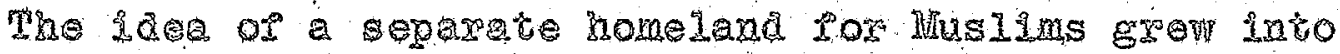

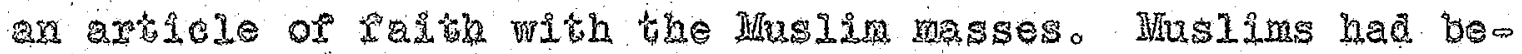
cone conscious that a peple they war ontrely direront

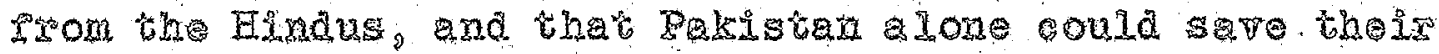

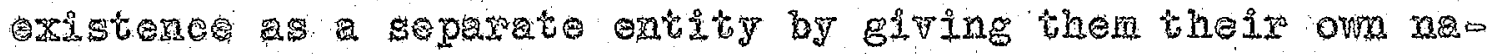

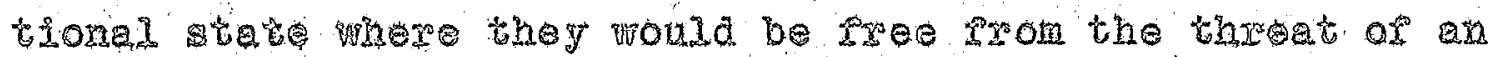

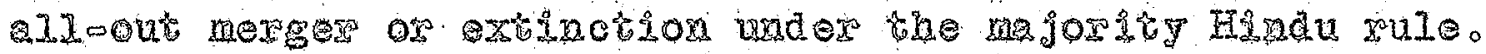

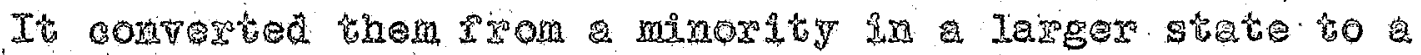

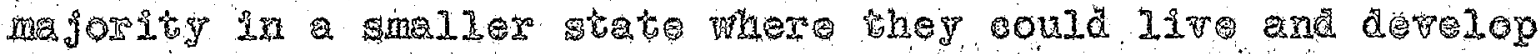
acording to thelr om genius. It also gave the an indeo pendent intexntional satus ia the world.

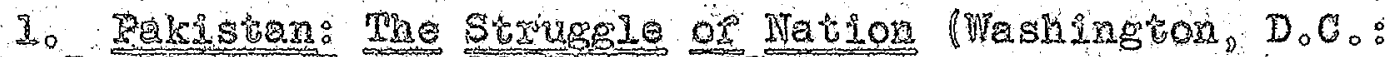

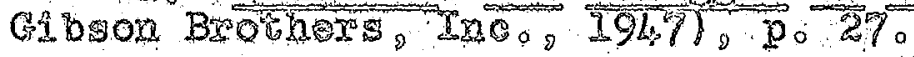


Paki gtan alone could enable the Huslins to temestabish theis economie Iise In an undirded India, the Hindus mould

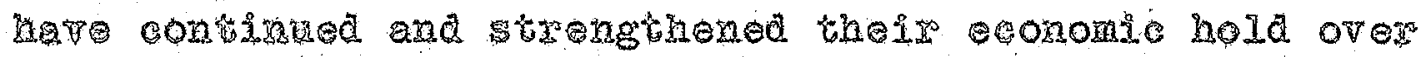

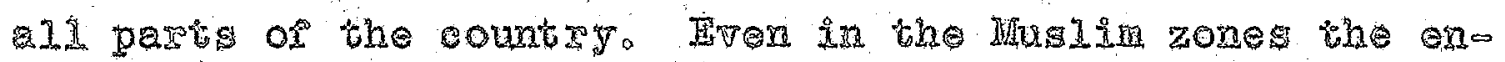
tire trad, baxing and industry wore alxed monopolized

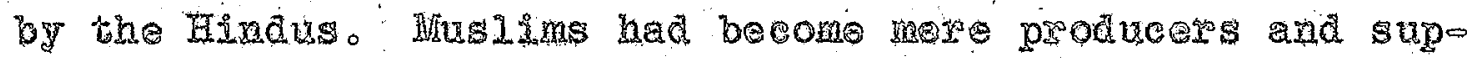

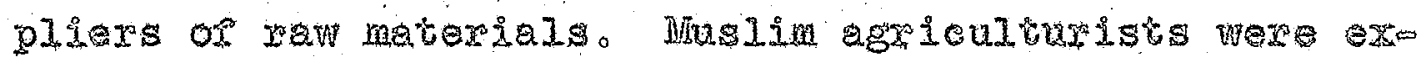
ploited by Hindu mereanile and nonetumang elasses. The

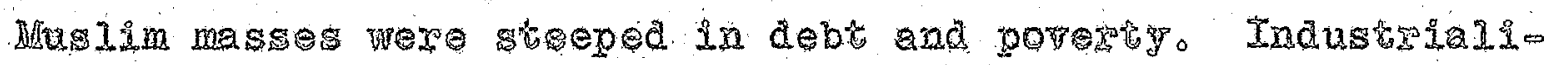

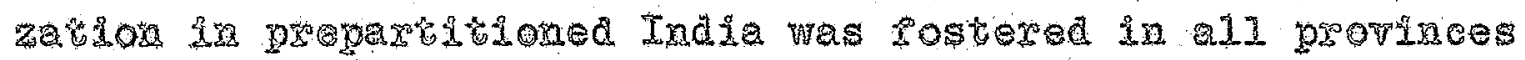

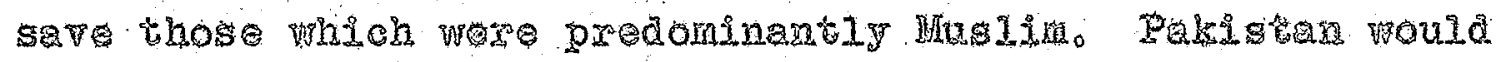
gut an end to this axploitation, estabish and protect its

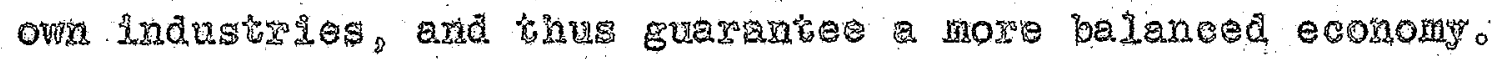

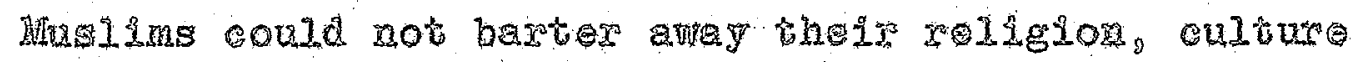

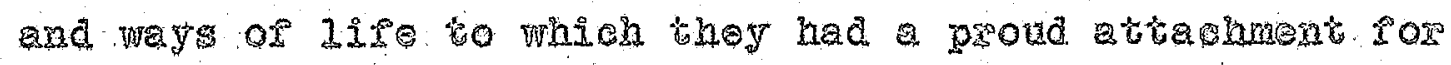

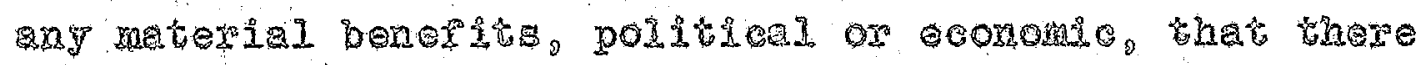

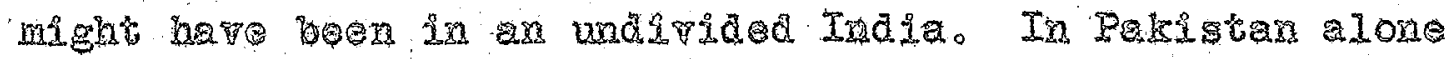

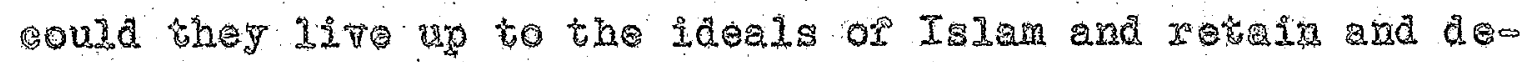
velog the segse of selsoxespect and pxide which is their historie hexitige

\section{Ihe Socond Horad Hax}

The second Hoxld Wro thu pound tho tro great Irdian conmuities more deeply divided the evero The Congress

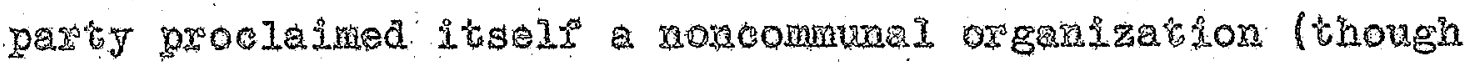

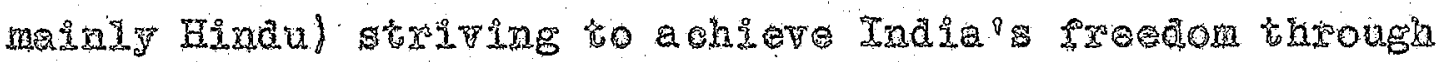




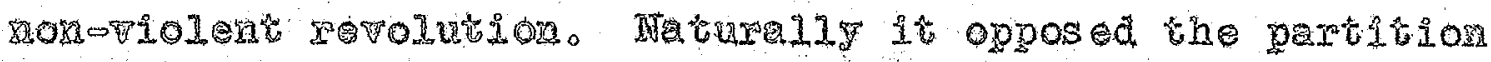

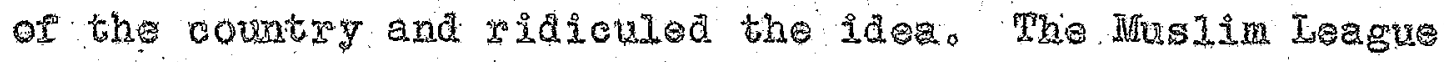
Pratky prosessec its commandsm and sought support as a

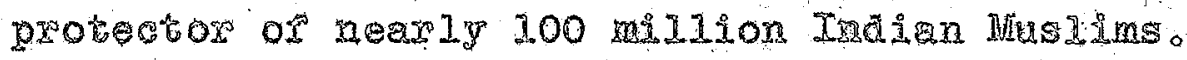

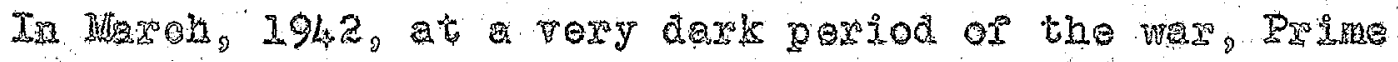
Hinister Stantore Cxops to Ind the oces

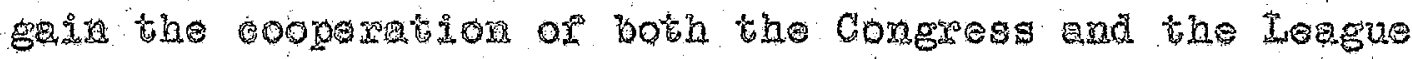
with the aristing goverament by trensterging to Inding on

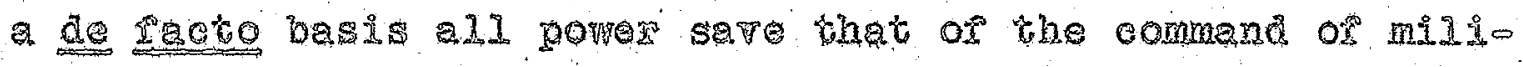

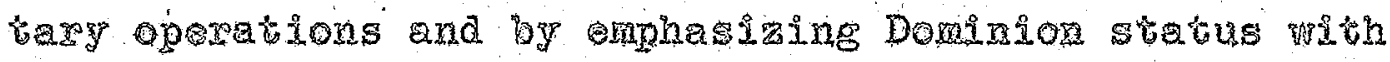

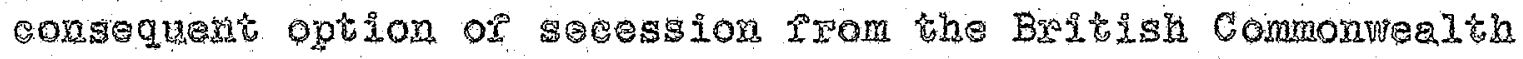

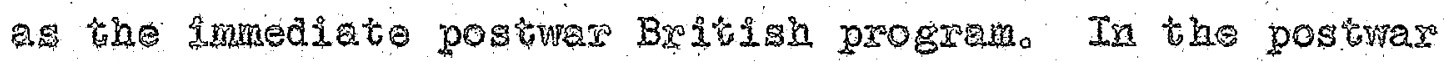
pars of the arter, howerer. the prowpet of partichor was hinted at in the provisions whereby aisserisied provinces could stay out of the proposed wrion of theis own on a Domiajon status basis.

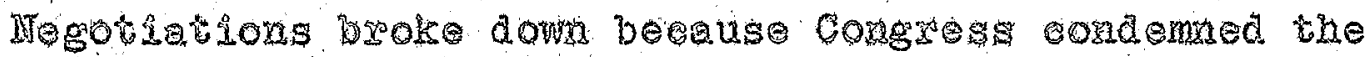

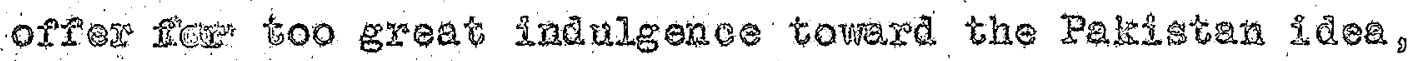

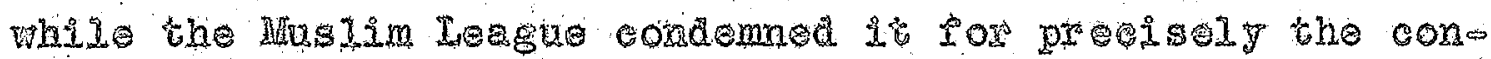
tray season。 pae political struggle in Iraie was dow a

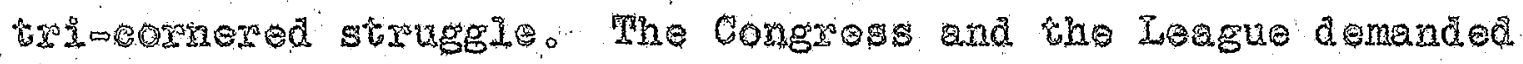
complete indendere the League demanded the esablinhent of Takistar by the patejor of India: the Congress opposad

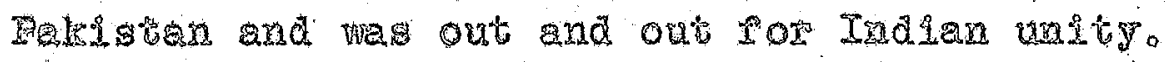




\section{Dho Postwas Situation}

Then war eame to an end, politica seoling in India ren wery high. The entro population was pastonarely ans

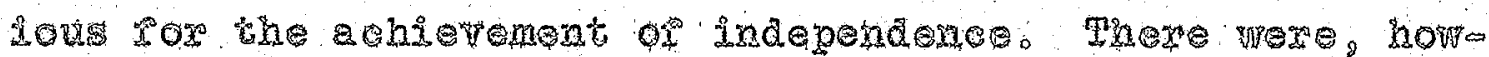

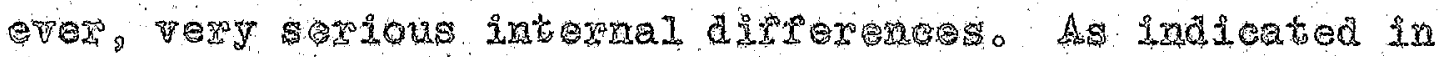

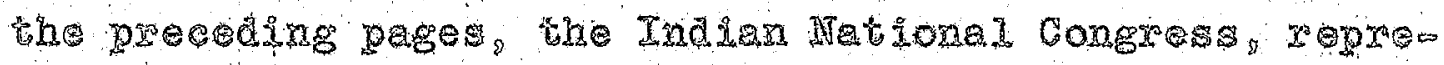
senting maly the Hadus, wanted the power of the British

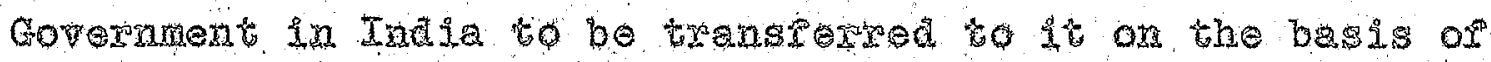
the whole of trala being one poltticel wits The All Indib Muslin teagu, on the othex hand, representing the entre Hus Iin population of India, demaded the portition of the

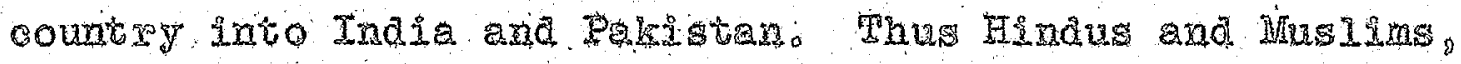

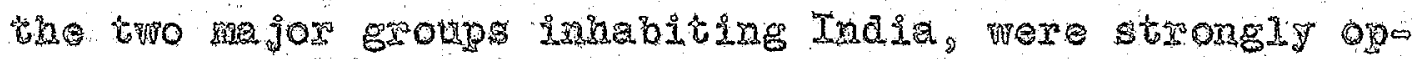

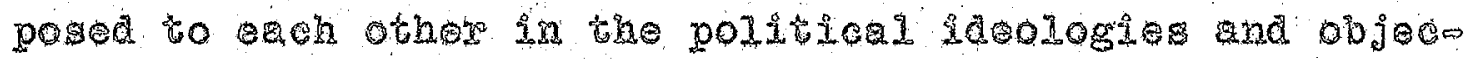

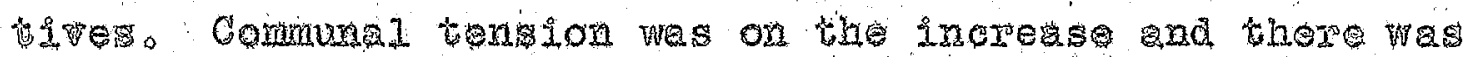

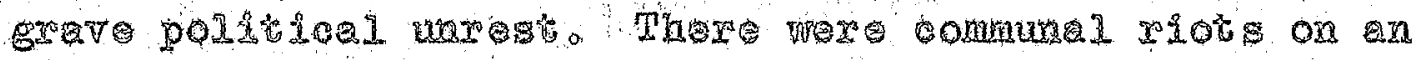

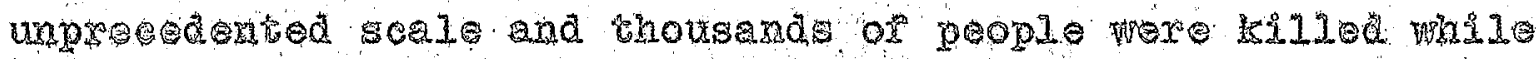

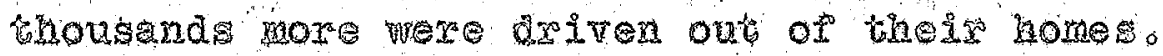

The Butish Gorexnent in Ha 1946 optered a solvton. to the poitticl groblem in whe is know as the Cabine

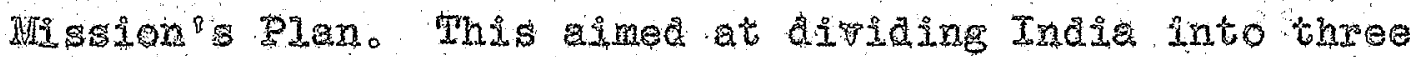
groups, so that the Hublit majoxity areas could be grouped

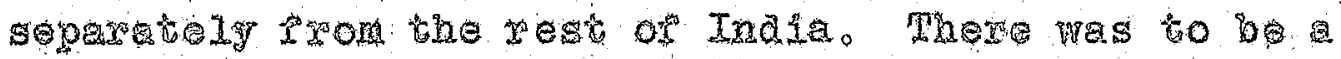

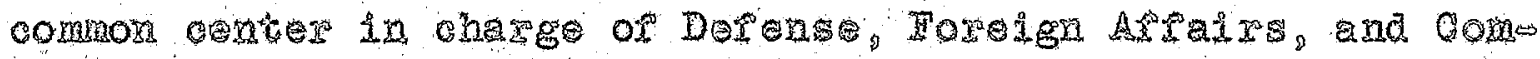

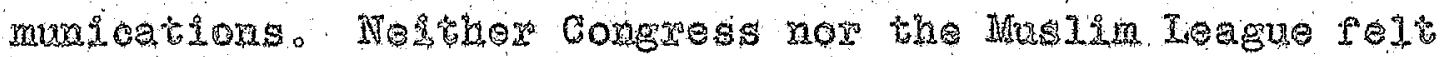

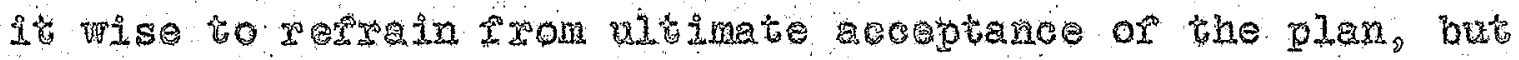


both parties wer angaged in a dispte as to rajous points or Interpretation: tord Navell, the then Tieeroy or India, succed in induelng Nehru and Jinnah to $\mathrm{TIy}$ to London

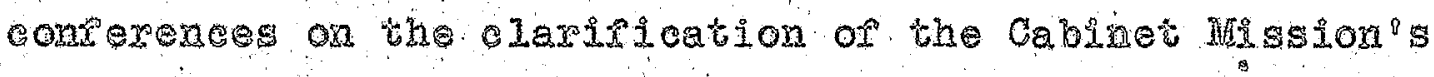
Plar.

Tho British Corerment in the meanime decided (Febru

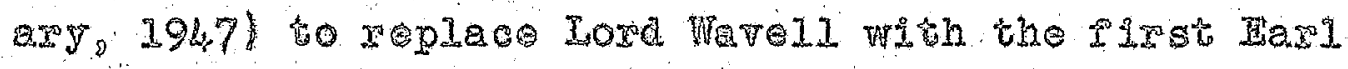
Whountoton or Burma, and to nnounoe that Brotida mould

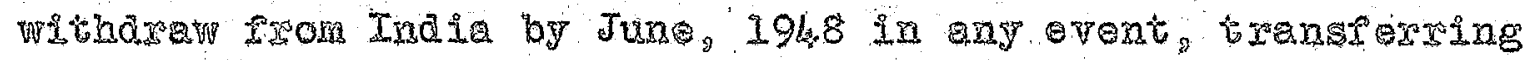
power preserably to one gorexment but not hesitating to tgansex. it to more than one goremnent it wach action prored vavoldable. on June 3, 4947 came the mounement of the plan por the partition of India into two independent Dominions, Indi and Pastan. The Indian princely states

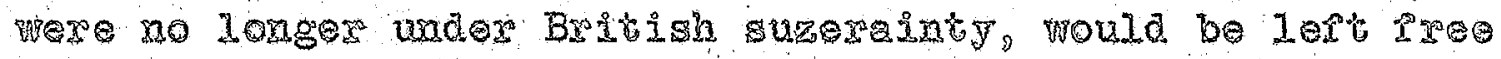
to acced to arther Domaion as they chose. Both the Cono gress and tho Mid teague acepted the plan.

An Indian Irdependenee Act was passed through the Bristsh Patiament and on the appointed day, Angus: 15. 1947, the British Irdian thpire ceased to be Despito the continue membership or both cowntries in the comonwealth ox Nations, 11 Indians hailed the and of the era of Birtish zule whah had begun some two centrirdes berore. The areation or the reta state of Rakitan symolizes the hopes and espixations of the 75 minion os its inhabo tants who, atter two centurles of onslarement, hare at last seon the darr of Ifberty. It has ensured ror them and for 


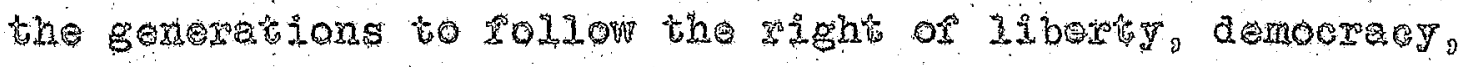

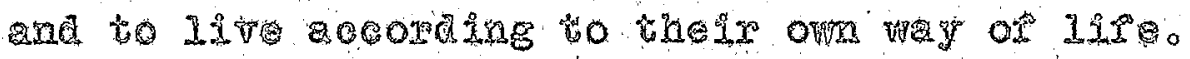

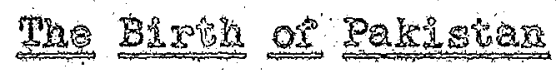

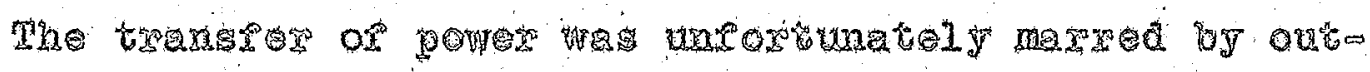

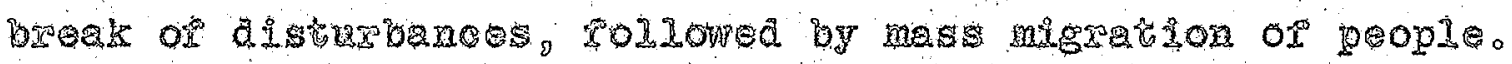

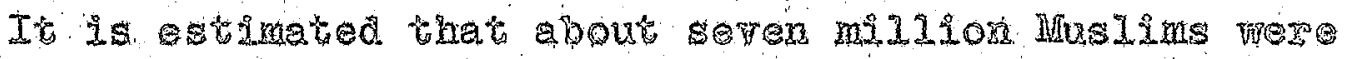

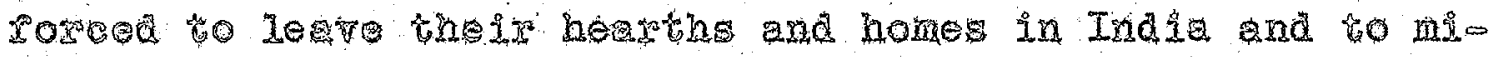

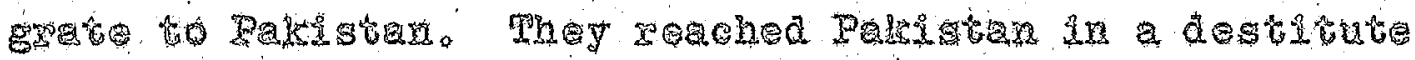

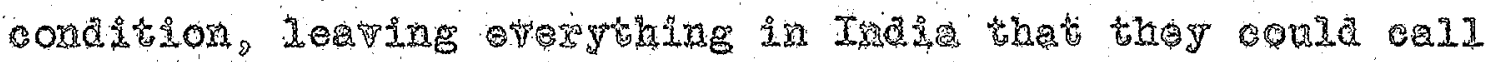

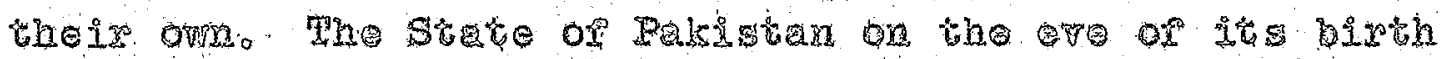

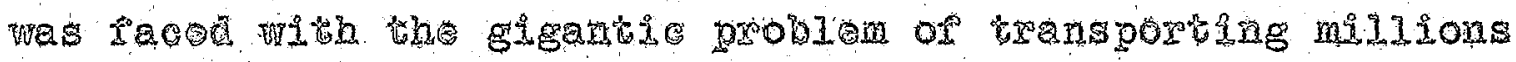

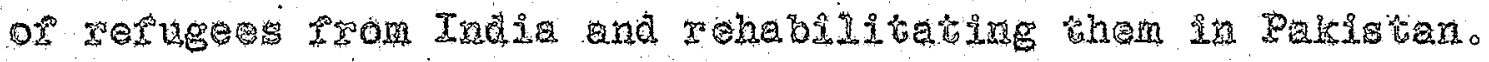

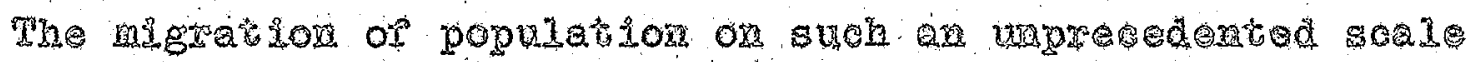

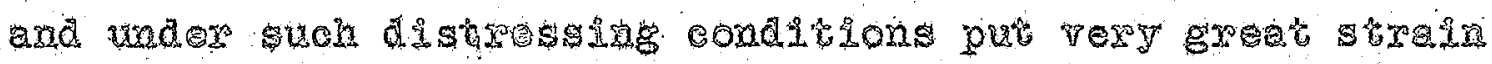
mon the econory of Pales surs.

The political rolations between the tow Domialons con tinued to morsen.

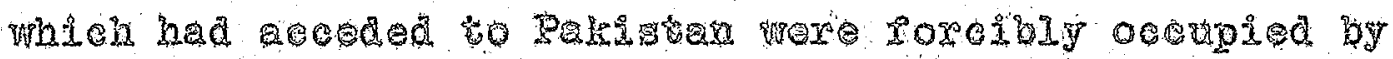

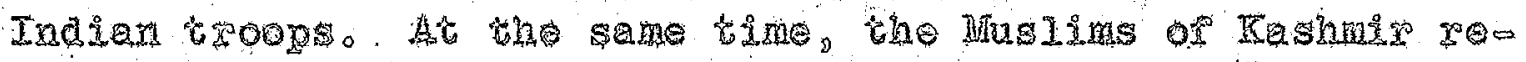

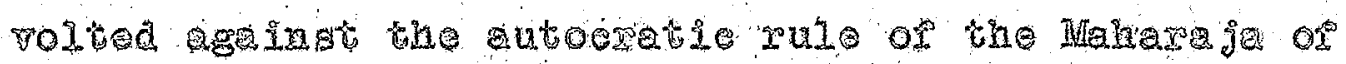

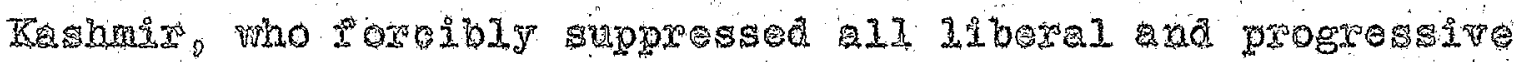
norements in his state and acoder to the Indian Doriaion

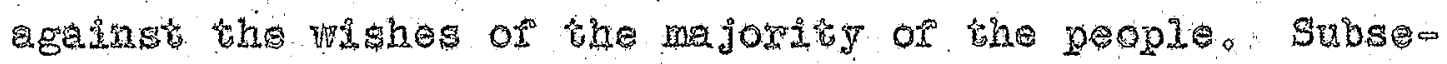

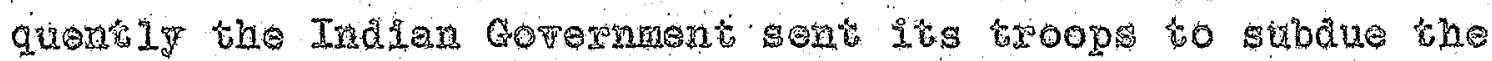

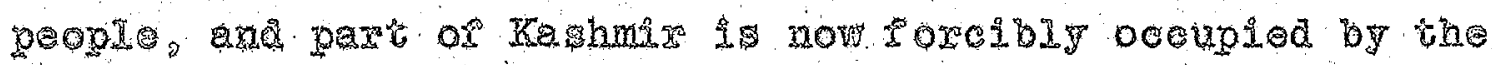

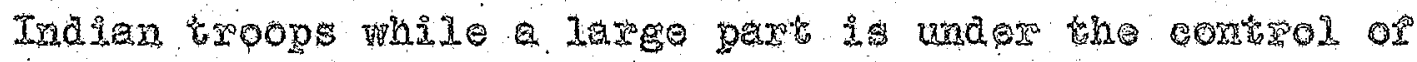




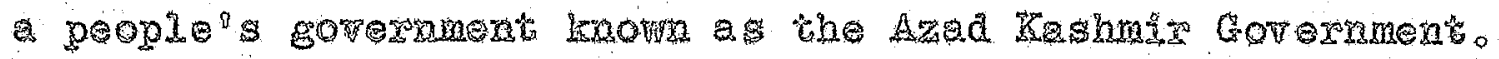
This disphe tha rerexed to the Unised Hatong, and it is gratifylig to note that as a result of the arorts of the

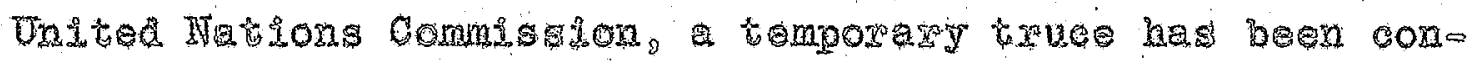

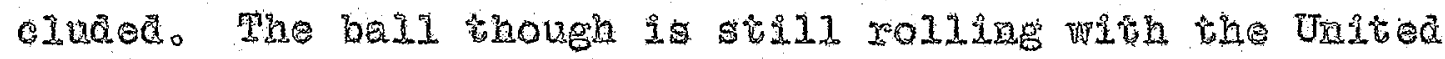

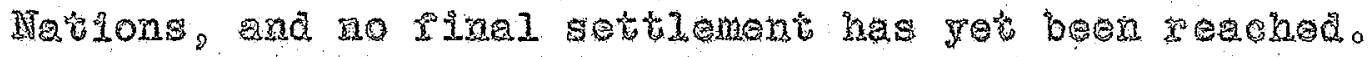

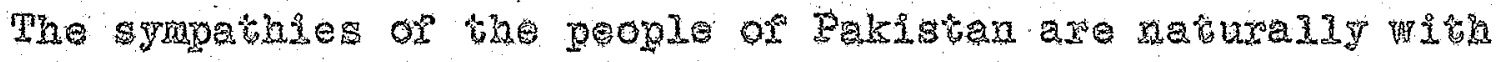

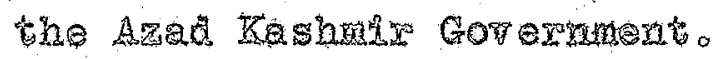

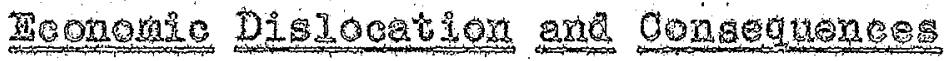

Word I Pakigtan subcontinent to a severe straino food wos insue

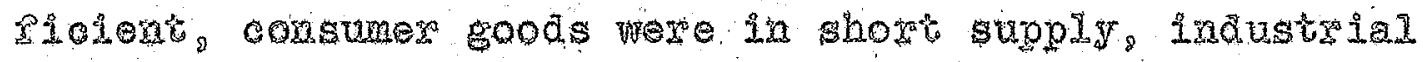

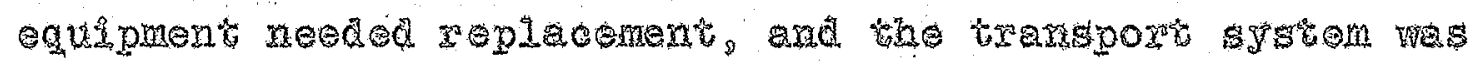
not ble to cope the the abomal conditions Due to hery

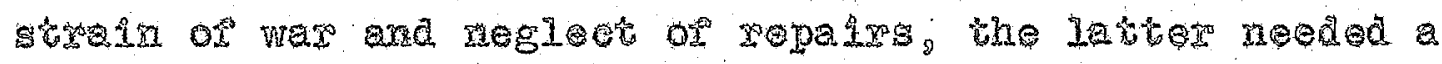
thorough orexhal. Produelon ot goods required ror the grosecturen of the last wa was to be wepleed by the proo ducton of good to met the meeds of peace and the requiro

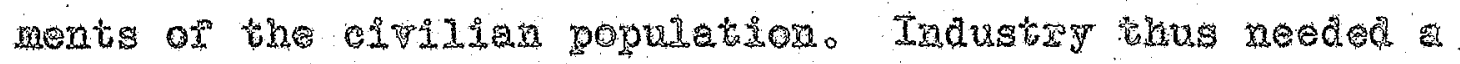

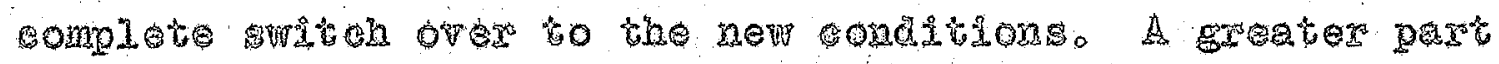

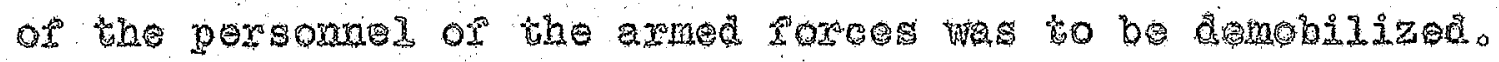

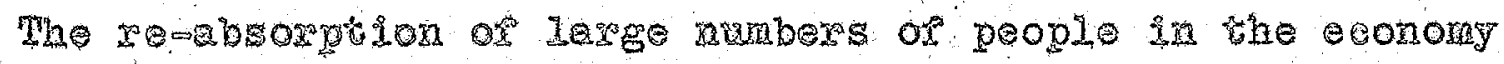

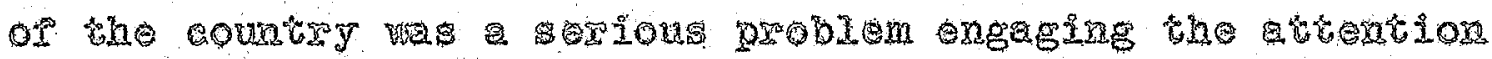
of the gorosomerto

Howerer, when eqonomie problems of sueh enormons tagen

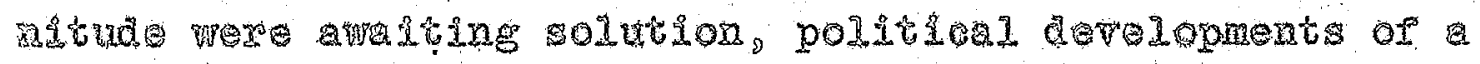




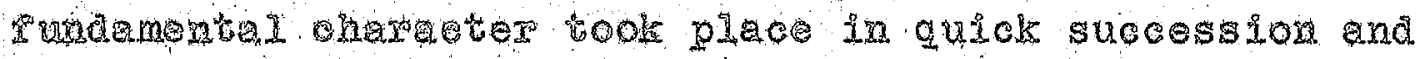
more or less completely monopolized the attention of the

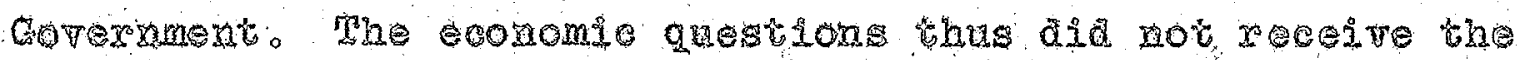
attenton whoh should hare been given to themo Shortage or 21 sorts of goods berane the order of the day. The toro mixation of the wat did not end the surearing of the people.

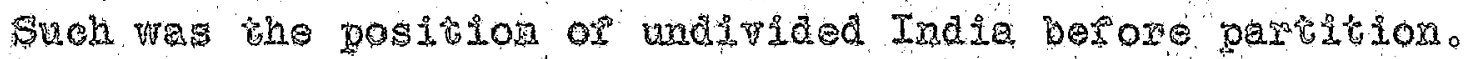

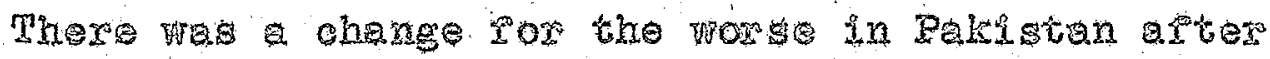

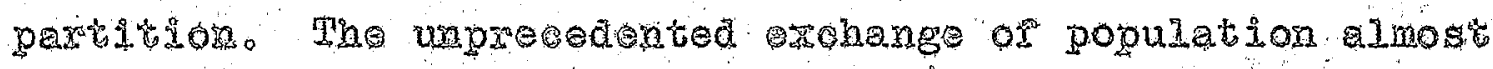

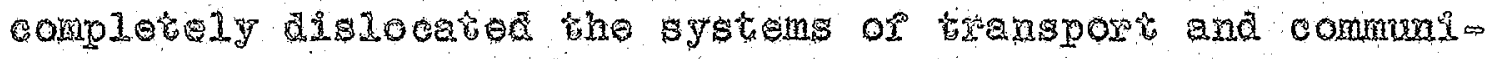

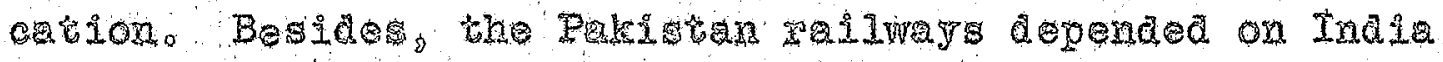
Tox the a

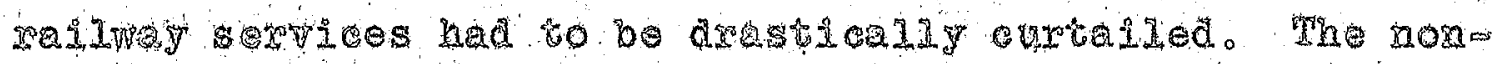

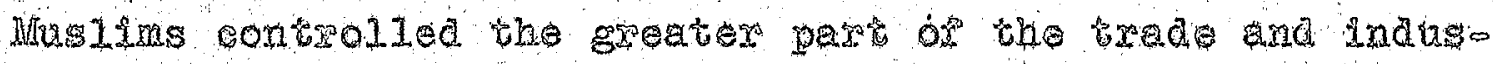

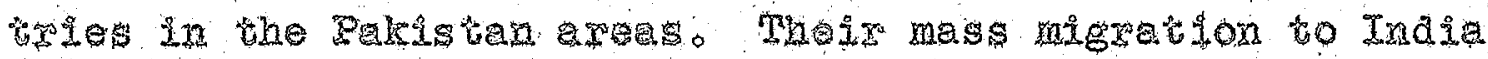

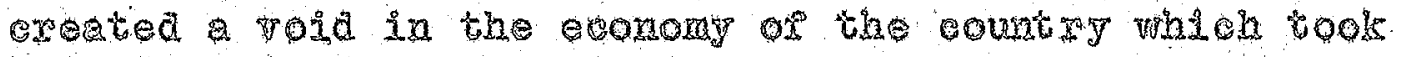
gone time to be rilted up. Whe banks in the are conprising

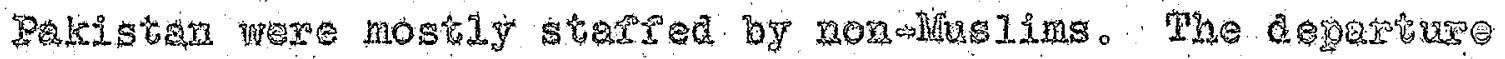

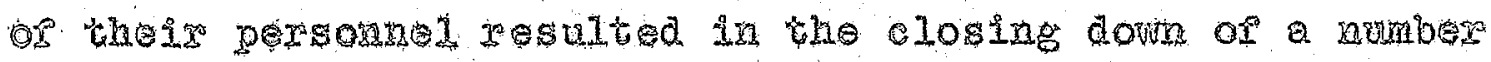

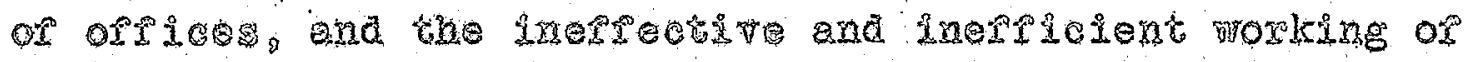

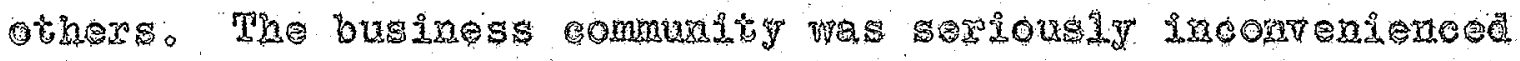

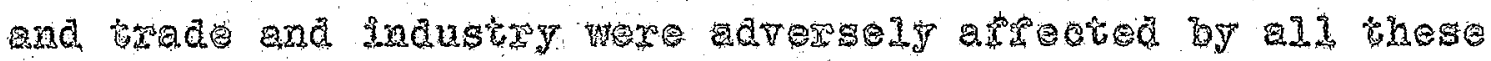

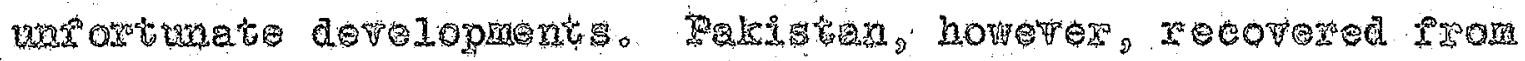

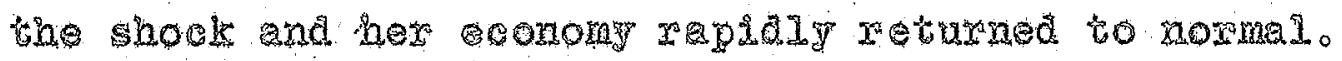




\section{Othes Derelopments}

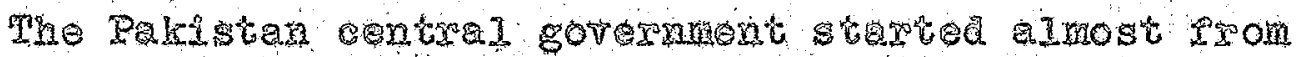

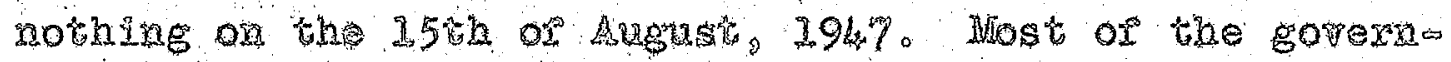

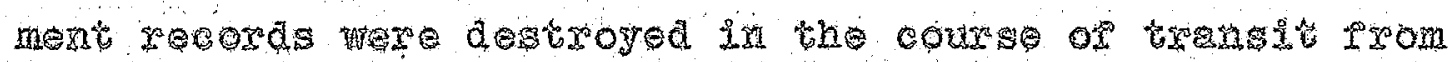

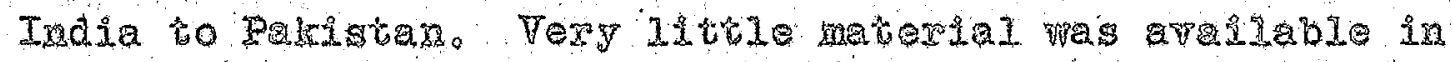

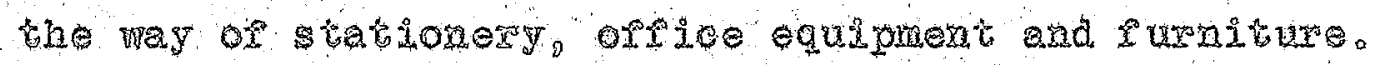
Som or the essental goverruent personel were detolued in

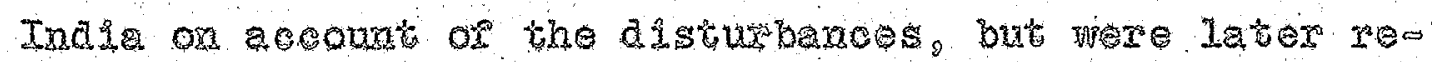

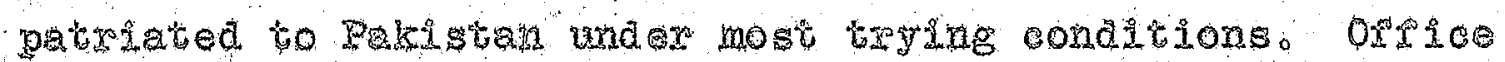
and esfontid accomodaton at Ka thi, the capital, wero inadequate. AI these ractors produced reperousions

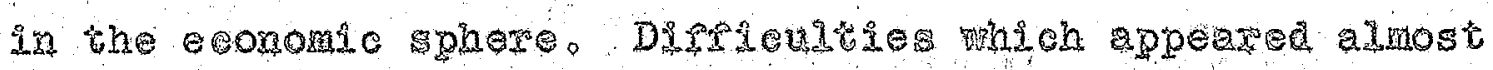

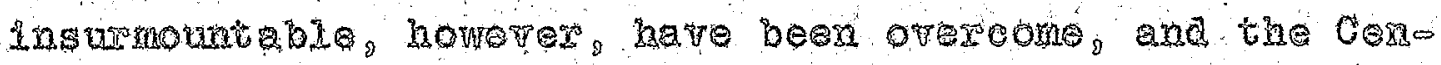

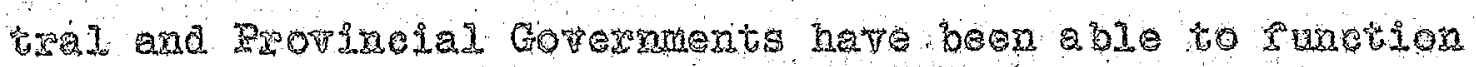
and taklo the lonumerable probems which confonted them. 
CHAPTIR II

FHXSOCRAFHTE HATORS AND NATERAC RESOURCHS

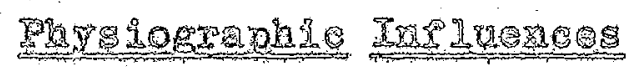

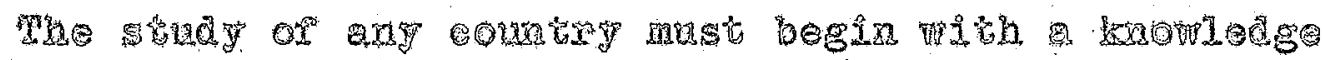

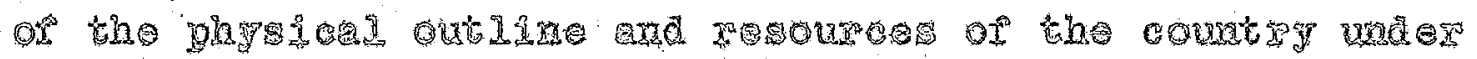

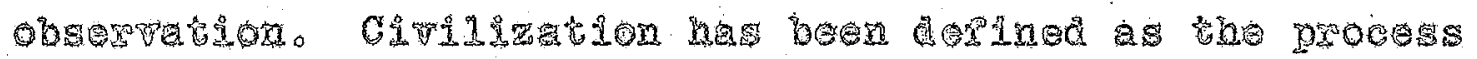

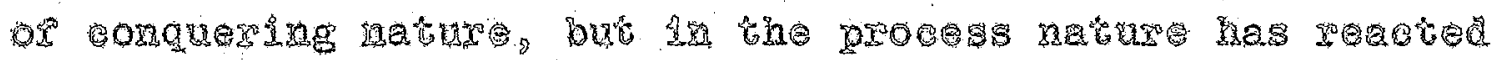

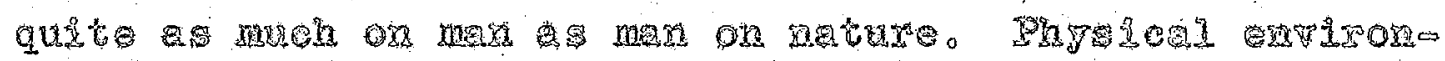

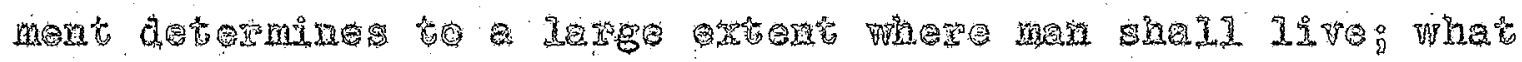

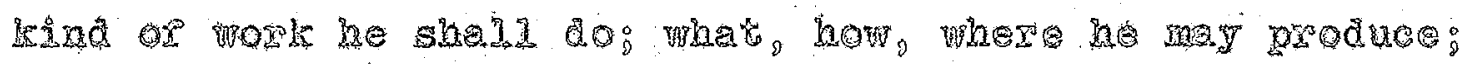
4.

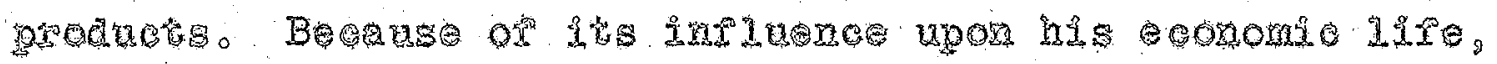

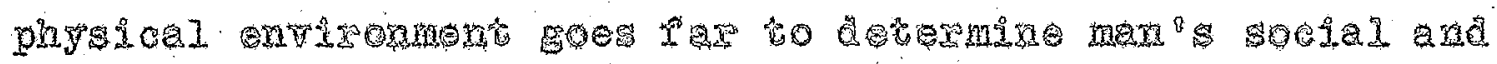

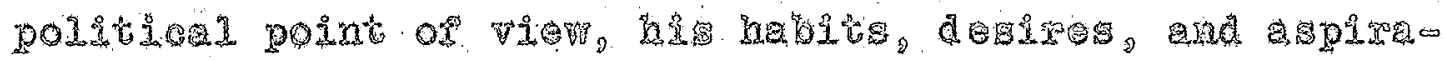
空主品。

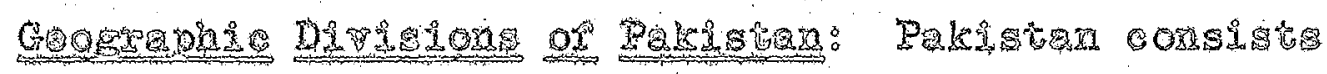

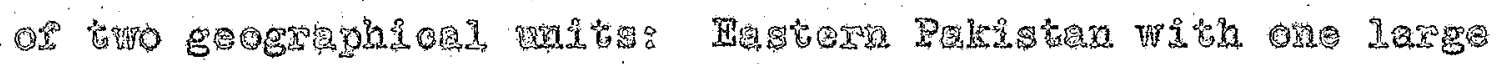

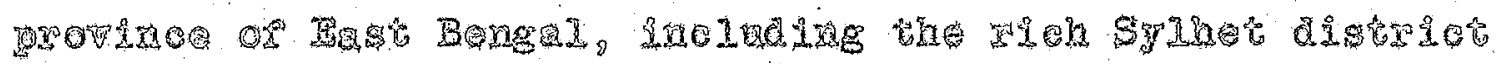

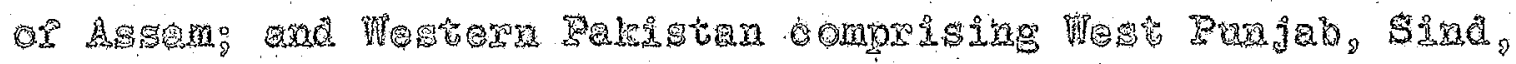

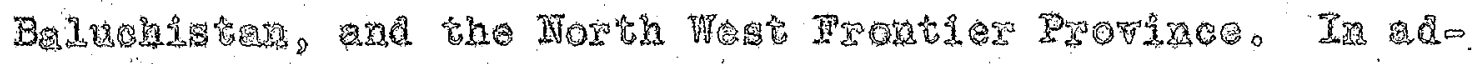

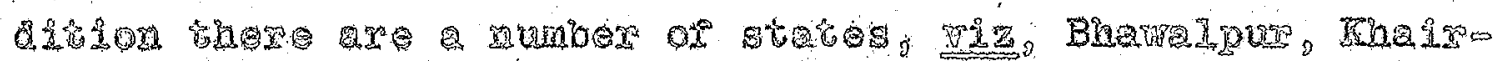

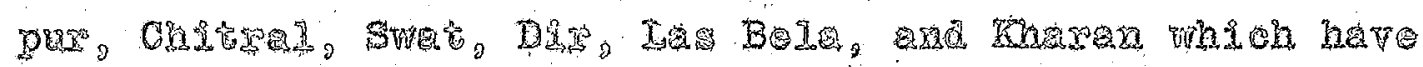

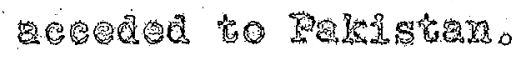




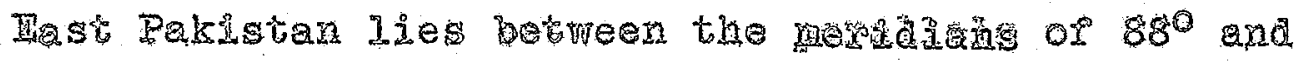

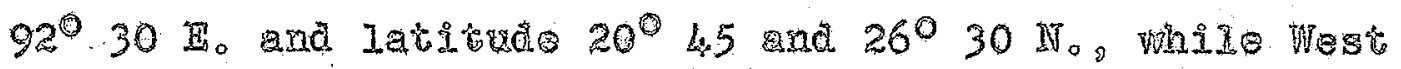

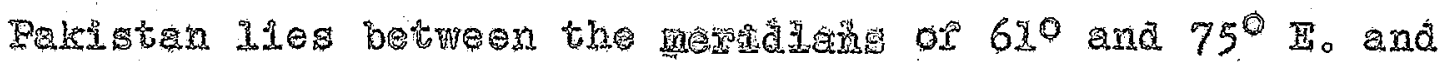
letitudes $24^{\circ}$ and $37^{\circ}$.

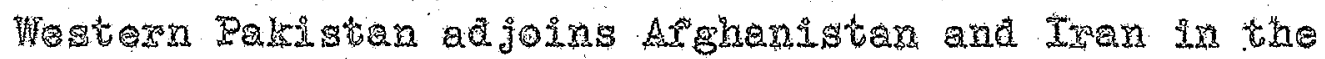

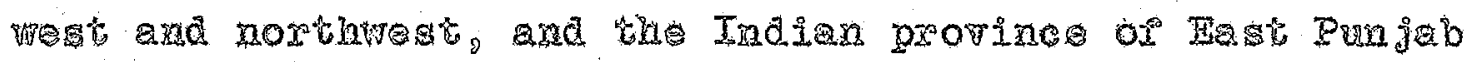
and the great Indian Dosert in the Hasto To the north lies the state of Jamain and Kashalr: to the south and southo west the Axabian Seq.

Past Bengl, the lasgest and most thiekly populated groritco of Rakistan, is separated from Westera Pakistan

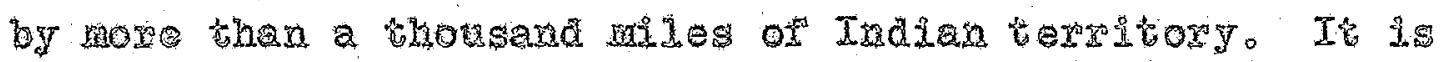

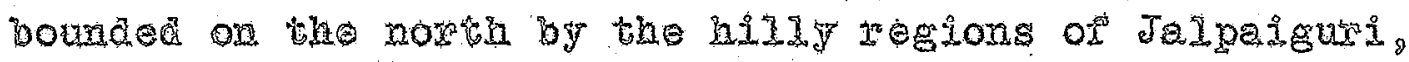
Darjealing, and perts of Assam; in the south the Bay of Bexgal; in the west by the Irdian protinoes of Wesc Bengal and Binar: and th the east by the Assam propines. Its

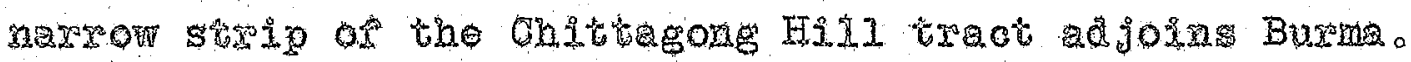

From its most northerly point to the sea codst in the south, Hestern Rukistan corrs a distane of neaxly 800 mies, wheren its rpesterm thp at Kllla Robet is separated trom the Indan bordar of about 700 miles. The entife area to the rotith ond west of the land is corered by great ranges of the Hindu Krsh and the Silaiman Mowatains rasing in places to a height of 14,000 rees. The salt gange and the arid plateas of that renge lie sighty toward the east of those mountain systems. To the south end soubhest of this region stretches a vat plain right to the Arabiar 
Sea

All the gxet five rivers or West Pakistan rase in the

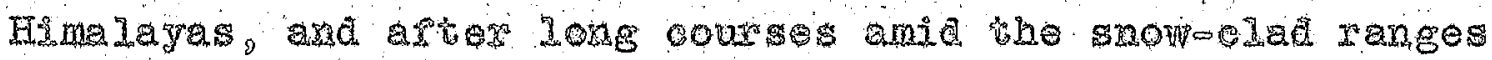
debach on the plains. The sope of the low countyy is to the south and southrest, and this dexmines the course or

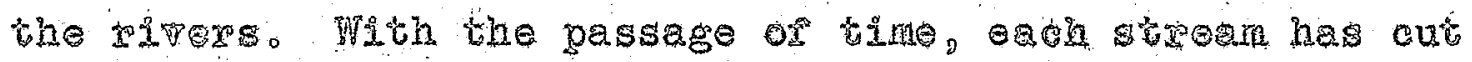
rox itsely a wide raley wich lies well below the level or the plain.

or these fite wion, the longest is the Indus.A

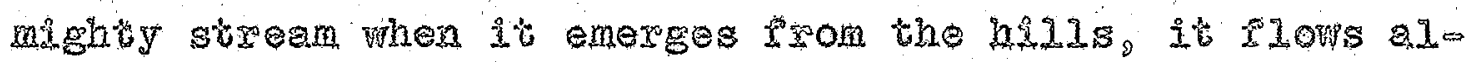
sost due south past Atrock, the oil distriet of Westan Bakistan, where it anters a deep gorge. It plows on through

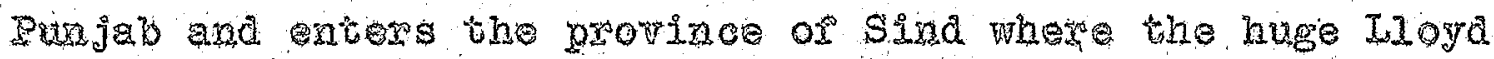
Barrage spans its weras.

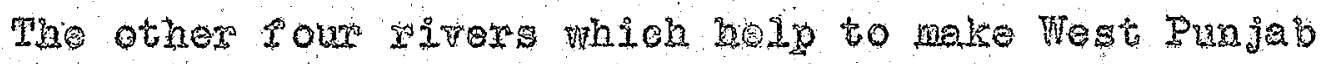
one of the richest wheat and cottonogxowing areas in Asia

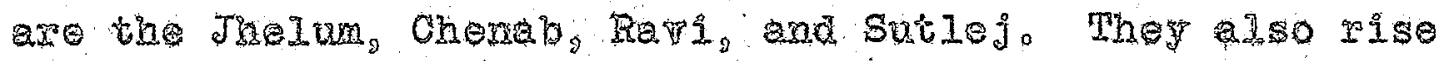
in the Hindays and atex thaversing the plans or the

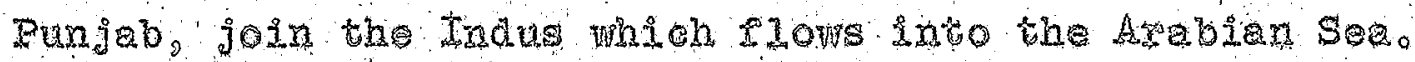

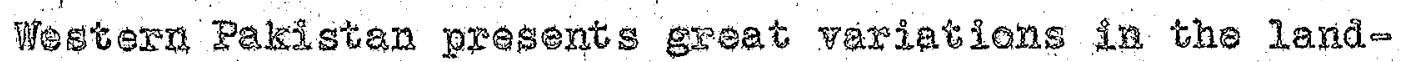

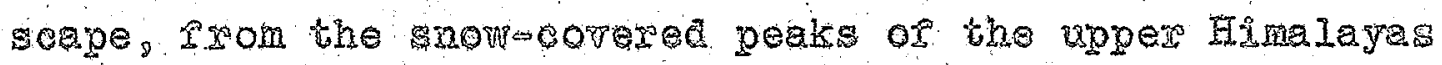
to the grey, somber desort or Sind. In the Noth West Fono ther Provine where the land on an areage lies more than 4,000 loet above sea Iore1, the senery is zugged. Ac

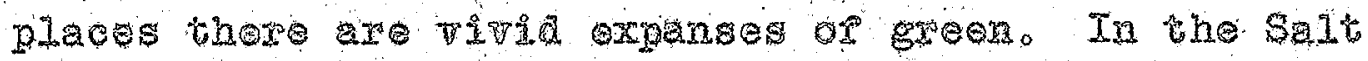
Range of the Frajeb the landseape ckes on a genten tono: the glopes are orten comered with grees box and hogmytie。 
But the toue bedut or the Pugab and sind lies in the plains.

In Baltohistan the gendral outlook resemoles that of the Iranian Plateat and, though sometimes oppressive in the

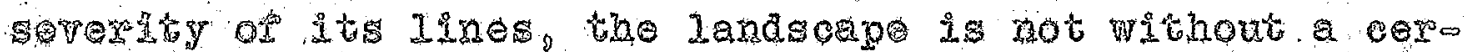

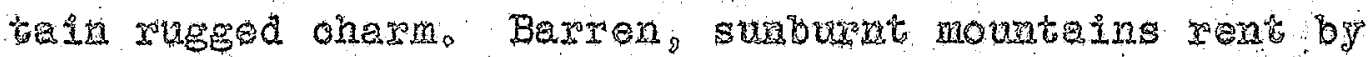
huge chasms and gorges alternato with arid deserts and stony

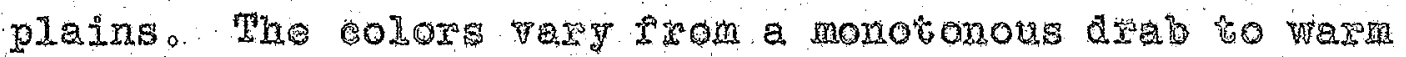

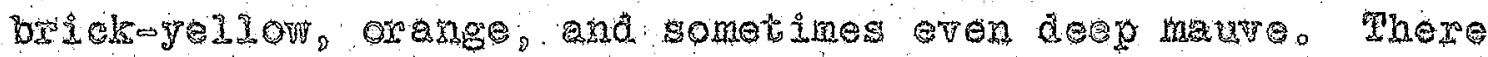

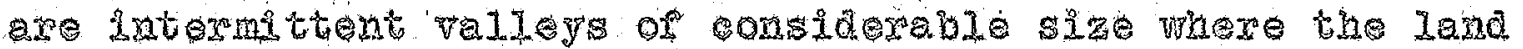

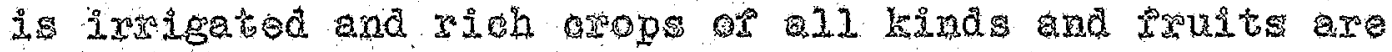

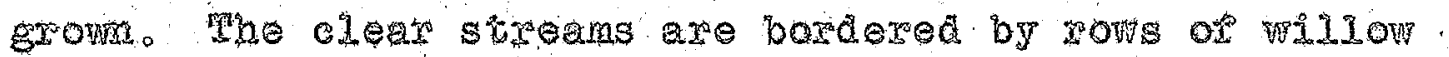

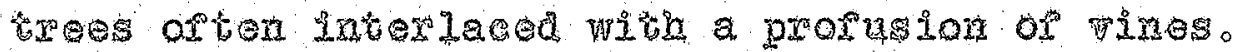

Tine ser cosstis ard and deroid or regetatjon, but there is a good harbor at Kargeni and nany ring, sandy

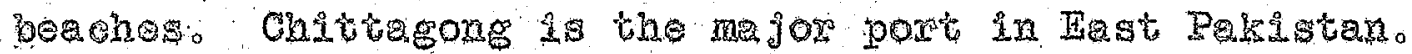

Hast Pakistar is a ros a llurial plain with hardy hill or eren a rook plsiole por miles: Daly on the southo eqsten fronter a suecession or low monthin gages covers

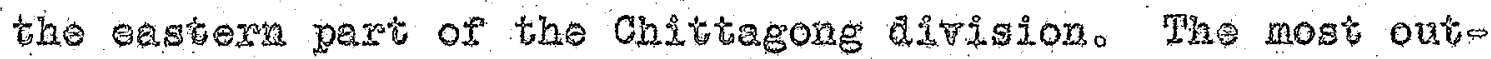

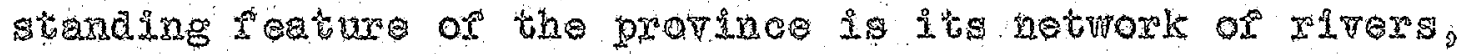

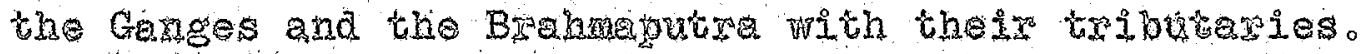

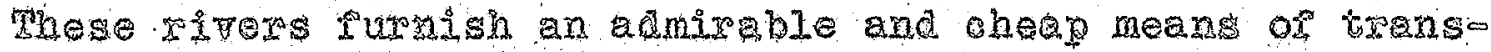
port: they contain ax inexhausible supply or sish and

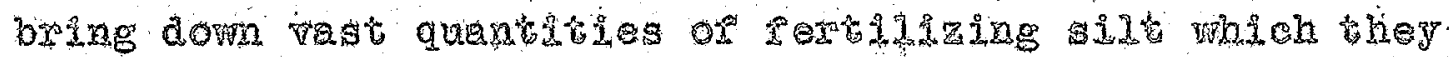
deposto orer the surface or the land. the dense rorests 


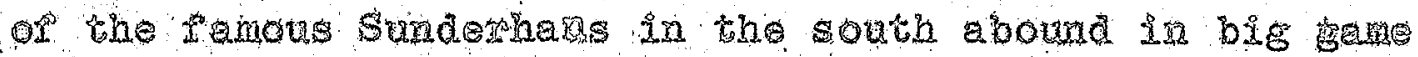

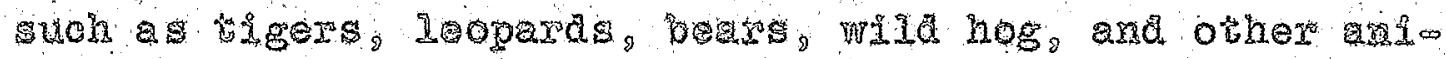
mas:

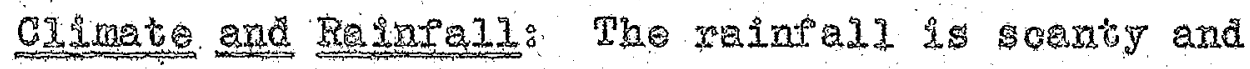

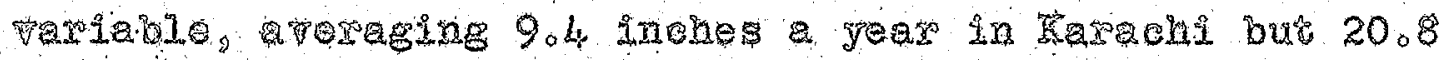
Inohes in tahore. The temperatue of the inlard plains is

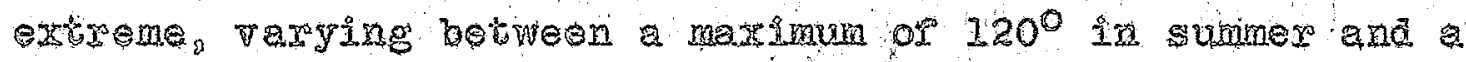
minitur of 280 in whter nights。 Hesern Pakistan has a

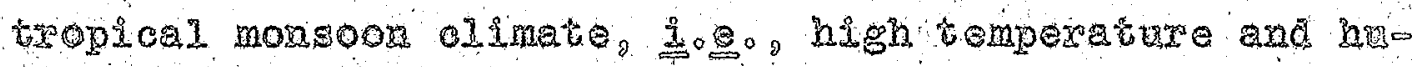
midisy, and a dyy season poltowing heary tanso the solino pll a Sylhet, and the temperature from between $45^{\circ}$ in winter to $102^{\circ}$ in momero.

A climate ratorale to the papd developrent os ma

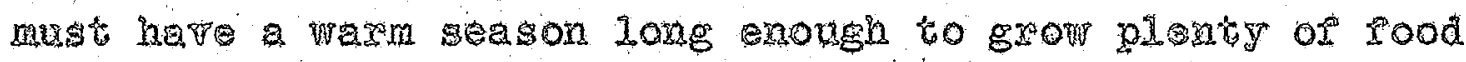
ard cold season to make men work no lay up surplus sood:

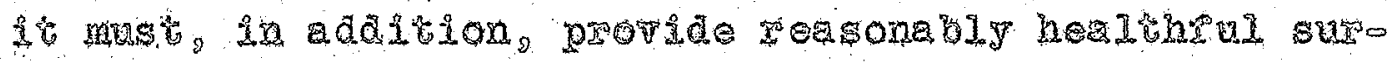

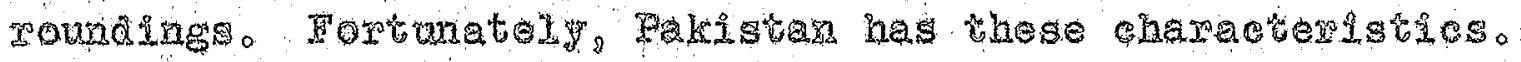
These oxtremes of temperature have bred a people remakably hardy and ropous, exdowed whin good physidue and great

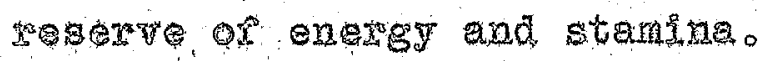

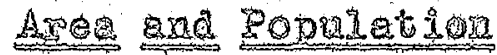

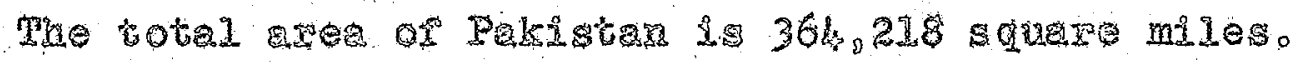

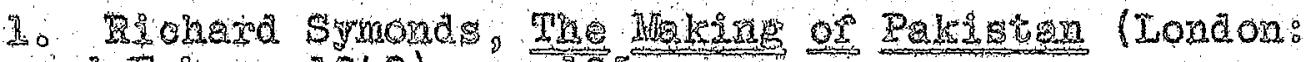
Fabor and Faler, 1949), po $205 \%$ 
West pakistan has an area of 310,298 square miles mereas East Pakistan has an area of 53,920 square miles。 The total aree Ia distributed as pollows:

\begin{tabular}{|c|c|}
\hline Hast Pakistan & 53,920 square miles \\
\hline The Punją. & 62,000 \\
\hline Baluchistan & 54,460 \\
\hline sind & $48,14,0$ \\
\hline $\begin{array}{l}\text { North West Frontiex } \\
\text { Porince }\end{array}$ & 14,260 \\
\hline Baluchistan states & $79,500^{\circ}$ \\
\hline Bhama Ipus stato & 37,500 \\
\hline $\begin{array}{l}\text { Norch West Frontiex } \\
\text { Province states }\end{array}$ & 25,000 \\
\hline Khaixpur state & 6,000 \\
\hline Junagadh state & $3,4,38$ \\
\hline Total & $364.218 \mathrm{square}$ mile \\
\hline
\end{tabular}

Pakistan's population, according to the 1951 census, is 75,687,000, These rigures, however, are based on a preo Iininary count and are subject to retigion.

The total male population of the country is $40,090,000$ and the folma poptation $35,597,000$

The percentage or Iiterate persons is $13.2:$ the total number of literates is $9,978,000$.

1. Basie Facts about Pakistan (Karachi: Government or Pakistan 1950) po6。

2. Pakistan Arfalye (Washington, DoCo: Pmbassy or

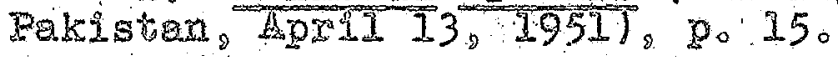




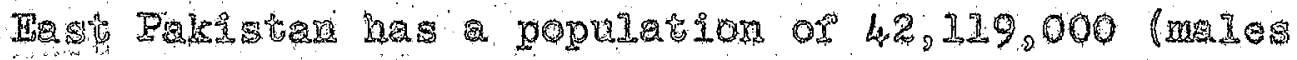

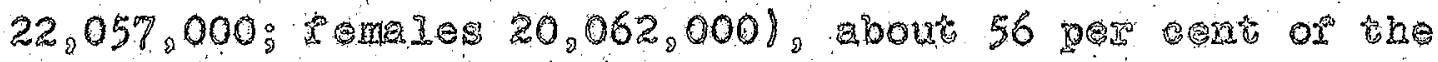
total popadator ox the goratry.

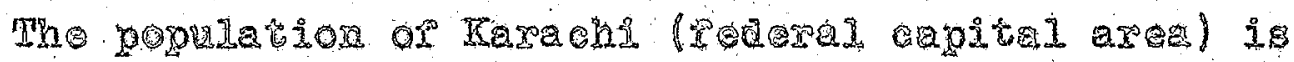

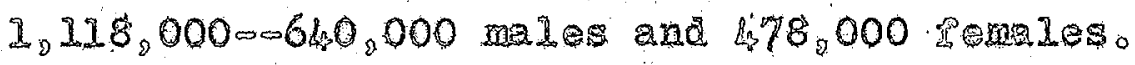

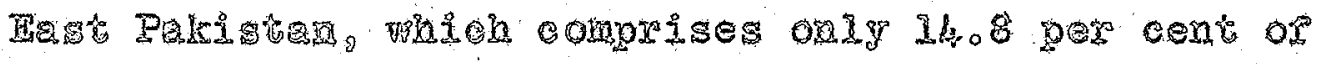

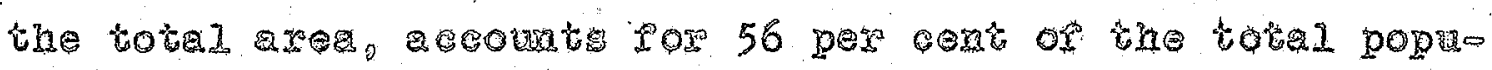
IQtion of the ountry. The density or population in Bast

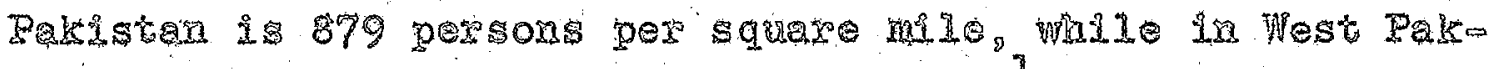
istar it is 133 persons per squar mis.

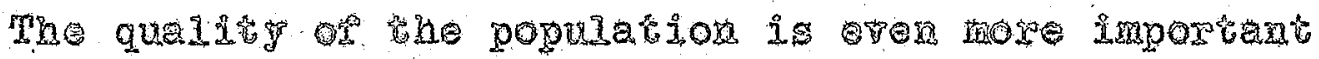
than nere numbers. So pax a the strengh of the body.

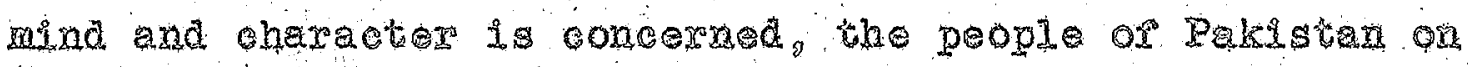

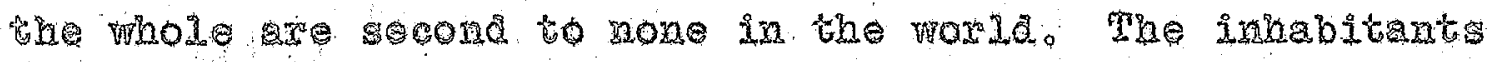

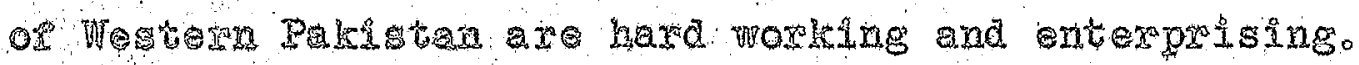

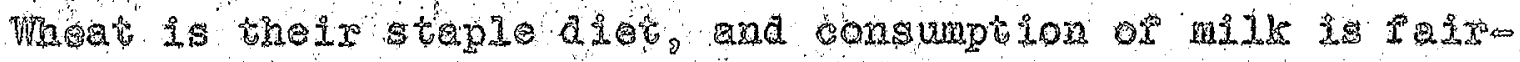

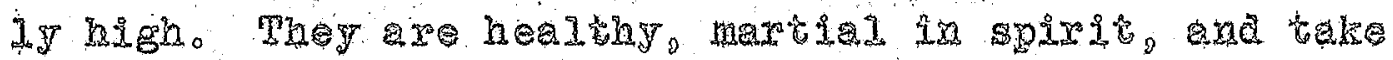

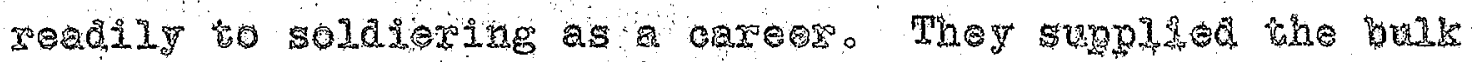
of the recruts to the arny of wnd thided India, and hate Iort their nars in the various bettelields of the word. Thet make excliext astsans and cratsmen besides being good agpioulturisto The pople of Hastern Pakistan aro

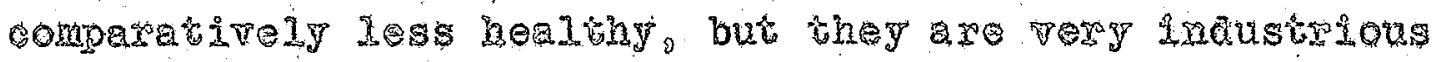

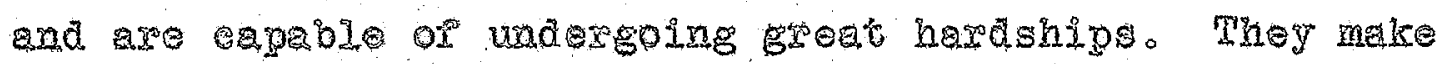

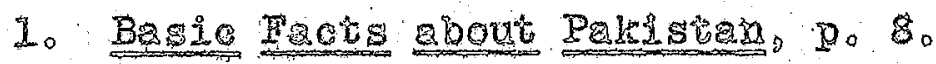


escellext somerno

\section{Natura 1 Resougees}

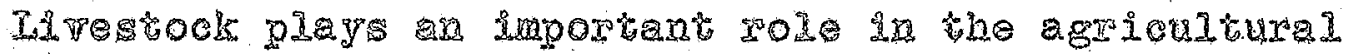
conony of Paxistan. Mfehanized gexiculture being waknowa, livestogk is practipally the only source or pover. aralible

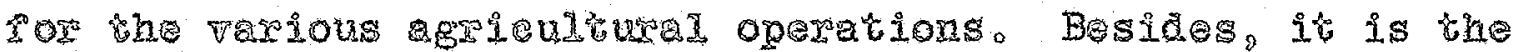
souree of wilk and mik products, meat, hides and skins, tool,

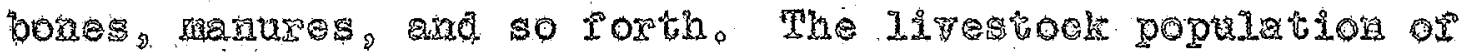
Pakistan is given in the pollowing tablo

\section{TRISI $I$}

IIVISPOCK POFOLARTOX (IX) Wilions)

\begin{tabular}{|c|c|c|c|}
\hline And 1 & Sumbes & And 1 & Wurabers \\
\hline 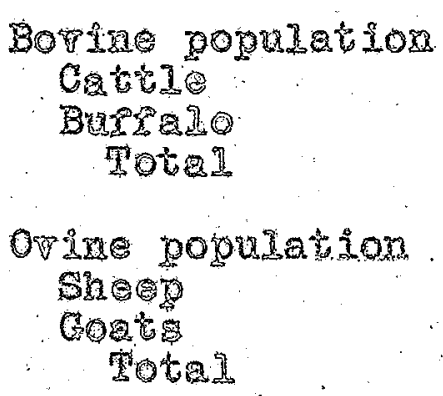 & $\begin{array}{r}3500 \\
500 \\
3000\end{array}$ & $\begin{array}{l}\text { Hoxsos and ponies } \\
\text { Hules and donkeys } \\
\text { Camels } \\
\text { Poultry }\end{array}$ & $\begin{array}{l}0.6 \\
1.3 \\
0.4 \\
27.3\end{array}$ \\
\hline
\end{tabular}

The male-populaton of the ox and butralo is the soure or pow and the fenate population 288.

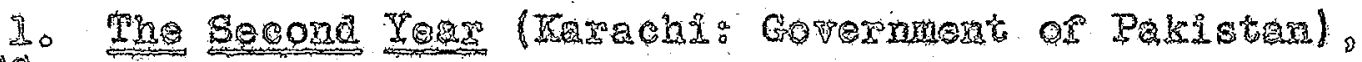




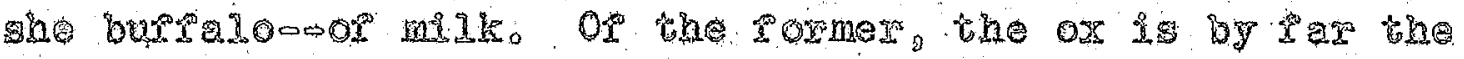

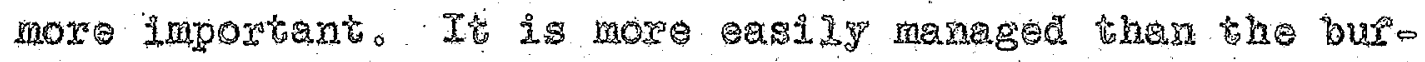

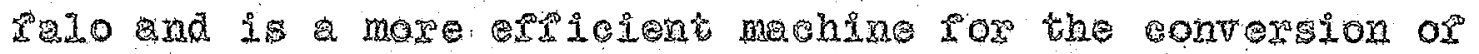

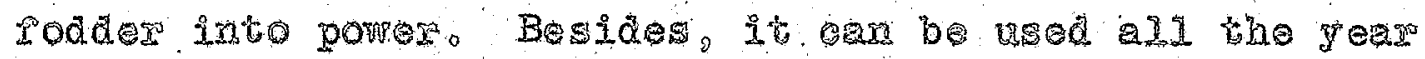
round, whers arralo canot be used in bot meather.

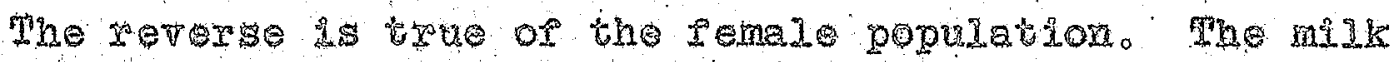
gield of the sho bupralo is meh groater than that of the con and is a more exicient molno then the cow tor the oontersion of fodder into tik.

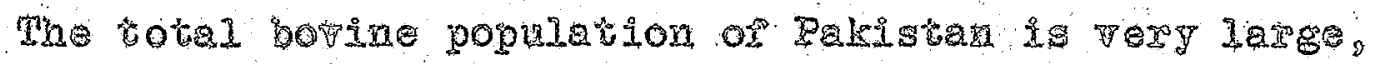

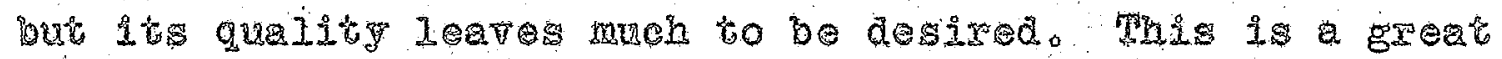

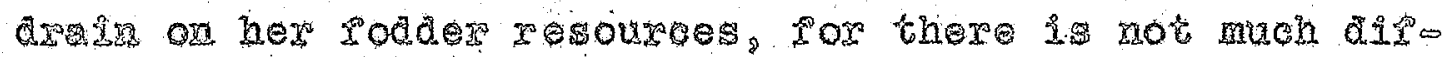
setene in the consumption of fodder by the cat 10 whatever

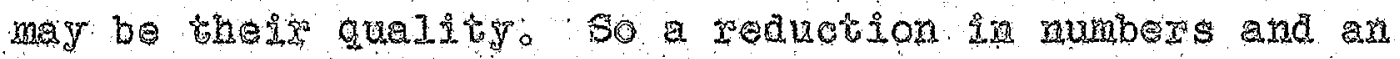

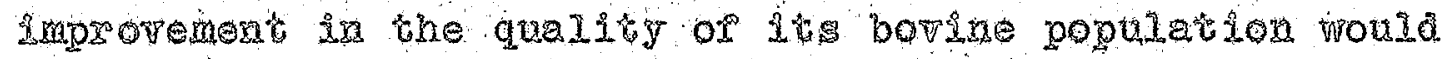
be pery weh to the adrantage or Pakstan dororts are being rae to improve the qualty of aninals through betrer

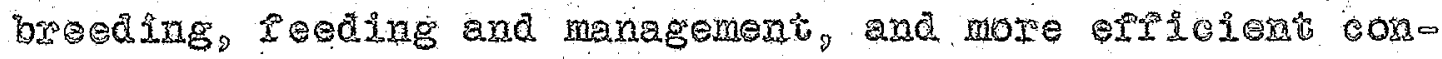
troj or disease.

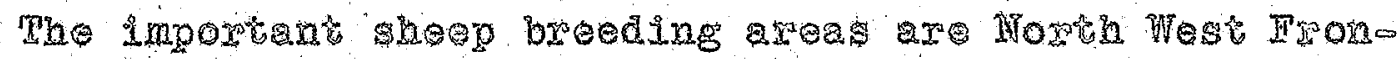

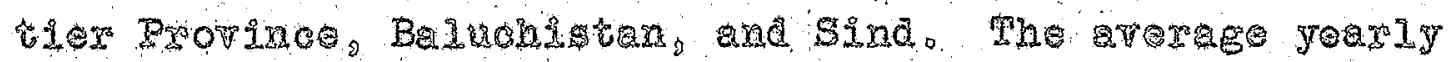

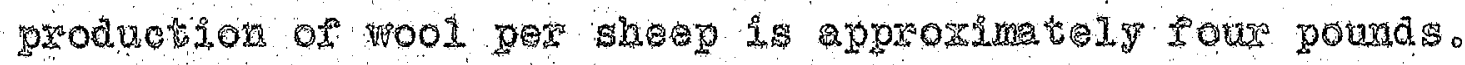
Sheep a kept xor aud purposes, mutcon and wool.

The man wility of gores ijes in the production of haip, skin, and mer. some braeds are good milkexs and are being preserved as the poom man's covo

The rumber or horses, ponies, mules, donkeys, and 
cameis is not wery large. This is so bacause ozen aro used

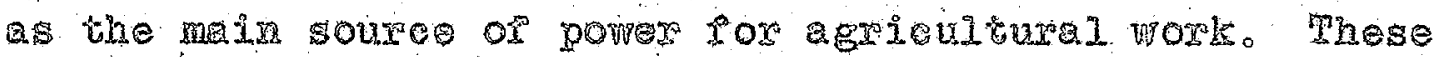

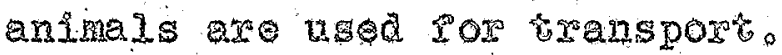

Roultry resouces are enorimous, but they are not ver produetive. Replaconent of the indigenous stock with surtable toreign breds is being encouraged.

Fisheries: Fishexies in Pakistax fall into three mein

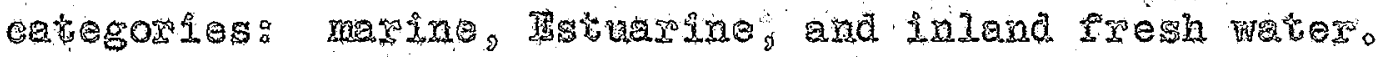
The provinees of Hast Beaga , Sind and Baluchigtan have aco

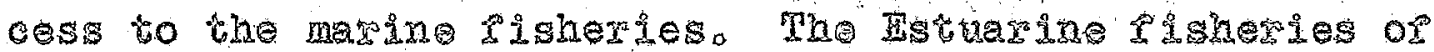
the Gangetie Doled of the Surdegans and of the Indug Dedta

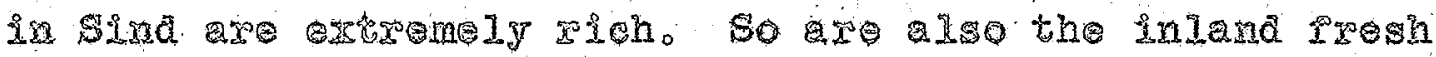
Watex fisheries.

Tastern Pakigtan ham been endowed by nature whin exo Geptonaly abudan resoryces in respect to risheries. Tish is an inportant axicle or diet of the population in this are, and lage quatities are locally consued. The 5urplus is axported。

The gorernments of East Bengal and sind axe attaching great importance to the develophent of their isheries or scientific linos, ano both hare wellooxganized Departanen

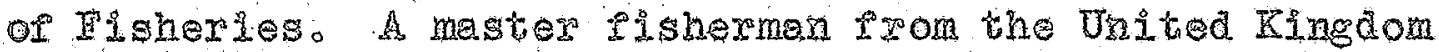
has been exgaged to give demonstrations on modern methods of rishingo

A seheme for the construction or a new pish hasbor at Karach has been appored in promelple a pist sto

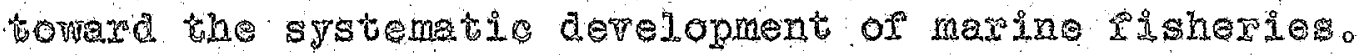


This haror is intended bo provide all modorn sacilitias

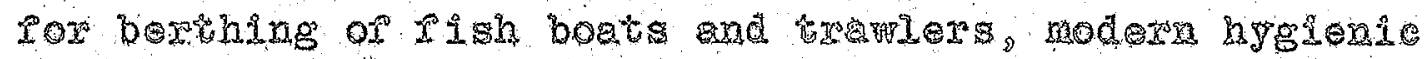

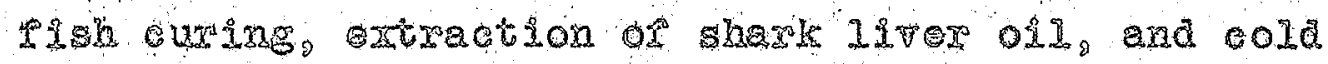
storage arpargenents.

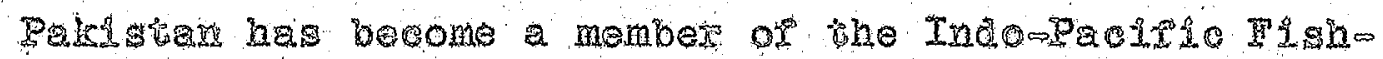

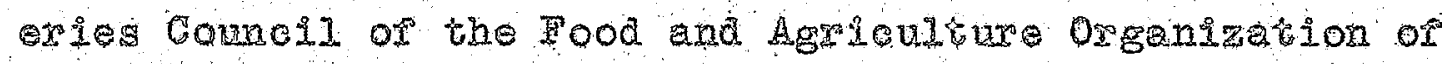

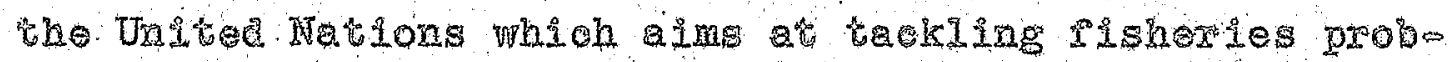
Iens of the Indo Paciri region on a collocive and cooperan tive basis.

Torestr: Torests play an linotont pole in the ocono

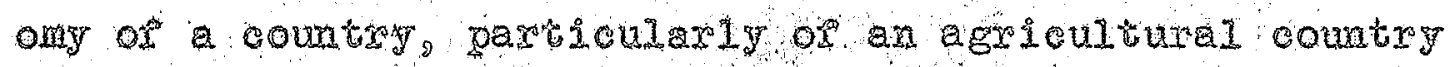
1ike Eakitan. Wher aro essential on physcal and olmato grounds, tor they tendex the linate note equale, prevent araporaton and tend to increase the precipitation on noisture. They xadue loods, pender the plow of water in roers more contruous, and prevent soil erosiono. Besidas

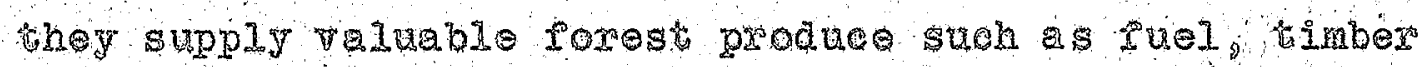

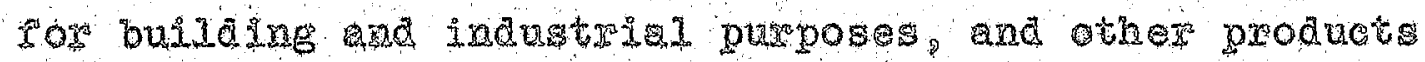

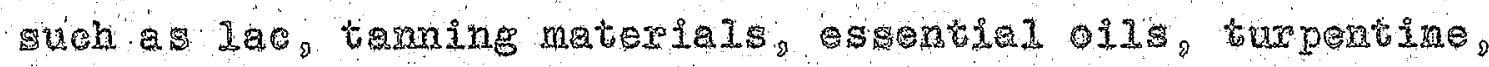
zesin and portho

The ora wder soresta and pexcentage to total axea

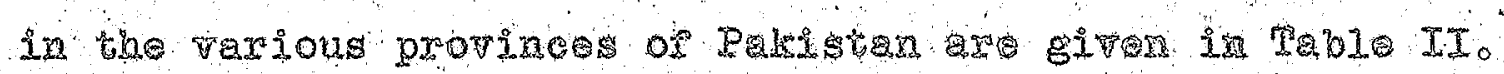

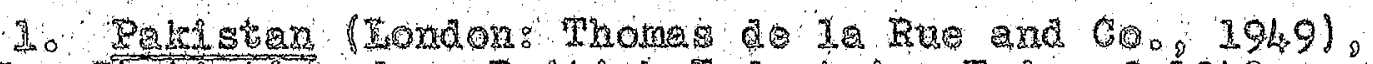

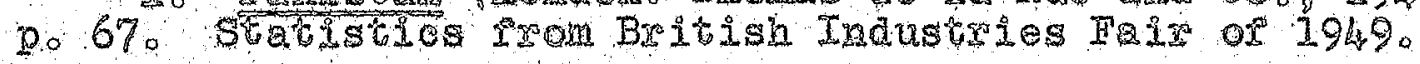




\section{MEBTISIT}

CHASS THICATSON OF TOEEST ARHAS

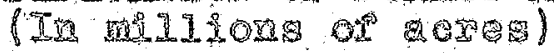

\begin{tabular}{|c|c|c|c|}
\hline 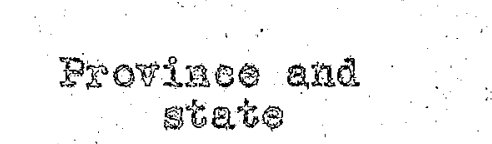 & 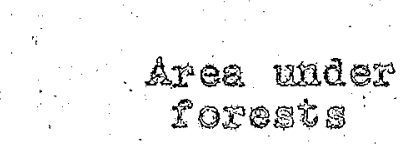 & TOEA & 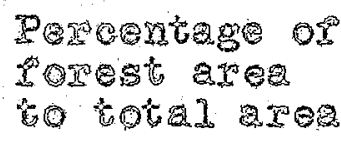 \\
\hline 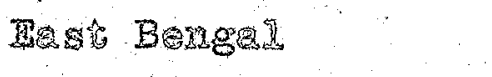 & 3.0 & 29.8 & 10.0 \\
\hline Sylaes (Digin) & 0.2 & 32 & 6.6 \\
\hline 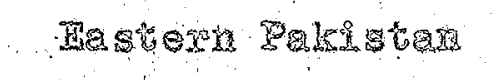 & 3.2 & 3209 & 9.7 \\
\hline 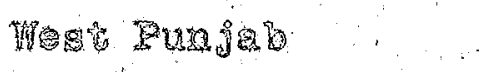 & 1.2 & $3 \% .2$ & 3.02 \\
\hline 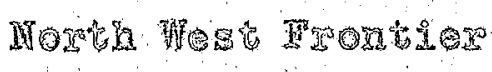 & Providego & 8.7 & \&oks \\
\hline $8+5$ & 0.9 & 30,1 & 2.3 \\
\hline Basueristan & dod & 340 & 302 \\
\hline 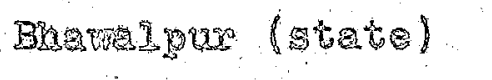 & $\stackrel{8}{\square}$ & 4.6 & O.t \\
\hline 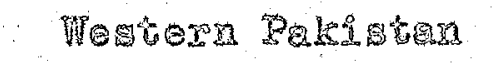 & $30 k$ & 11504 & 209 \\
\hline Totad PaL stor & 6.6 & $14.8 \%$ & A. 5 \\
\hline
\end{tabular}

The most atring teature of the a ve pigures is the

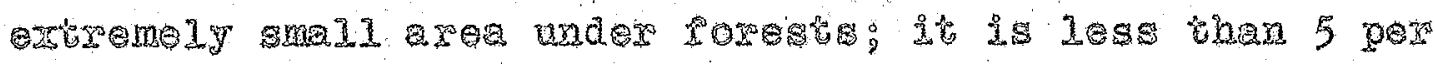

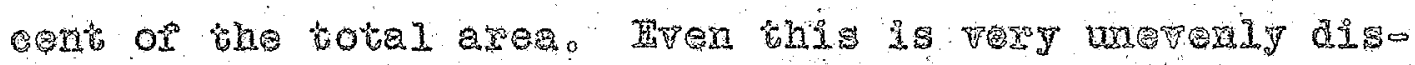

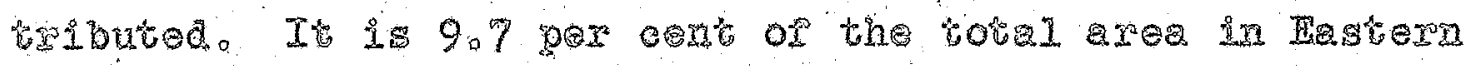

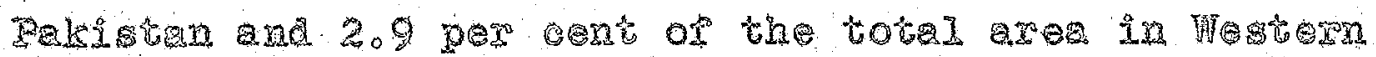

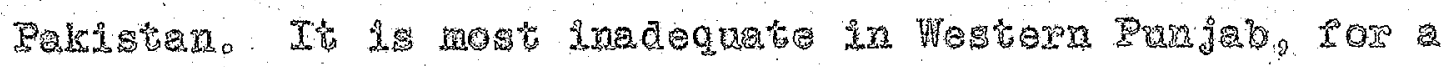

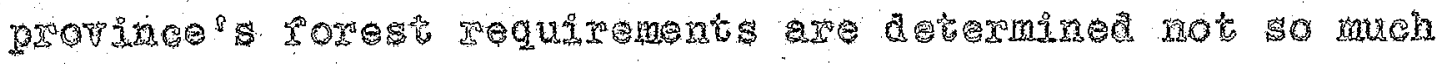


by fits total area as by the size of its populition whose needs have to be catered to.

West Pujab with a population of about 20 milions has a Porest area of 1.2 million aeres. The position of Sind and North Wost Frontier Protinee is slightiy betrer in thim xespect. The population of Sind is about onearourth that of West Runjab, but the fosest area of the propines is more than halr thet of West Punjeb. Similariy, the population of Horth West Frontier Province is Iass that oneosith that or West Punjab but its rorest area im one thind that of Nest Puxjab.

Insureiciency or roxegts is proving vexy tharmul to

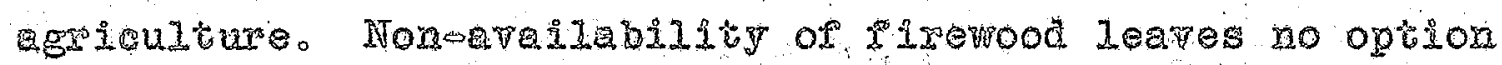
sox the cultivator but to burn cow dung, which is much more rajuable as a manure than as a tuel.

In tast of the advand countries the rorest area is maintined at a bout 25 per cent of the total area. This is considered necessary to meet the requirements in respect to forest prodice. Approximately the same pereentage of torest area should be necossary por Pakistan, particulariy atrez a decade ox so, oy which the she musti have achierved sore theasure of economic development. The goternment of Pakiso tan is paying attention to the forest research and increaso ing the area vader porests. 
CHAPIER ITI

\section{AGRICUTPURP}

\section{Lise in Yillages}

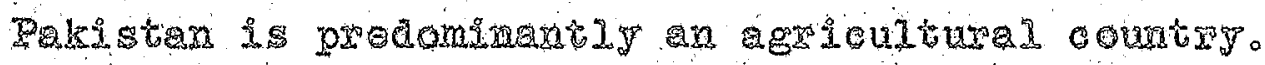

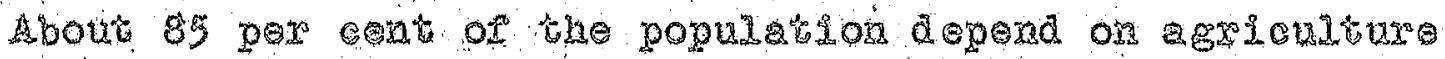

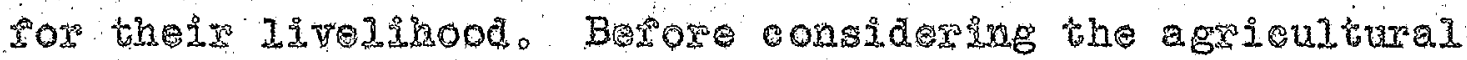
resoures of Rakigtan it would be or some interest to glance into the rilage Ilte where this 85 per cent of tho population 1ive.

The comong of the arerage peasant"s home in West Fun jab and Sind are diotrted by his limited means. Built of mud with a rlat roor and shorn of embelishments and decoration, his home is coolex in sumer and wamex in with cor then a house built of cement, briek, or stone. The

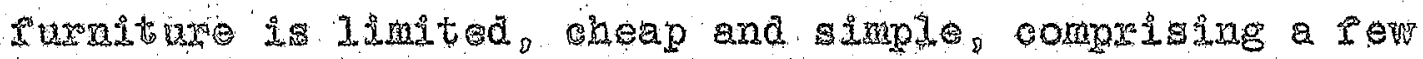
metted bedstads, stools, and in rexy to cases. a rew charis.

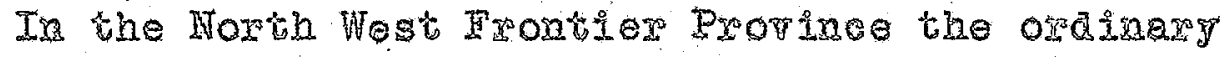
pasant lives in aingle roon bout 25 by 12 pes, built

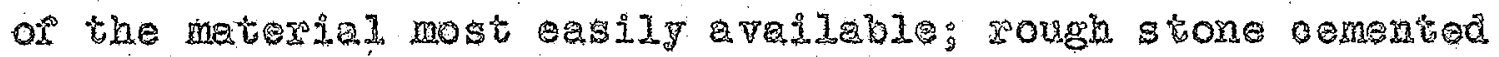
with mud is used with coasse slate tot the roor. Eyexg TIlage has its guest house mantained by the headman or a 
Sew leading villagers. This iq also used as the rillage elub were people sit and chat only.

In the villages of Hest Pakistan ach house stends on 1ts path of homestead Iand wheh is planted with fruit and palm treas, afrording protection from the heat of the sun. The sites are laboxioushy rased by xiluing them with earch. The houses are exected on mod plinths, built around

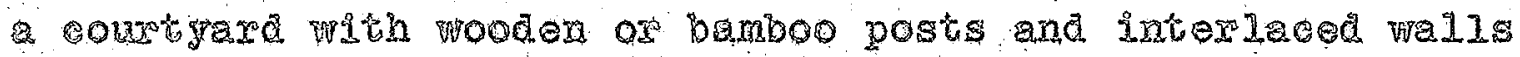
or aplit buboo, wht the attached goors yesting on a but

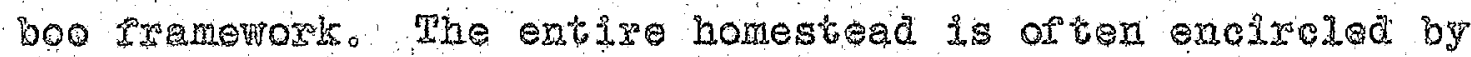
a rencing ox by ind genous hedges.

The joxity of the people live in villages. The tili lages are interconneced with one anothex and their rem

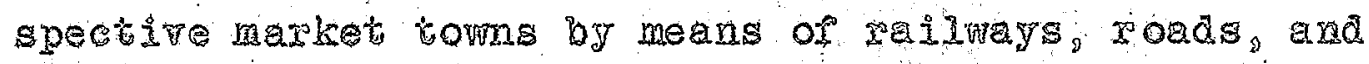
trails. The usuel mode or travel and havage in the vilo lages is by means of the bullock cart and pack rales and.

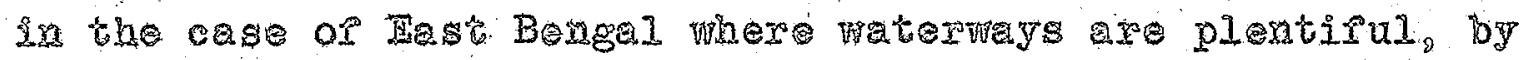
boat.

An avarage village bas anywere between 100 and 2,000 Lnobitants. It is generaliy buile in the center of the agrievitural Iand lite in the rilage is thoroughy simo ple, democratis, and commal. Most of the loeal disputes are settled by the village asseribly or alders. Government manineryy intexpenes only in cases of breach or geace ore for revenue settlement or allocation. Evexy large viliage has priday school, post opriee, police station, and 2 small dispensarty. Smaller villages are grouped together. 
tions:

Hoste ot the inhabltants or pillages are agaged in

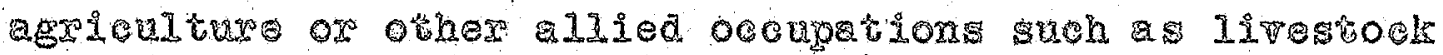

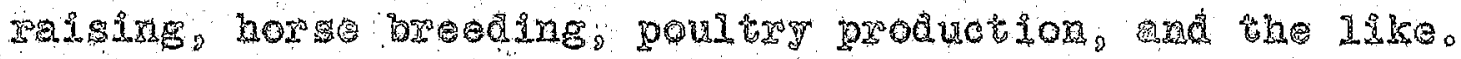

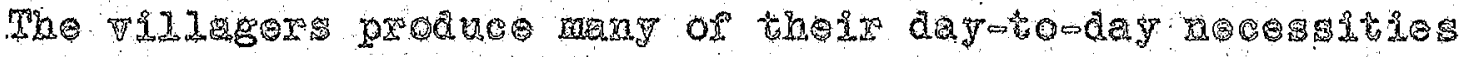

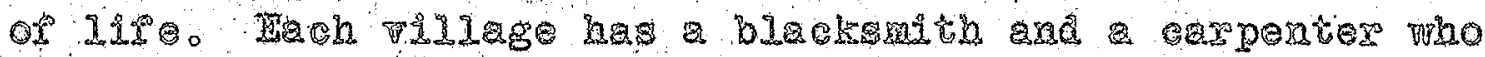

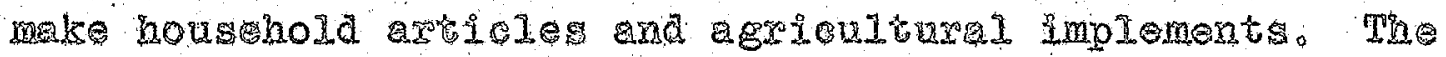

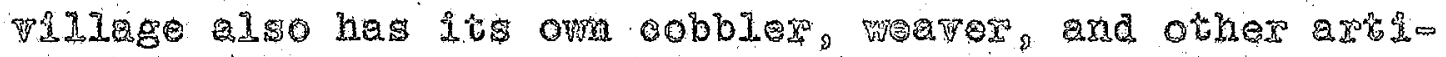

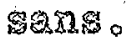

Mgrdetiturad practices in the East are goneraid old

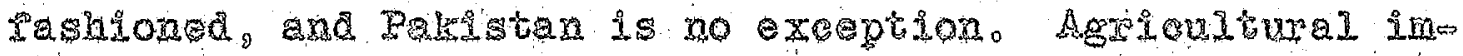

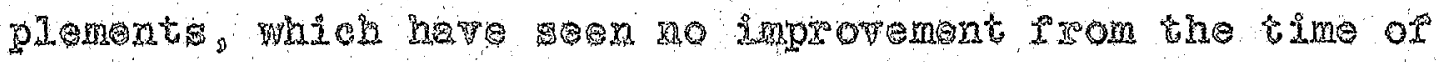

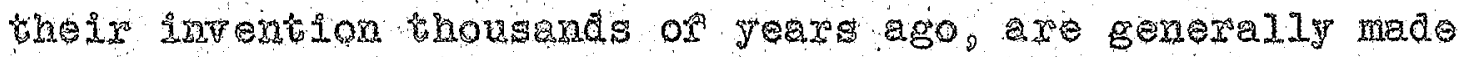

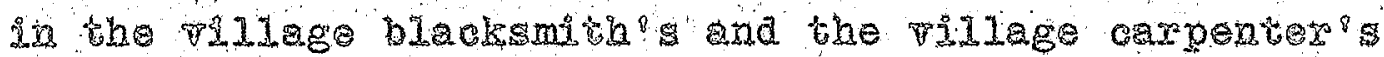

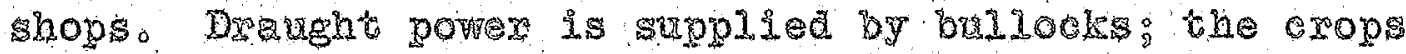
are som and bastested atiroly by hod and the grain is threshed catcle These prectices are dictated by the econons Iinitations of the cultinator and the astar of Iasgenged industry in the cowntry.

\section{Iand Utistion}

In an agricuIturat coonom ox Pakista oultraton or Iand torm the nor octupation or the pople and 85 per centh or tho populaton is dependon on it. Thererore an examine

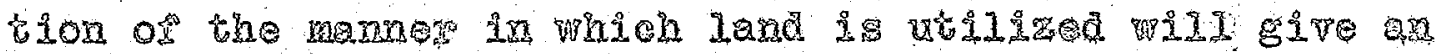


Ided or the conong of the comatry and tho sope por puture derelopment. The lassirication of aras In a inerent propinees is given in the pollaning cable.

\section{WABTE III}

CHASSTRTCATION ON LAMD

(Ia ming a aros)

\begin{tabular}{|c|c|c|c|c|c|c|}
\hline $\begin{array}{l}\text { Hotiace } \\
\text { or state }\end{array}$ & Horest & 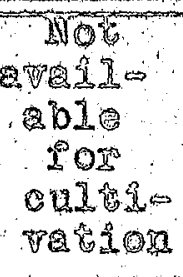 & 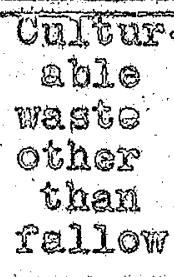 & $\begin{array}{l}\text { Cusco } \\
\text { pernt } \\
\text { SLILo }\end{array}$ & $\begin{array}{l}\text { Met } \\
\text { aped } \\
\text { sowat }\end{array}$ & $\begin{array}{l}\text { Total } \\
\text { area }\end{array}$ \\
\hline 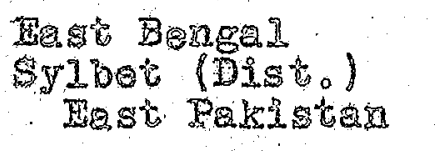 & $\begin{array}{l}300 \\
\frac{0.2}{302}\end{array}$ & $\begin{array}{l}5.7 \\
0.3 \\
6.0\end{array}$ & $\begin{array}{l}3.0 \\
\frac{0.7}{307}\end{array}$ & $\frac{2_{0} \frac{h_{0}}{0.2}}{\frac{0.06}{200}}$ & $\begin{array}{r}25.7 \\
107 \\
17.4\end{array}$ & $\begin{array}{r}29.8 \\
3.1 \\
32.9\end{array}$ \\
\hline 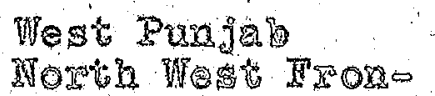 & 102 & 6.8 & 10.5 & 201 & 26.6 & 37.2 \\
\hline 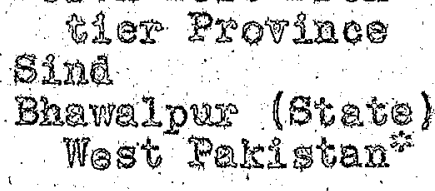 & $\frac{0.4}{0.9}$ & $\begin{array}{r}2.7 \\
304 \\
0.9 \\
230\end{array}$ & $\begin{array}{l}2.9 \\
5.2 \\
103 \\
59.9\end{array}$ & $\begin{array}{l}0.6 \\
5.2 \\
0.3 \\
0.2\end{array}$ & $\begin{array}{l}2.1 \\
3.6 \\
2.0 \\
26.3\end{array}$ & $\begin{array}{l}8.7 \\
30.7 \\
\frac{10.5}{80.5}\end{array}$ \\
\hline Tota 1 Pakista & 5.5 & 29.8 & 23.6 & 20.8 & 43.7 & 123.6 \\
\hline
\end{tabular}

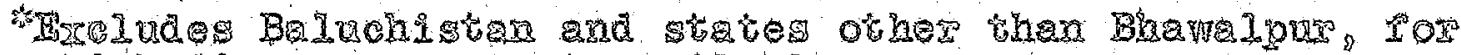

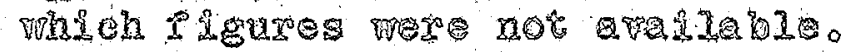

1. Pakistan (London: Thomas do la Rus and Co. 1949)

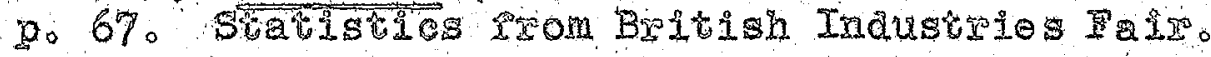


As wil bo seon trom the pregedieg table, the area wader forests is pery small. The we wheh is not availo 2ble for oultipation is considrable (29.8 million aces).

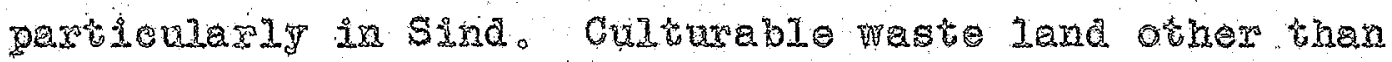

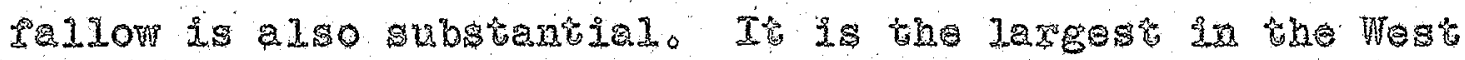

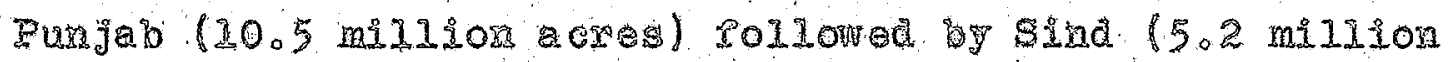
acxey and vory smal in Hatern Fekistan 13.7 . million acreslo How

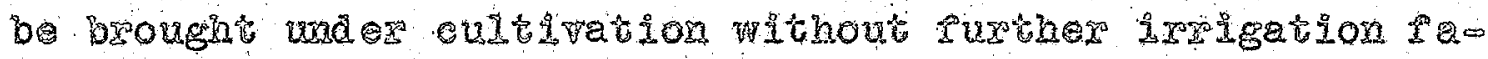
aslities.

\section{Ipesegeton}

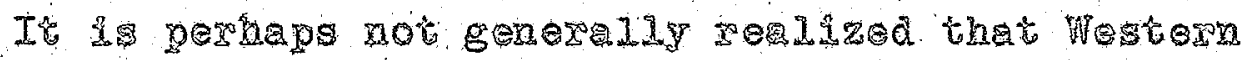
Pakistam is the most intensively ireigate area in the porldo Whathin the last 70 years, deserts here been turned into

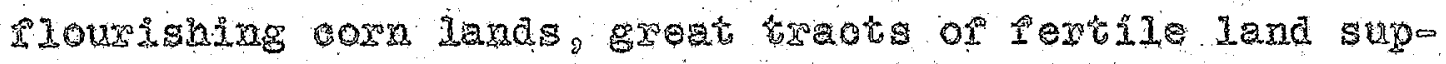
port milions of cultivators where formeriy only nomas madered. Hesses of riood watex hase been chocked by headoworts and dams and guided into channels to pertilize the surrownding countryo.

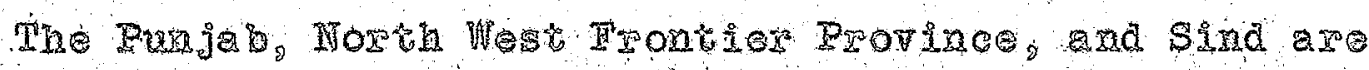

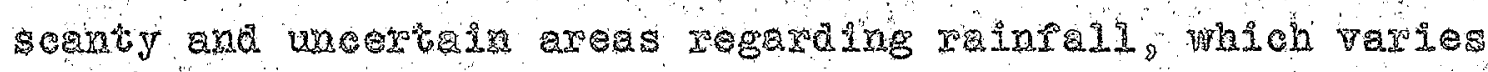

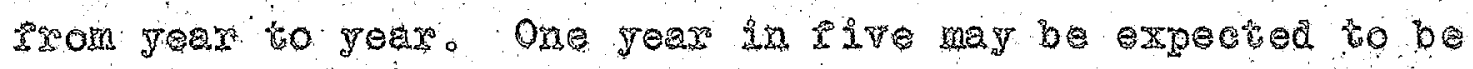
a dxy year, and one in ton gear of serere drought, In ang case, it is necessary to get water sor the dry pesiod or ach sear only those who can wisulize the prect of a droughtw de desolation of the sield, the peopto worn and 


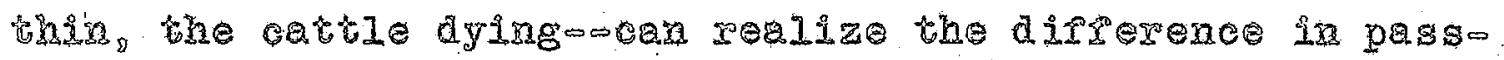
ing to as irsigated area whore the crops are grean and gromin is plantisto

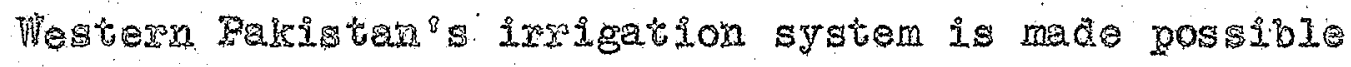

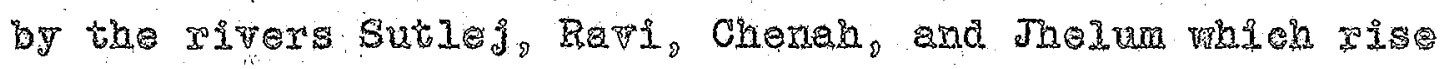
in the Hawalay and row southwas, quartering the great West Pugab plain until they join the mighty Indus in its 2,000mine journey to the sea A network of eands has

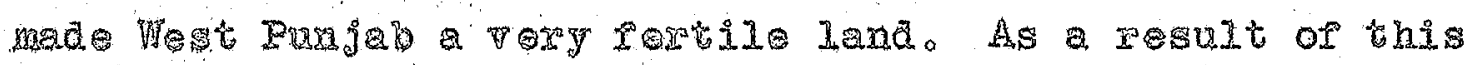

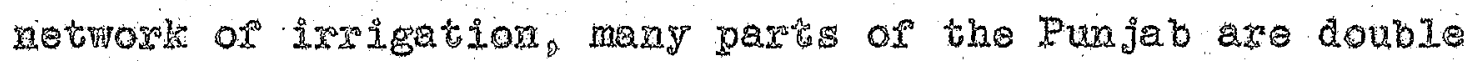
cropped. The nost important of these canals are the Uppare Jhalum canal, the Lower Jhelum anal, the Upper Chenah canal, the tower cheneh canal, and parts of the Joper Bax Doab cand and the Lower Baxt Doab canal.

Sind with its poor rainfall is oven more dependent on Iroigation than the Punjeb。 The Sulkur Barsage; or the Lioya Bargage as it is also known, completed in 1932, is one of the laxest moxks tor irrigation. It has belped to bring $6,000,000$ aexes under cultitation. This great baro trage consists of 66 spans, ach 60 peet wide, the opening being regulated by steel gates ereh weighing 50 tons. The barrage is about a mile longo the hotal length of chanels ard water courges connected with it is 36,000 miles.

Serangy per cont of the crop aree of the West Punjab and 77 per cont of the arop area of Sind are irpigated in contrat to ondy 8 per cent of the axop axed of Eastorn 
2

Pakistan, The necessity for itrigation is not great in Tastern Pakistan where rainfall is plentiful。 This is why the irgigated area there is rather small.

There is still immense scope por the extension of the eanal system, and raxious projects aro in hand to ixrigate more land. The Lowex Sind Baryege, to be completed in 2953054. is expected to irrigetre about two milinon aeres: and the Thal project in the Hest Pujab, 83i,000 20res. The Milanwli and Rasul hydromale expected to bring waser irrigation 440,000 and 750,000 aexes, respectiveiy. In addition there is the Warsak hydrowelectie groject in the Horth Hest Frontier Protinee which is expected to make that province selposurpieient in rood. Serreral other minor irrigation projects in Baluchistan. East Bengal, and Bhawalpur are also in hand. with the execution of projected irrigation schemes in the West Pujab and the completion of the Lower sind Barrage, it is expected thet agricultural production in this region will increase by about 10 per eent of the normalo

A new ere has also begw in regard to tubewelis. In certain ways well ixtigation is raore satispactory as the

2. Rxchard Symonds, Making of Pakistan (London: Febere \& Faber, 1949), po 107.

2. The Second Year (Karachi: The Government of Rakistev, 1949, po $297 \%$ 
weter, being alficult to obtain, is used with eare; canal water is orten used too larishly and causes mater loging. The goresaren is now introducing: small water pumps in cero tain areas or Punje.

\section{Crot Production}

Rice and wheat are the main Lood erops or Pakistan. and aout threesifth or the total cultrated area is whem those erops. Rice is chierly grown in tast Pakistan and is the staple food of the people or that region. on the othex hand, wheat is largely grown in West Pakistan and forms the staple food of these parts. Jute and cotton are the main eask crops, and are malnd grom in East and West Rakigtan, zespectroly. They occupy about 9 per cent of the total cultivated area. Pakistan produces about 75 pex cent of the total production or jute in the morid. cotton is mostly or long staple varaties and, like jute, is mino Iy exported to other countries. Both these commodities are renarkable tor their superior quajity.

The area and yield of principal crops of Pakistan are given in TabIe IV。

Food Cgops: Food crops play a very iraportant rolo in the econony of Pakistan. They account for about 85 per crit of the total area under pxineipal crops. Food necosm sities of all kind axe bundant enough to support hers population with a Ifttle supplus to export. Method ox 


\section{TABIT IV}

$$
\begin{aligned}
& \text { PRINCTPAC CROPS OH PAKISTAN } \\
& \text { (000 onittitod) }
\end{aligned}
$$

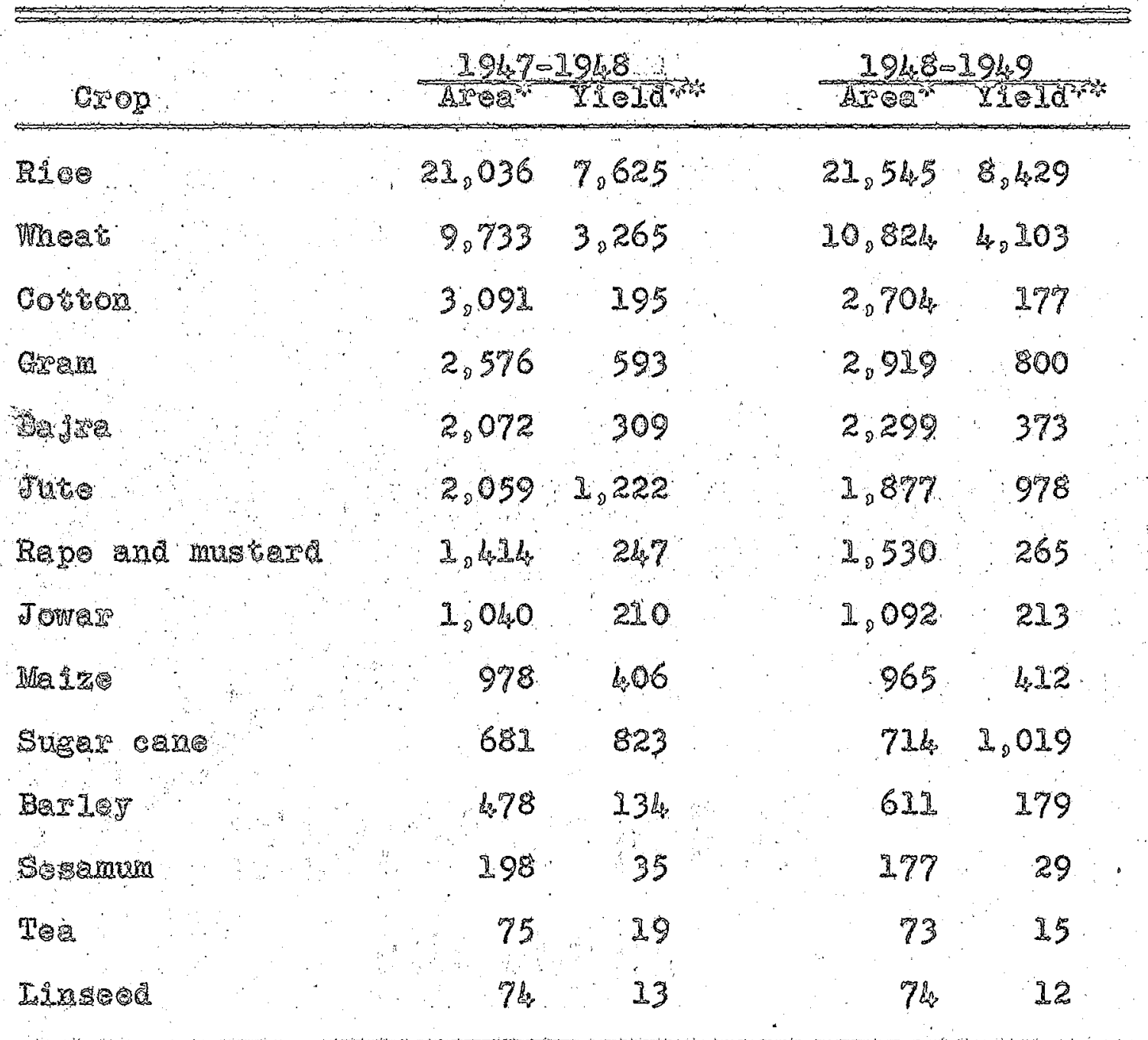

\footnotetext{
\%In 205

镂I $\operatorname{tans}$
}

1. Beste Faets abouk Pasistan IKarah: Coreranent or Rakistan 1950), ppo 12 -160 


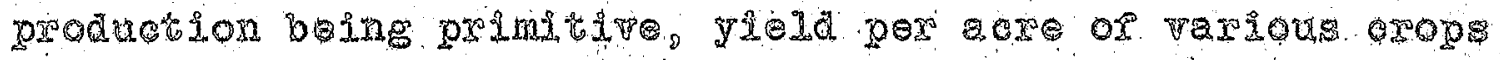
Is low a compared with othex couratries of the world.

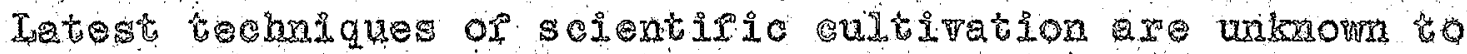
the cultivatow, and he has no mean to bus the modern mo chinery. He is not wen awe of the application or sio encitic tertilizexs.

Rier.mige is the principal food crop or Pakistan. and its production is concentrated in Fatrom Pakistan where it is the staplo rood or the people. That area is not

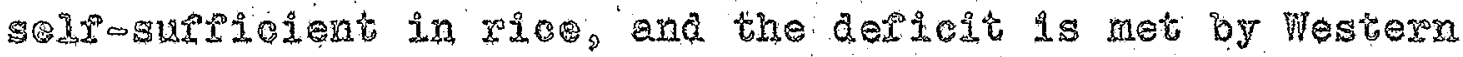
Pakistan。

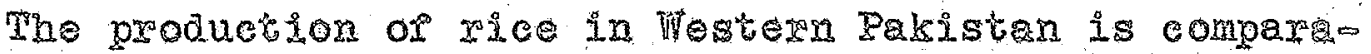
trvely werg much smallex than in Eastern Pakistan, tet jo has a suplus This is so becalse wheat is the staple pood or the people or this area, which is arailable in abudance So that a substantial part or the producton or toe is not

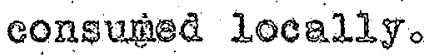

Wheatom wheat is the most important sood erop next to

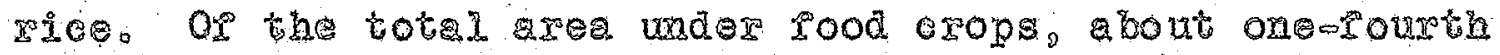
1 wader wheat. The production of wheat is concentrated in Western Pakistan where it is the staple sood of the people. The pxoduction is more than suploiont for local gequiro mont, and surplus is avaldable ror axport.

Other Food Cyops on Anong the codser rood grains, grem, bajra, jower, mo la and barley are the important crops. The produetion ot these oxops is conined mostly to 


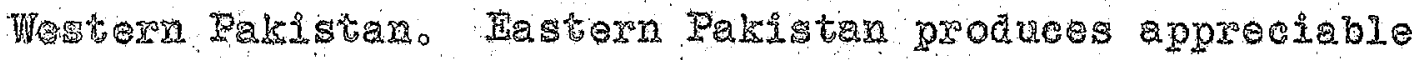
quertities or suga dano

Hox-100d Cxops: Who non-rood crops are mainly grown

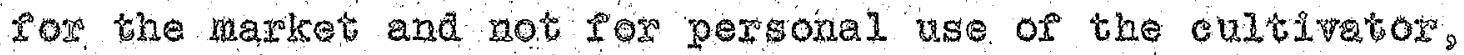
and as such they are an important ractar determining the rolume of purebesing powex in his hand. The area und er these erops is tery smell, being only 9 per nent of the total cultirated axea Jute and cotton are the main cash copos.

Jate.cotuce is the rost lmportant non-tood exop of Eastern Pakistan and is the golden ribre os the countyo

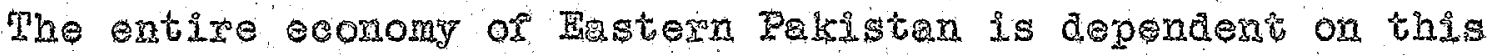
asop. At prosent it comands oxcellent price, and the prosperity of that paxt depends on suis oxop.

Pakistan and India together hold a Tintual monopoly of the jut producton ar the mold. Pakistar produces a bout

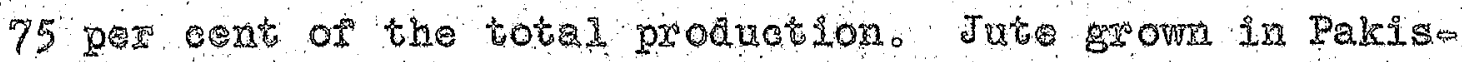
tan is rengakib for lts superdor quality。

Exegp In the cowntes of its oxigin, rexy littie is known about this trable pibe This is pexhaps due to tho pact that its conmerial history goes back littlo more than a cercur: also perhags berase its products are laxgely utilitarian although extremely impoxtant to modera commese.

Jute is extratod rom plants ot the gexus Coxchosus. The plant is an annual, gow 20 in a sing 20 stem without

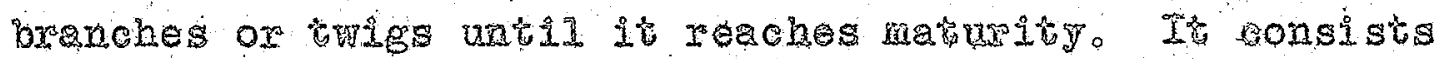


of a woody stok suryounded by bost layex in which the ribre is developed: it grows to an arexage helght or eight

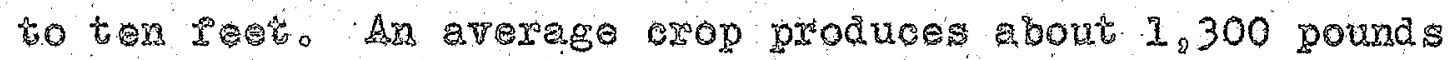

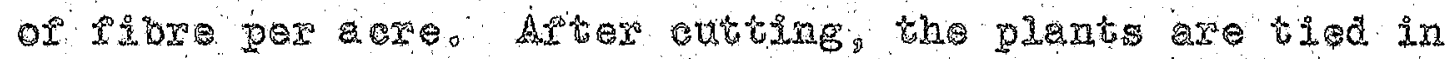
buadles and lett por about thee or poug days to allow the leare to drop of 5 . The brodles are then sumerged in water por a bout 10020 days. This process, called retting, results in the sermentation or the sot pith or the plant. which aissolves and leaves the fibre which can then be easily separated rom the stick. The ribre is then washed. dxied; ano made into bundles ready por sale.

The mployment of jute fabrics as saking ox pacing material mas lenandx in the history of the ifibe and an orent of greatest commercial importaneo. Mifing jute yarn with cotron and wool led to the manuetare or curbains, upholstery, carpers, and dress meterials.

While Rakistan has a ritural monopoly of jure produce tion, Trada has anost all the jut mills. Pakitar thereo Tore mat aport 211 her juto in rew rormo Fecilitios soto the esy and speady morament of jute axe not yet atailable

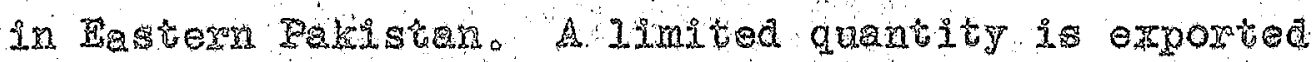
through her post of chitragong but the bulk of the expox Q De surplus mist pass through caleutr sa the Dominion of India berore reching roreign destnations.

CotronomCotton is tho principal cash orop of Western Pakistan. The anual production is about one and hals million bales of 400 pounds aro About tromothis or the 
Gotion ptoduced is of high grade, Iong staple American Farieties. Thexe are vexy few cotton textile milis in Pakista. Arrangements por the ginning and pressing of cotbon into balos, howerer, are adequate, So most of the cotton has to bo axported.

the cotton grom in Pakistan ma bo blassiried into

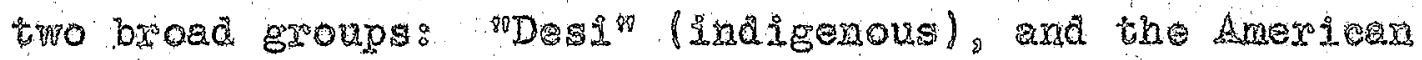
Tariotios. The American varjeties occupy the bulk of the

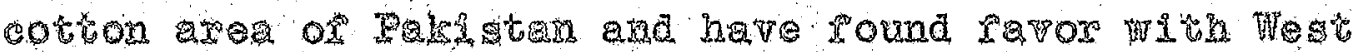

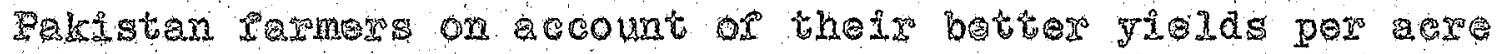

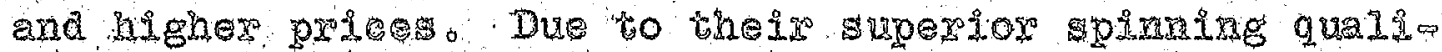

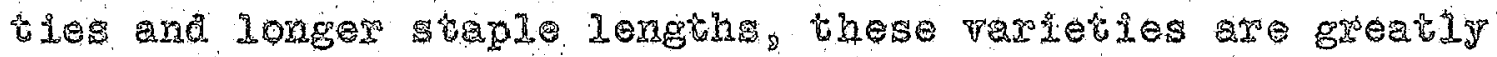
in demend in the toming induscres of the worid por mand Raturing eloth or siner counts.

Qther Hoq-Pood Grops.wThese are oilseeds frape, mus-

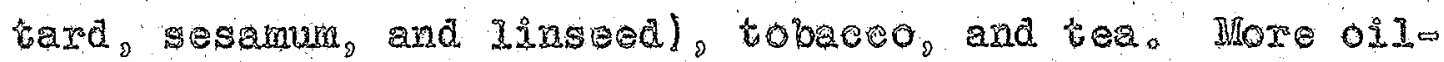
seods are produced in Wostern then in Eabera Pakistan。 The latters, howerex, produces the greater part or tobreco and the entire quantity of tea Pakigtara besc tea eus tomer is the United Kingam. To encourage the consungtion of Baistara teas and improve their quality, the gorernment has tormed Pakitan Tea Boaxd. Researoh is vital for thls indugtigy and the Board is respongible ror supertising the resareno the production of tobacco is negligible and

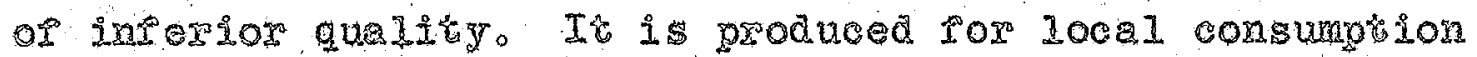
ondy? 


\section{CHAPTER IV}

\section{DEVELOPMITIT PLANS}

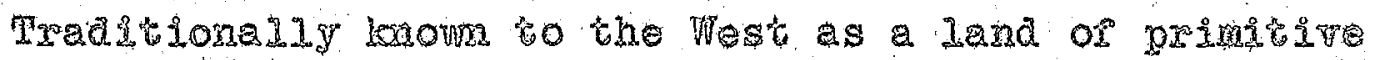
people having litule nowledge beyond the woodon plough and

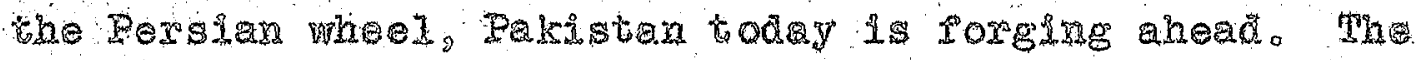
goveramert id of the tirm belier thas no cowntry in tho modera world car progress and take its rightrul place in the comity of nation uniess and untl it has dereloped industry and a balanced eonomy. Horeotern, the impression In government idros prevalis that it is not only wasterul. bet it takes too long to allow the industrial potontigities or a country to be dereloped in a haphadard manner by pris pate entexprise. Tho govenntent mast take important part ir planning, encouraging, and derelopidg industry and in helping those who are desirous of taking an active share in the derelopment of their eourity.

The governant of Pakstan thererore decided that a high place must be assigned to shemes of nationebuilaing signiriteance; and in oxder that such sehemes may be properly coordinated and their priorities neg bo assessed. in the Iight of national importane, it set ap a Derelopo hane Board whose protions are: 
a. To pordinate depelopment plans, central and proc

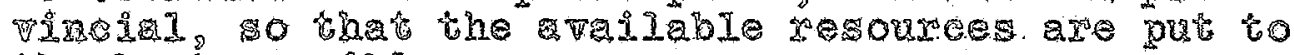
the best possible use.

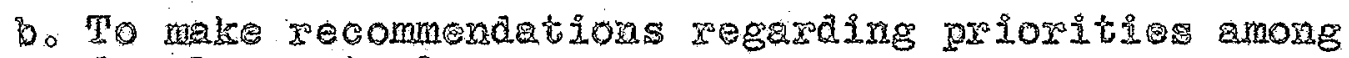
derelopmenc plans.

C. To prepare memoranda on mattars of general polioy arsecting development as a whole os any special aspect of ito

d: To ac as a dearing house or ideas and iaromation relating to development, and to bring to the notice of the Mismistries ideas or schemos which mat aid derelopment.

- To keep a wath on the progress or derelopment sobexes in oxder to remove bottinecks and dirio

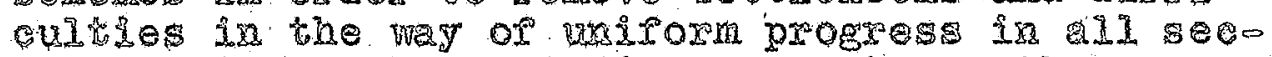
tors, and to make periodical repores on the progzos of defolopment schemes to the cabinet.

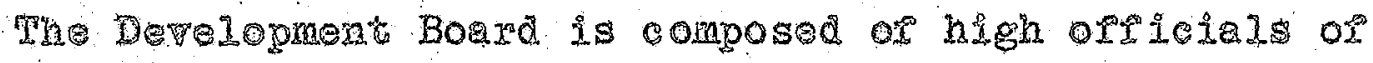

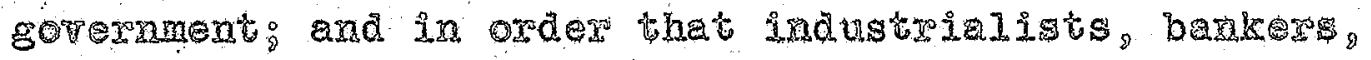
Gusiness men, mexchent; and other interests may a Iso be associated wh the goremment in an adrisory capacity in the important task of planaing and development, the govern. ment also set vp a Planing AQvisory Board consisting of ofsicia is nonoricials. The Punctions of this Plano ming Adrisory Board are as solums:

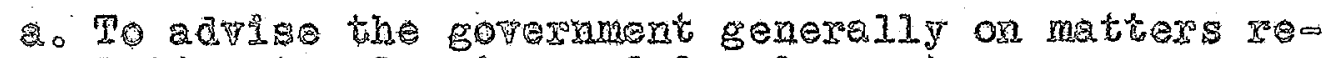
lating to planaing and devolopment.

b. To roview the progress made in implementing the planso

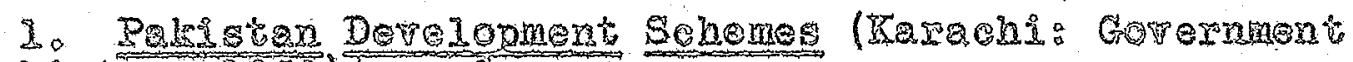

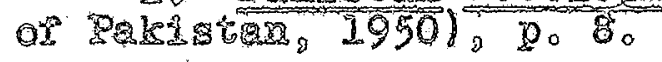


- To educate the publie in regard to the recessicy ror Various derelopment schemes undettaken in order to get theix enthusiastic eoperation. ${ }^{2}$

\section{Tyes of Seheres: Histotical Background}

Shorty berore the end or World War II the late gorio emanent of India, sealizing that it would soor be saed with

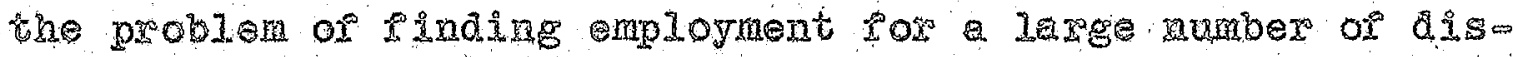

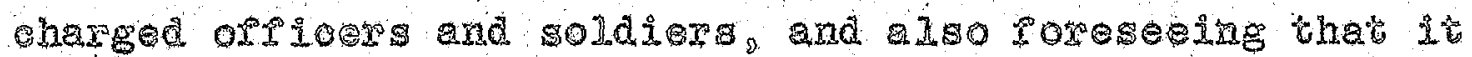

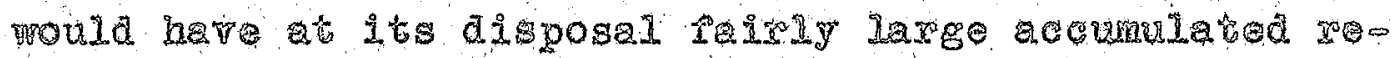
Sores, set up a Deparment of Planning and Depelopment

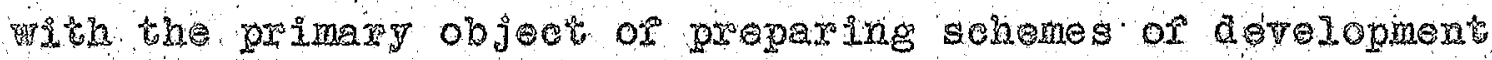

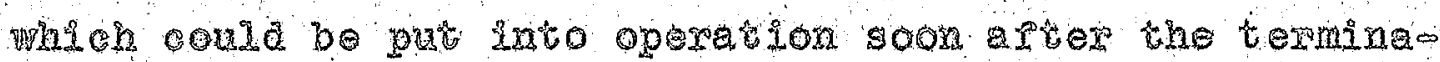
tron of war. Whis Department, on the one hand, set un a namber or panels with a tew to surtergng the requirements o the country tor various industial products the existo Ing production, and the potentralities rox exparson: and, or the ouher hand is asked the protineial govemmeats to ptopare sehemes of development which conld bo undertaken with the help or either loans ox outright grants rrom the centrel goverameat to the provineial governments.

In response to this inrifaton the promineIal gorerno ments of waitided Iraia prepared a large number or schemes rox derolonment. The paxels set op by the late goverament

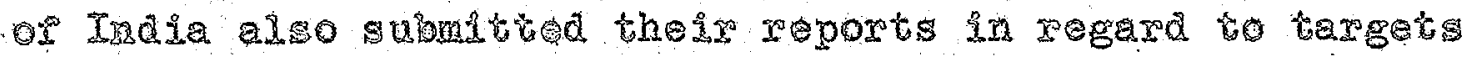

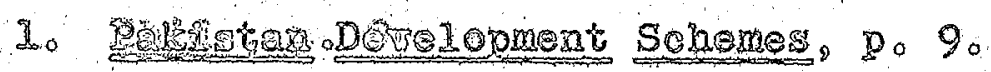


or derelopment or industries orer a rany wide rield. How erex, beiore action conld be taken on ans substantal scelo or the reomendations of these pariels or prograss could be made trat string the porinolal schemes, partition or the covatsy took placis.

The Derelopment Board set up by the goremment of Paso

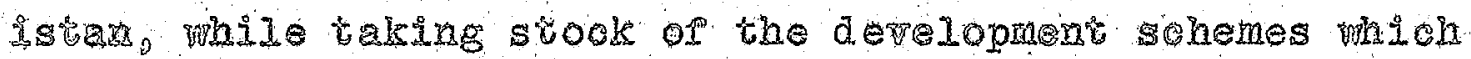
bad bece prepared in the past by the provitrees, appresated that thes schemes. mo far as they related to the torgin toties which now constitute Pakistan, sequired constareble modicicaion it vien of the sact that the two important provinos of Parigan, mamely, Pud and Bengal, had also

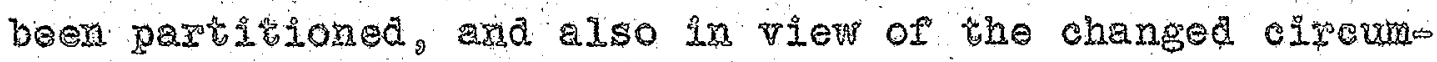
stanee whin demaded that groater emphas should bo laid upon ectain essentad and producive shemes such as the

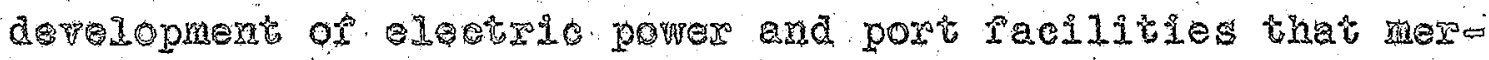
Itod immediate atsontion.

According gy; the Dereloptent Board asked the provino

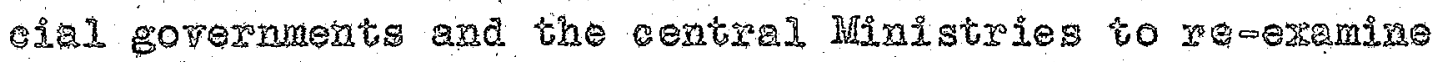

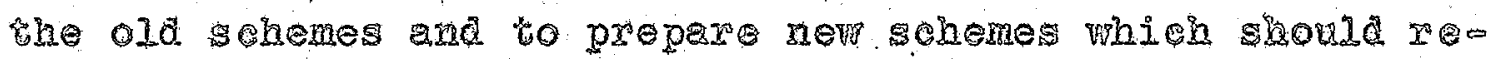
lato primasy ty to the pollowing subjects:

a. Production of hydromelectriesty and other foxms of power.

b. If intenance and exprasion of compriog ions, ino luding ports.

G. Eloloitation or mineral westho

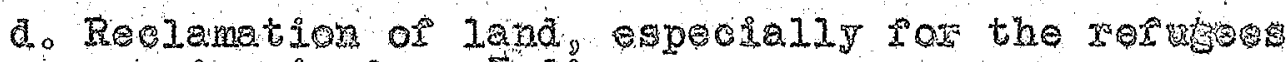
pousiag in r rox India 


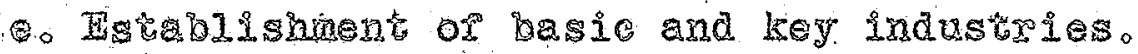

T. Tralning of temnical personnel required ros indus tond development.

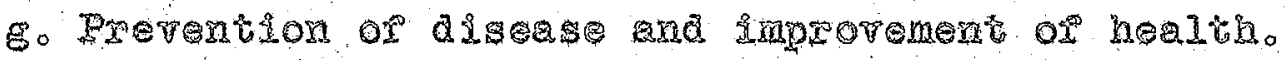

h. Largesene development of risherias and tho Ish ind $2505 \%$

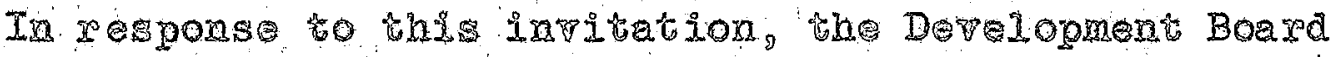
recoived a lage number of schemes and it has considered 202 schemes subrithed by the provinolal coveraments and by the Ifnistries or the central goveramext: so par it bas apo proved 105 sohems. The estimeted cost of the plane which hare been aprored by the Derelopment board spread ores period of fire Jears movid anownt to 1,120 mijilon pupees $(1332$ milionlo this anowat does not inelude expona tures on those senemes wich, in the case or provinces, the prowineinl governments can met out of the is own rem soures and when, in the case of the central govemnent. are regarded as part or the departmental mormal a chitity. In order to thance the derelopment plaxs which come botore the Board, the pollowing wrangement ha ben made. In those eases where the sobemes are subltwed by the pro

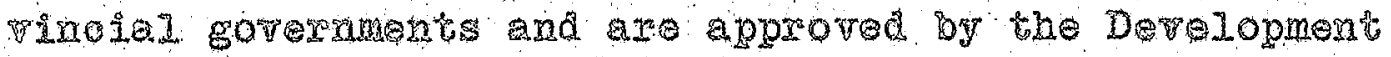
Board, the contral gorernment adrances loms to the

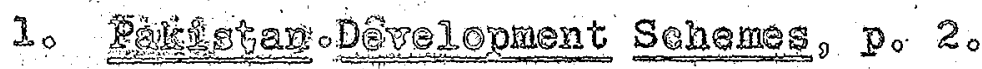

2. $\log 0$ dito

3. $\operatorname{toc}$. 
propineinl governents sor Pinaneing these schemes, and the provintial goverments are made responsible pos carrying them out. In those cases where the sehemes are submitted by the innistries of the central government and are apo. proved by the Development Board, Pinaneing is done out or the central exchequex and the project is xwe by one of the Ministries of the central goverament.

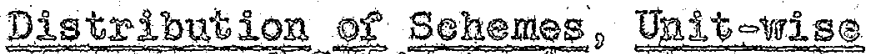
and Subjectomis:

It has been mentioned that so Par the Development Board has approved 205 soheres, or vphoh the total estio

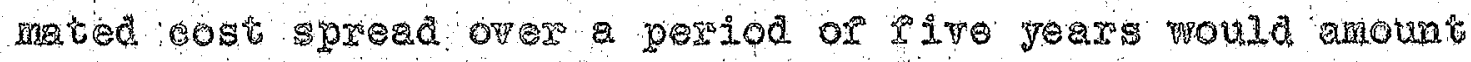
to 1,220 millon rupes or 332 mi13on. These schenes coverg a wide rield of subjects such a lropgation, agra Qufture, industry, generation of powe, bealth, commications, and go porth. The rollowing two tables show the dis. trobution of this expenditure provincewpise and subjecto wise, in which the anourts that are expected to be spent on development sohemes are shown.

The proposed experditure on industrial development is pelatively small since it is intended that the cerelopment of industry in Pakistan should be lasgaly through private enterprise; and por this reason statio expenditure is meant

1. Pakistan Deralopment Schemes, ppo 4050 
PABI然

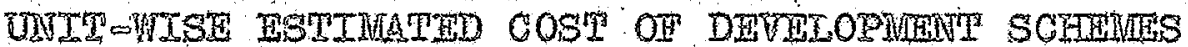
APPROVED BY DETHEOPIUENT BOARD UP TO $2-28-7950$ (I D 000 wevpes)

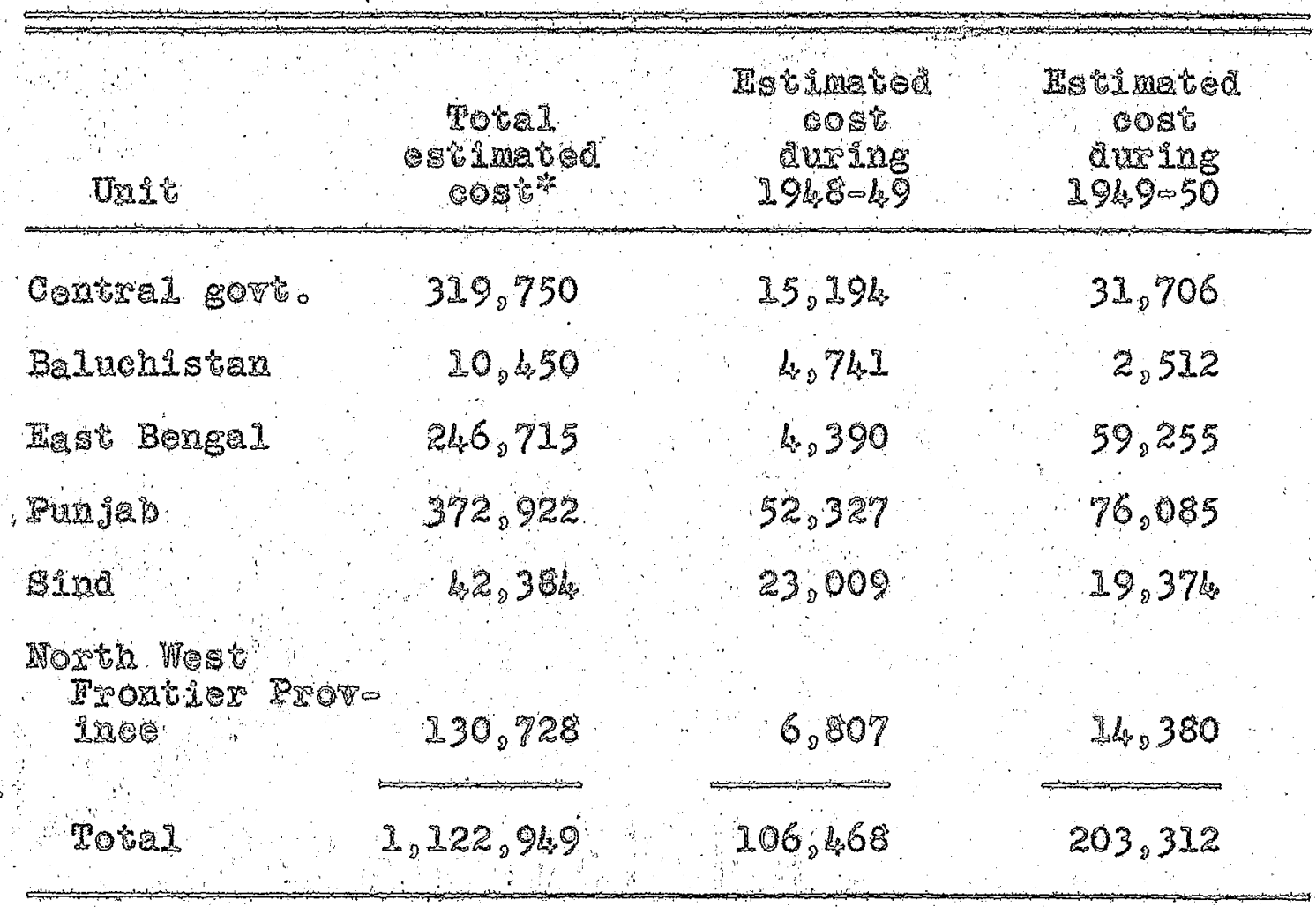

解100:332.1/2 5pees 
PABLE VI

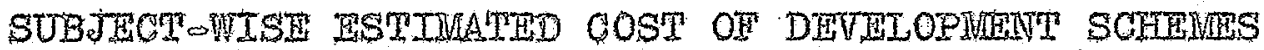
AFPROTED BY DEVTLOPUENT BOARD UP TO $2-28 \circ 1950$ (In 000 rupas )

\begin{tabular}{|c|c|c|c|}
\hline Subjogc & $\begin{array}{l}\text { Total } \\
\text { ostringed } \\
\text { cost }\end{array}$ & 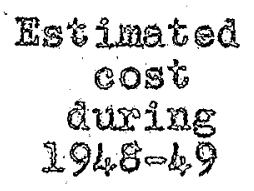 & 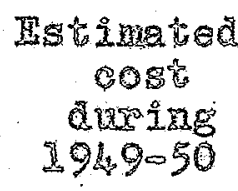 \\
\hline Agxieulture & 160,466 & 2,043 & 36,913 \\
\hline $\begin{array}{c}\text { Brodadest } 208 \text { nd } \\
\text { pQ12016y }\end{array}$ & 5,000 & 3.200 & 1,800 \\
\hline Compua carions & 331,200 & 36,746 & 72.930 \\
\hline 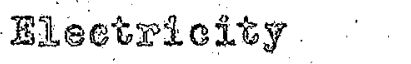 & 295,300 & 38,883 & $3 x, 400$ \\
\hline Hea IE: & 30,42 & $6,36 k$ & 21,408 \\
\hline Ind vistigy & 75,010 & 24,915 & 8,295 \\
\hline Irongen Ion & 222,689 & 3,94 & 60,328 \\
\hline Vatsixas & 2.773 & 373 & 2,378 \\
\hline Commereo & $\begin{array}{l}1,060 \\
\end{array}$ & $\Leftrightarrow$ & 160 \\
\hline Total & $1,122,94,9$ & $106,4,68$ & 203,312 \\
\hline
\end{tabular}




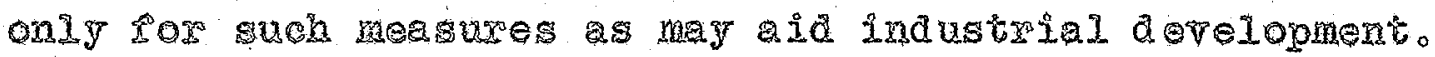

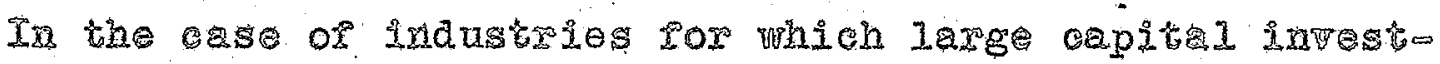
thent is zequired the gorermert, pindiag little response

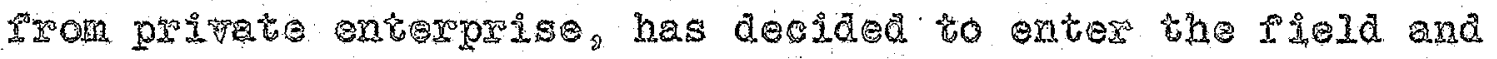
has reenty passo the Industrial Dorolopment det. Under this Ac the goverament is estabishing copporation tea

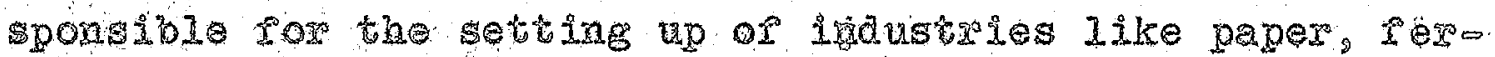

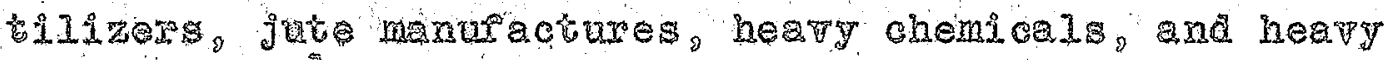
1 angitaecing

\section{Bopievitural Develoonent}

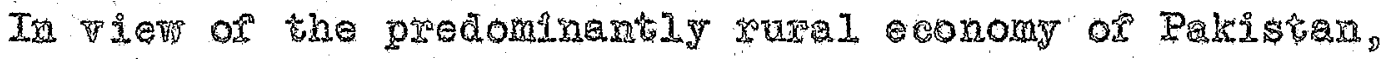
Initial emphas is mot pertoree reat upos the reconstruetion and deveiopment or agrienlere and or industries based upon or connected with it. Traphas in the pirst place has bea Iaid on schemes which tend to increase the production of sood: to increse the ofriejengy of the methods of agrio Gultural producton, maxketing, and aistrlbution: to stime late the production or raw merials or lndustries both rox

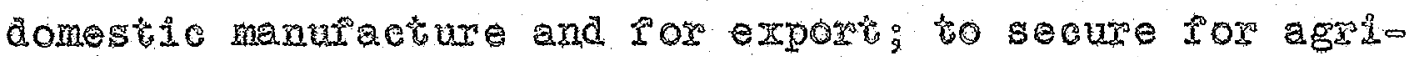
cultural produe an assured market at a price remunorative to the produed and rair to the consumer: and to secure contineus and protitale employent in agxigulture by the

I. Three Years of Eakistax (Karani: Fakistan Pabldortions, T95I, D. 540 
ixtroduction of Incensive scientivie methods and the bring

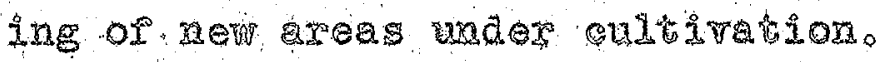

Irrigation Projects: Though Pakistan alzeady posteso

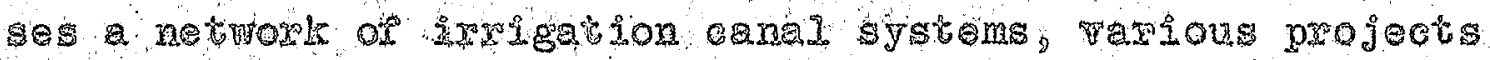

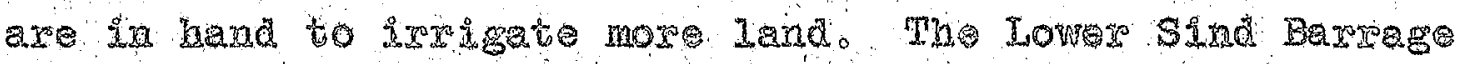

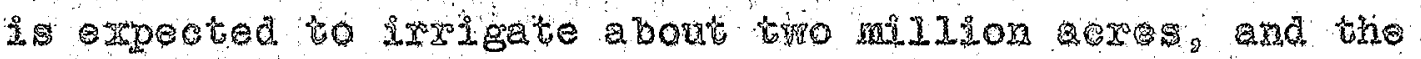

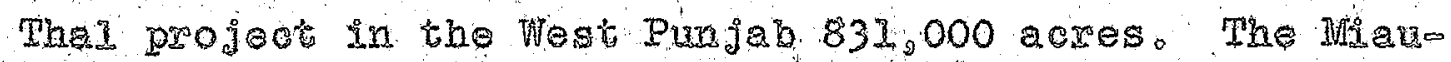

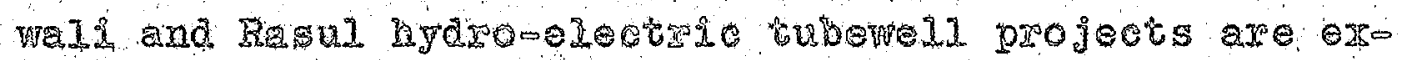
perted to bring under irrigation 140,000 and 750,000 aczes. respectrely. Iro adition there is the Warsw hydromelem tric probect in the Horth West Frontiar Province which is expected to make thet provine selposuritoisst in sood, in which it is at prosent aideract area

\section{Suminary axd Crinulative Esfect os Sohemes}

It rag be interesting to have a brief sumary of the dorelopment schemes and their cuniative erpect on the econorig of Pakistin. It has betastimted that if schemes rot the generation or alectric power which have been ap. proved are completed, the production of electrie powes in Fakistan will bo increased by $160,0000200,000$ kilawatc。 This powe wisl be used por sunning rew and latgeoseale

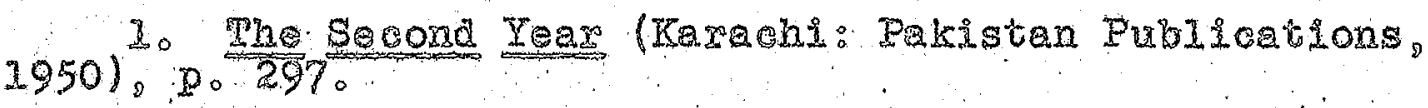


Sactoxies whieb axe being ostablished all orer Pakistan. expocialiy por those industries wich use pakistan rav ma terials such as jute, ootton, hides, skins, and the like。 It will also be used for the establishment of cottage lino austries by proriding cheap electrie power to the county side. It will also be used in working puths for reviaiming Ind which has been lost to cultivation or aceurst of thatero logging and if there is suxplus power, it may also be used rox the oledtriftedion of trains on certain specified secm tots。

It has diso been estimated that if all the frroigation and agrieutural schemes approwed by the Board axe laplew mented, these mill have the erpect of providing irspigation sallites in an area of 3.7 millon ares. The increased Irrigation railities in this area will yield an additional 1.5 milifon tous of erops per anum. These rigures do not Include the aditonal area in whoh irroigation facilities will be prorided by the Lower sind Barrage, which is estio mated to bo 2.8 mill 20 acres.

Although the full road development program of Pakitan has not yet been prepexed it is estimted that as a rosult of the schenes which have alyeady beon approved by the Board 3.500 additlond miles of zoad will bo constructed in the coutse of the rext rive years.

A number os hospitals and dispensaries will bo estabo lished, and sererel instituteg for research ir medical and Foterinary science wll also be set up ix the cotrse of the 


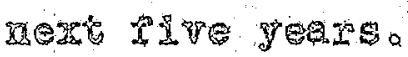

Special atcation will be paid to the derelopment of the port or chitcagong. As a result or this expanson the capacisy of the port ror handing shigs twhich was of the order or 0.5 mildion tons per anxum at the time of partio tion) will be increased to over three milion tors pex annum.

Daring the last World Wat the transport system of Pakistan was subjected to tranendous strein by the noweo ment or troops and supplies: and, on the other hand, the

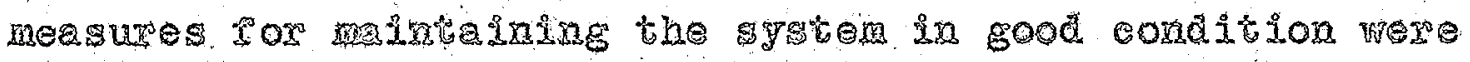
sot taken. It Is now proposed to pay special atchion to

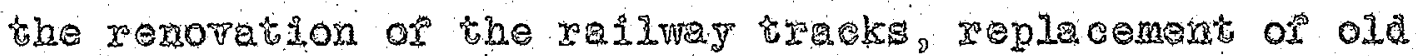

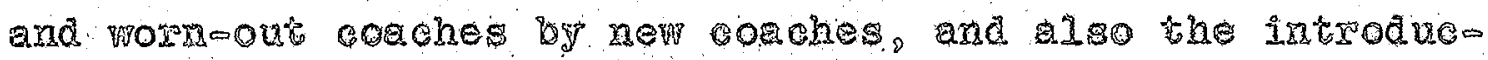
tion of Dresel electric exgines instead of the conloburning eagines.

\section{ReLaton of Stato to Industrit}

The gorerament of Pakistan believes in planed economy 2s distinguished rom abionalized indusuries. Ir order to exsure the industrol development of Palsisara on sound Iires, it is necessay that suen development should be caso

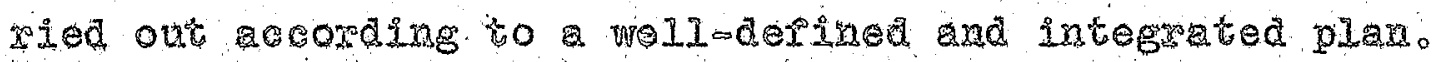
Consideration has to be given rot onl to baladed develop-

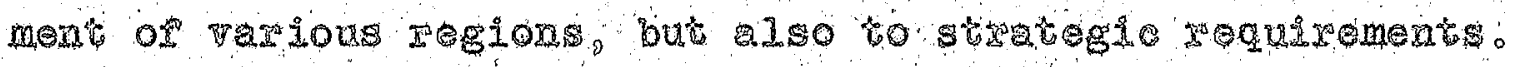

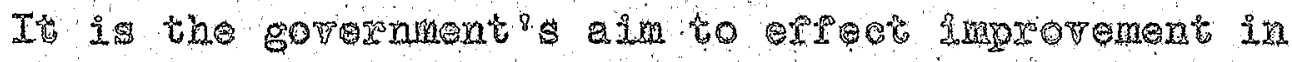

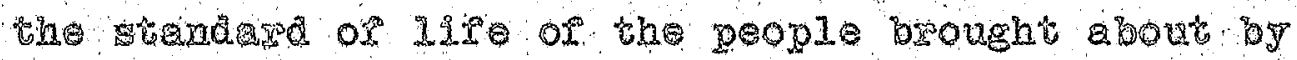


harnessing, to the maxinum extent possible, the corces and treasures or dature in the sertice of the people.

Thare is a generel ageement that monopolies and pub

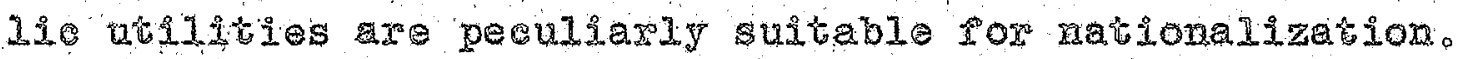

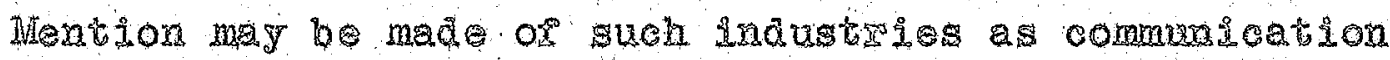
servios like posts, telegragh, telephones, wireless, and

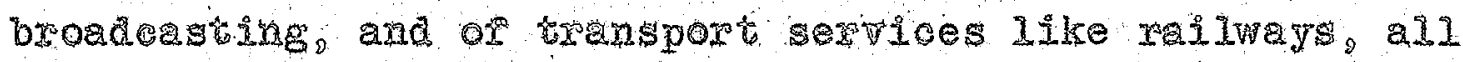
or whoh are already stro omed and sto managed Whb pegard to other industes the Pakistan Gorexment prom poses that for the pxesent, the pollowing showd be owned and operated by the stato:

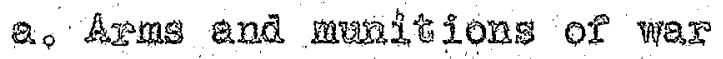

b. Generion of hydromection power

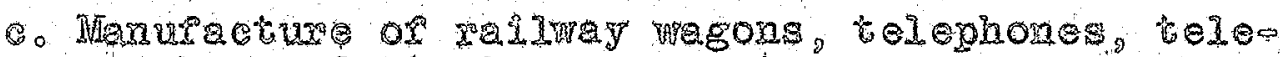
graphs, and yireless aparatus.

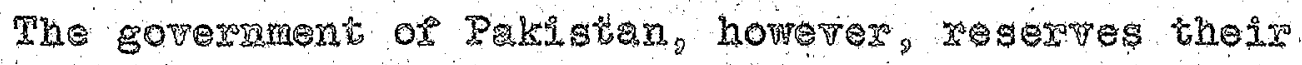

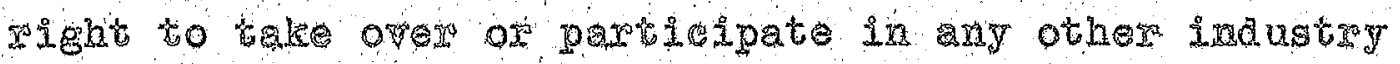
ital to the semolyt or eonomie welloberag of the State. The governent wht ind it necesary in the national ino terest in the event of pritate capital not torthoming ito adeguate meante tor the development or any partoulat la dustry of nathonal importance, to set up a 13 mited mambers or standar wits tore as a means of attracting plyato entergro thar for ang other object.

Assistance co Industi: It is not the tesire of the

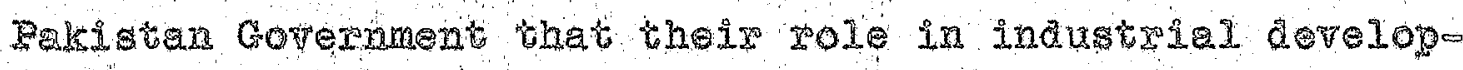

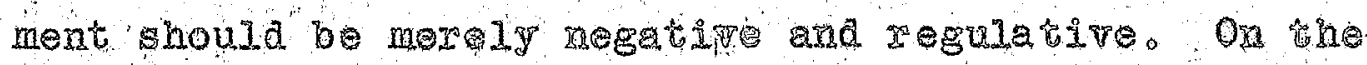


positire side, the goremment will gire all reasonable help tor the establishment and development of private ino austry. Apart Tom the maintenance or peace and intarnal sevelty and the establishment or gtable aministaton. which aro the espential prexequisites of any economio deo. velopment, the gorernment w11 seok to exeate condition In which industry and trade may darelop and posporo

Pakistan"s considerable resources of mineral oil and

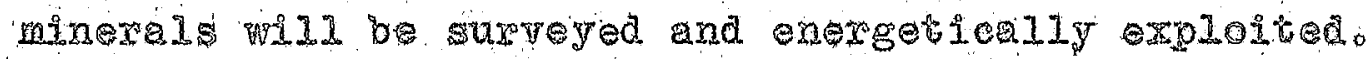
Schanes tox the development of the cownty powex reo sousces be bing worked out, and their implementation mill be accorded the highest priority. Plans rox the smprove ment or ports of Karahi and chitcagong aro in hand and rtegg are boing taken to gear up the transport services to tho maximum erforeney. Measures are also being taken to derelop agxioulture to increase the production of tav ma terrais required by industry. Whe government will continue to rendex all postible as os cepital goods and machinery, por securing essential taw materials rrom roreign countries or the derelopment or

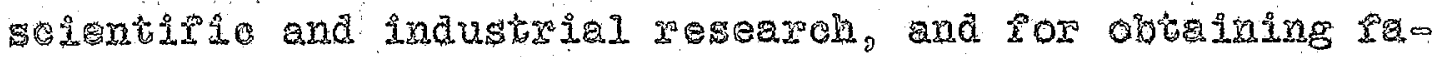
eilities for technical education and training aroad.

Rerinela and state goveraments already do, and rill contrue to, assist industrialists in the purchase of land seduired tor tactoxy ther, and in the provision of

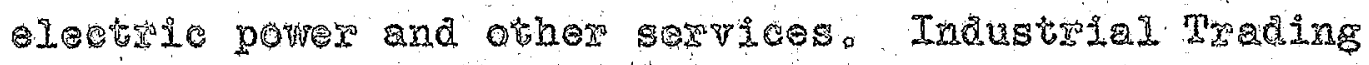
Egtgres dequtely sered with commications, power. and 
mith ractory buiding construeted on the most progressite Iines are being developed ln drepenc surtable parts or the country.

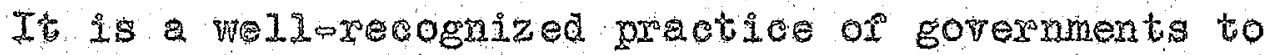
protect new and ascent industios aganst ortside compen tition. The gowernment of Pakistan will a Iways bo prepared 60 give parorable consideration to dams for reasonable measures of protection to industries astabished in Pakism tan. In order to deal with the question of protection to

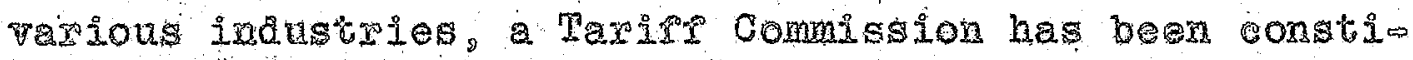
tuted.

Tazton Concsssons: Despite its stringent budgetary position the Pakistan Covernment recognizes that its taxe tror polioy, as fax as possiblo, should mitigate the hazards to whiab new industial projects aro likely to be subject for. Sone "ine to come, and that a reasonable oppoxturity and level of propit should be alowed those mo take part in the industrial development of the country. The gorexn ment has reontin announed the rollowing measutes or wara

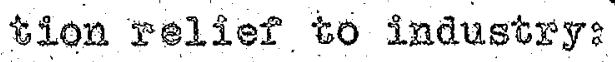
1

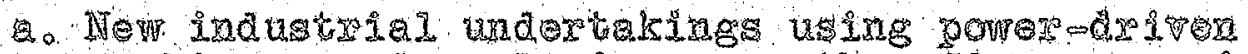
moninery and aploying more than 50 persons in

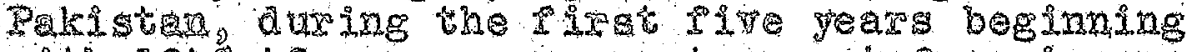

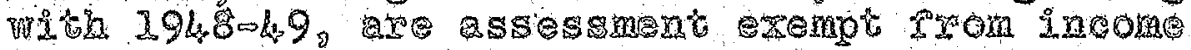

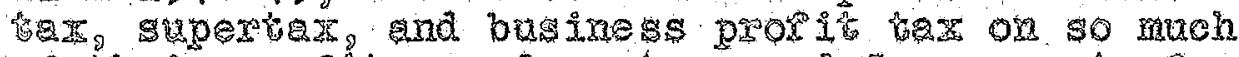
or their proxits as do not exced 5 pere ont or the capital omployed.

to Mfinistry ds Trangties, Bakstan Inauscrs

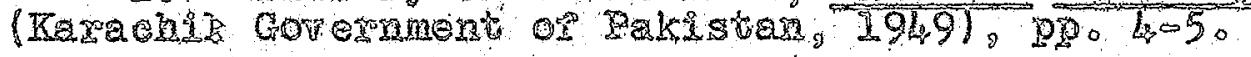


b. A speial dereciatan llowance (which is in ado dition to the normal deprestation al Lowere) is given in the tixst year at the rate of 25 per ceat on boildings erected between Aprid 1,1946 and What 31, 1953 (both d erent on othex buildings.

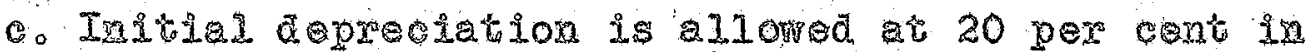
the eas of meininery or plant installed where the mehinexy of plant has not previously been tased in Pakistura

do Depreciatson in respect to plant and mechinery in stalled ox or acter Apxid 3 , 1948 and berore Lpgil 1, 1953 is 110 owed at double the prescribed gerte.

e. An extra depreciaton allowance is given on mo chinery and plant at 50 pex eent or the norma tat

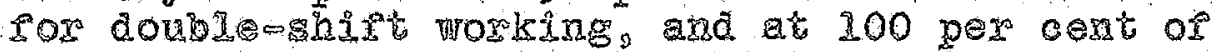
the notmi l ate ror triplesshipt working propore tionete to the number of days auring which double or triple shints re moxked。

1. There provistons in the Ineome Tar Act ror the allonance or expenditure on sejentifie rescarch.

g. There axe arangements tor toliex in wespet to the United Fingdom incone tar. Aprangements por the a toidance or double taxaton between the United states and Rakistan are under contempIation.

\section{Toreiga Captat}

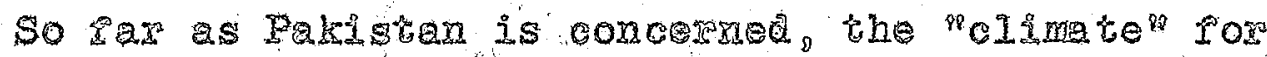
investment mhich investors from abroad so apten go in

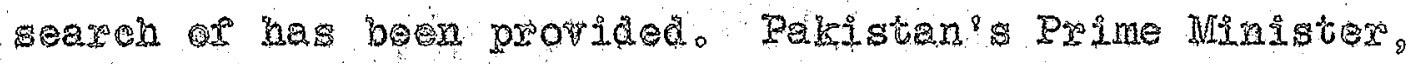

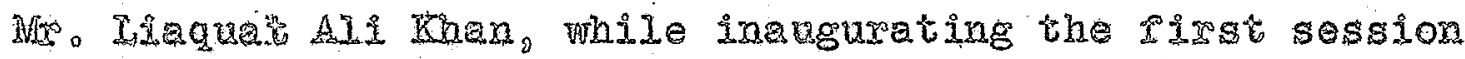
or Rakistan's Cowneil of Industries held ac Karahi in Segtenbor, 1949 delaxed

In April last geasi, the government of Pakiso tan annoureed that Bakistan wotld weleome torelgn capital soeking investment rom a purels inauso trial and conome objectite and not claining ang 
othex speoial pxivilege. The govexnment also oto iered to give all reasonable racilities por reo mitance of propits eaxned on capital invested ins the coustry ooo

The government is avrare or a seeling, in certain quarers, that poreign capital is not essential for the industrial and economie develo opment of Pakistan. This opinjon is obviously based on the as andption that there is enough of capital in the country and thet 211 that is ise quired is to remove the sevexel handicaps irom which inres do not accept this iempoint. Thoy are setisiled. on the information a viable to them, thet is Pakigran has to take rapid strides in the matter or derelopment or irasustes it should obtaln inancial assistance pom aboat. It has been recognized by those who have made a stady of the genotra 1 conditions in uxdeveloped and underde veloped cowntries that the piranolat problems of devalopment cannot be solved, mithin a neasurable period of time. by reliance on the slow process or local capital formation." Such guatries mus look to the eapital makets aboado

Cextar saregnato hare ber taken, howerex, apprehend ing the exploitston of the cownty by porelgn ingestors.

Pakistan would welcome roreign capitah: nowerex, partoipation of nationals of Pakistan must be engred in adminiso crative and teehaicel services of the industries concerned. Gakistanis should oxdinarily be given the option to sub scribe to at least 51 pex cant of all classes of shaxe opo ital and debentures $2 n$ the rollaring industries:

a. Comente

b. Coal

1. Devalopment Plans Iog Pals stan forangton, D.Co:

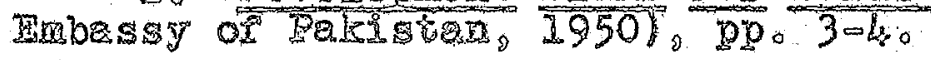


0. Cotion spinaing and wearing mi11s

Q. Pigh conning and fish oid

- Ceneration or electric power fother than hydro Q iectrel.

I. Glass and eration

g. Heary chenicals and aresturs

h。 Horals

I. Preserod and prepared coods

jo Pongra ascohol

k. Ship building

1. Swgar

管aniag and loather.

Whth regred to other industgaes, an opportwaity should normelIy be given to Pakistan nationals to subserdoe at least 30 per ent of all classes of shaxe capital and debentures. But if in either case, the gorernmer is satisesed that the indigenous capital is not fortheoming the balance with thein pror aproval mey be subscribed by roreign in vestoxis.

Apare from these conditon, which are necessary tor the sasery and political and economie wellobeing of the country, industries inanced and controlled by nationals of other countros axe assured of $\mathrm{x}$ ix and just treatment.

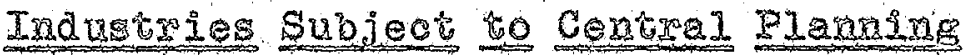

In two statements of industial poljey issued in Apri and Beptomex, 1948 by the Ministry of Industries, the 
governmen of Pakistan declared that the collowing indus tracs would bo subject to cencral planning:

Q. Arms and mustrons or wato

b. Cenen and cenent products

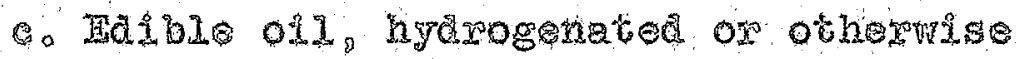

d. HLetrical comunicazions and broadeasting

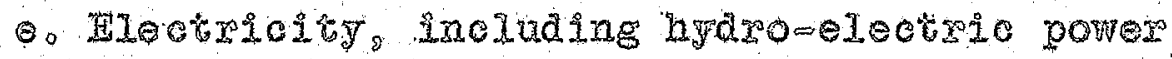

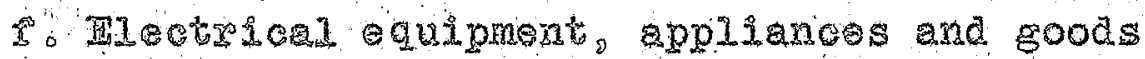

Go Gass and cerantos

h. Herey Gemials

2. Iron and steed

Jo Minchine tools precision tools, gauges, and work shop equipnent

k. Wouratures or heary engroering industry

1. Mnerals, Inoluaing sale and coal

mo Non-1ertous metals and alloy manviactures

no Reper, cardboard, and pulp

o. Petrolerm and minexal olis

9. Tharmeouticals; drugs, and light chemicals

q. Power and industrial alcohol

po Reserved and prepared roods

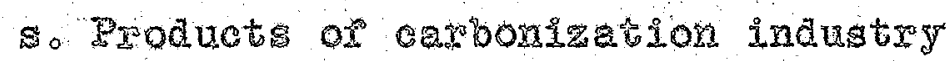

to Rubber menuractures

wo Solomirie and mathematical instruments

*o. Sed rish ana its products

wo Ships, barges, riter boats and Iightor

ta Sugax 
To. Tanned Ieather and leather goods

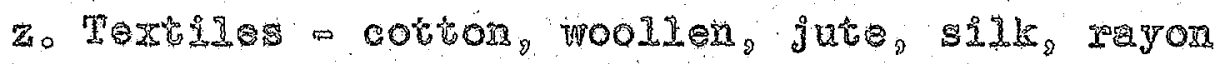
$2^{0}$ Tobaceo

The goresnom has ondy one object in piew, ana that is to do all it cen to help porwad systemate and planed development of industries. In order to ensure the indus trial development or Pakistan on sound lizes, it is necese sary that such devlopment should be carried out according to we loderiod and integrated plan. In prepaxing sueh a plan due acconnt bil be taken or the resources and reo. quitements of the country?

The gorexnent is fully conselous of the iqet that Stato acton alone, hoverer bererielal or paropeaching it

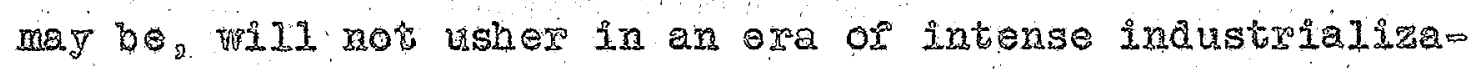
tion Indi play their part it phistan is to succed in building up a ballaneed econory. 
CEAPIPR V

\section{THDUSTRY AND - WTHING}

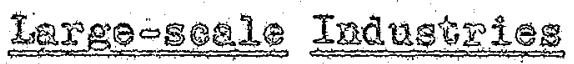

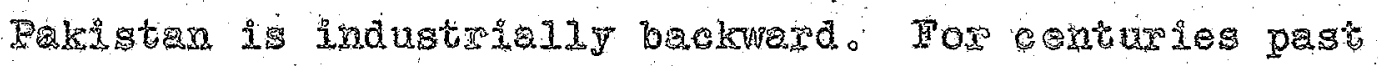

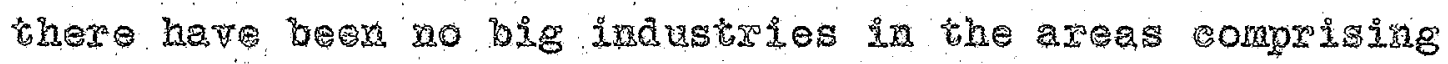
Pakistan. By and lasgo the economy of these axea has been

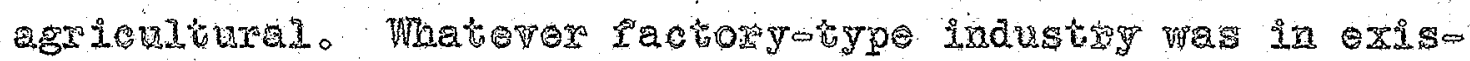
tonge betore partition was mosty in the band ox those who hate sitce migred Prom Pakistan. The result was that at

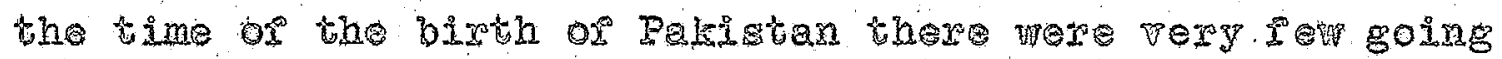

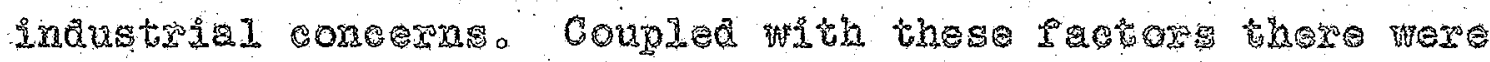

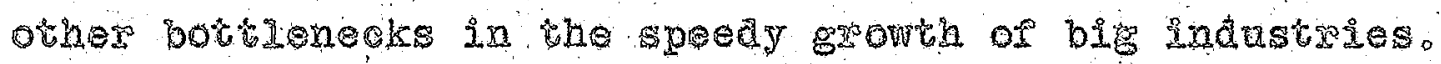
The Influ or rex ugess lack of acessary data and experio

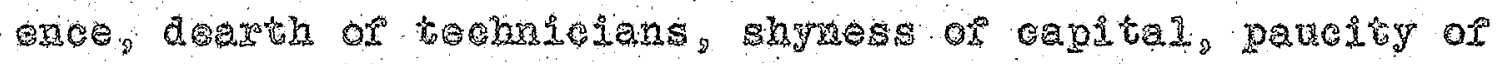

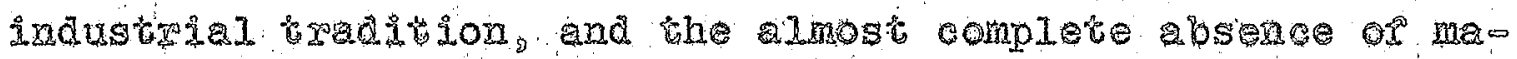
Qhinery and equipment were the main problens that the yows and und xaveloped country had por.

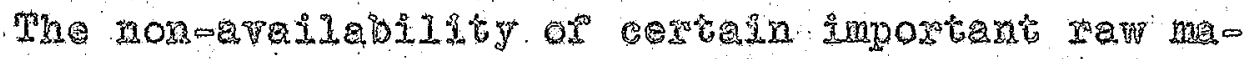

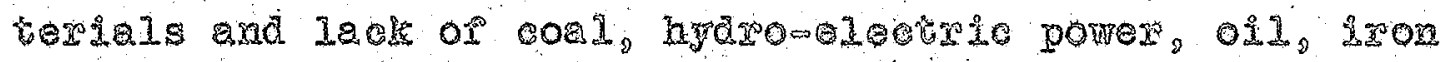

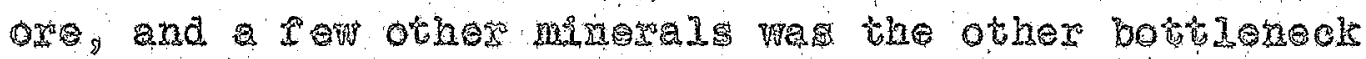

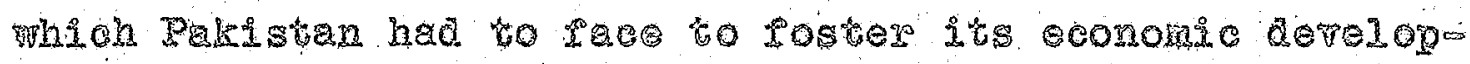
mentio 
The sope sop the Iadustrialization of the country. howerar, is pery greato Pakistan produces most of the raw ngteral requided tor the war ious consurex goods induso tries. Her potental tesources of hydro-dectro power are coornous: Her pteming milions cas protide the labor

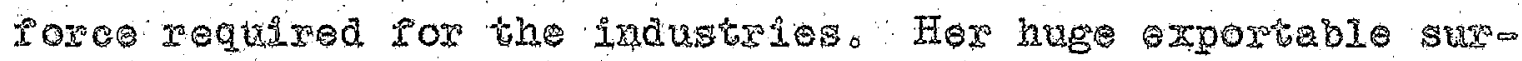

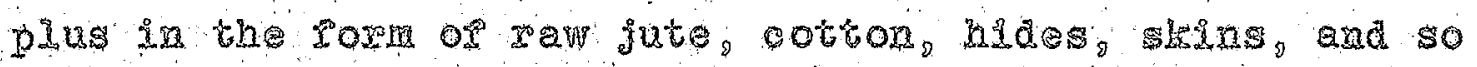

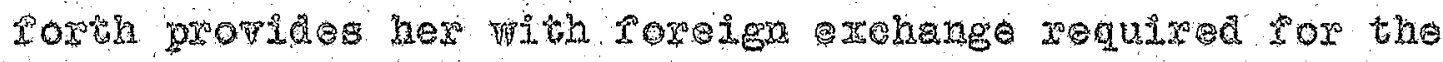
putohase of commodities and wetrices ia which she is hero sols derdoiento

The prospects for the tuture are brithe In the short pexiod of threo yearg, desplto inmurerable handicaps and difiouties, Pakistan has been able to take a Ilying stato

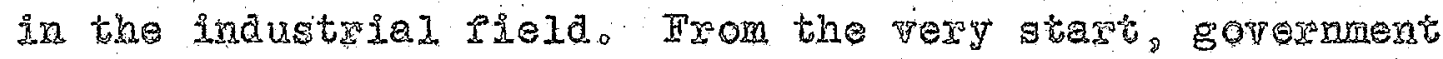
oxicials hare considega theit poremost duty to derelop the resources of the country at the greatest possible speed. Addresing the Canadian Parilament at ottand in Jwe, 1950,

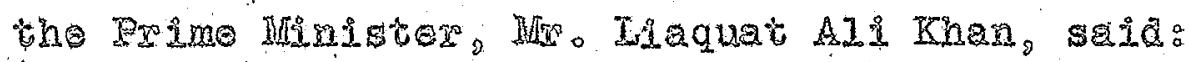

Fren in the days of our greatest antetios

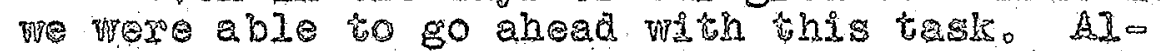
though moh remeins to be done, we are gled that the have been able to revitre aur trade, to plan Tor the detolopment of our ixy parsion and modernization or our agriculture and the weilization of our power xasouress: to keep ovi budgets balanead and to throus the gates wide open to pritato entexprse in our induso. brial a dere lopment.

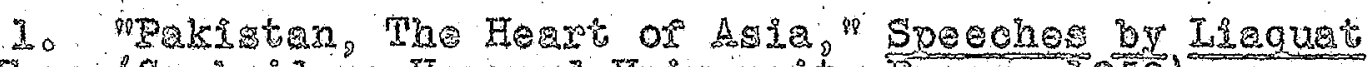
Al Khan (Cambidge Harora boiversiby Press, 1950), DP. $120=1210$ 
A bxies aceourt of some of the important fndustries is given below。

Jute: Pakistan and India bogether hold a wirual monopoly of the jute production of the world pakigtan aco count for 70 pex cont of the total jut acreage of the Indoopakitan subcontinent. Begides, a lerge part of Pakiso

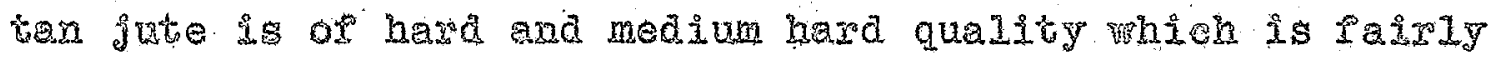
strong and contains a great deal or highy colored pibre suitablo sop the manuracture of high grade hessians. The qurago anual proaucion of jute is about six milion bales of 400 pownds ach. Jute is orton orlled the golden ibre of Rakigtan. Unfortuately, Pakistan has no jute mils. The entre erop therefore has to be oxported. Berore it ean be exportied it has to be pressed into bales. Preso ext arrangemants ror the baling or raw jute aro also inadeo quete.

The goverament is encouraging private ontaxpxise to establish jute mils。 Three privato partes have so pro come forwara to set up three small units in East Pakistar.

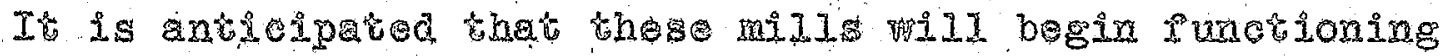
in the near tuture, producing hessian cloth and gunay bags, both of which are in great demand.

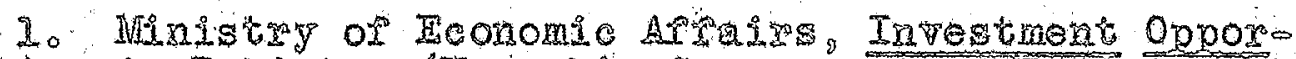

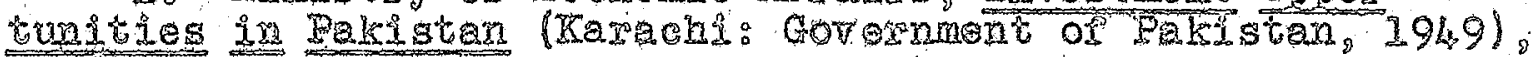
$p_{0} \cdot 6$ o 
As the xesponse prom priva industrolatsts for sebo ting up of jute mills has not been encouraging, especiany In the matter of setting up large mils, the goternment has declded to ostablish indtimliy live jute mils, each of 1,000 100ms. The firstis is expected to be working shorty 1 , the second by 1952 , and the third a year later.

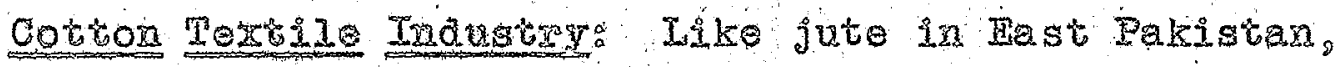
cotton is the principal comriercial crop in West Pakistan.

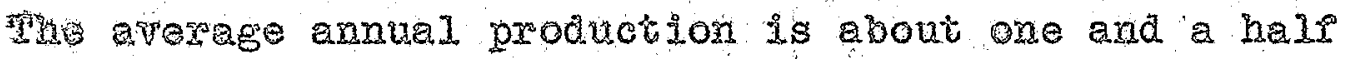
million bales of 400 pownds each. Hore than 90 per cent of the eotton produegd in Pakistan is of high grade, long staple Anexican pardeties. Whe standard staple length varies srom $7 / 8$ to 27032 ines.

As the time of paxtition, 24 ootton milis existed in the areas comptising Rakistan: aine in Wast Pakistan and rite in West Rakistan. The total production capacity of these wits comes to 103 million yards as against Pakigo tan's normal sequirement or about 675 mill lov jards pex andum.

In order to meet the oountry's arerincreasing demend por eloth, gorexnment ofpicials have decided to permit the axtabifibment of texcile mils with a total capacity or

1. Three Zears of Rakigtan (Karachi: Rakistan Publio

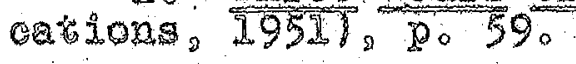

2. 200.950 


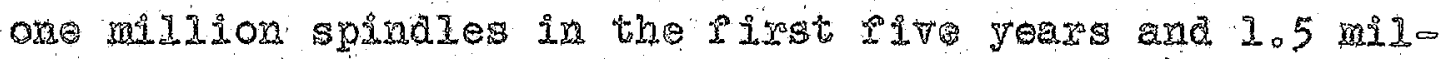

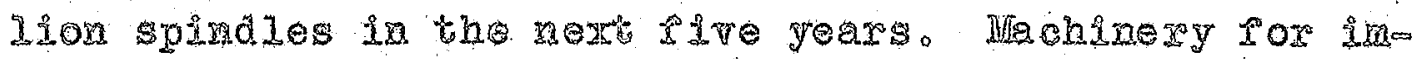
mediate derolopment is being procured prom varous conn tries, notably the United Kingdorn, OnIto States, and lately Jegario

Woollen Tetiles: Pakistan has abudant suppiles or raw wool wich is sultable tor manuracture of coorse mo terials such as blankets, rugs, and treeds. But she does not produce the wool required for the menurature of rine morited cloth and hosiexy yaxno

Balsistan at present has onls one worsted wil with $2_{2} 000$ worsted spindles。, A woollen wil with 4,000 spino dles has recently started production at Karahi. Howerers, it is decided to insta 1 some 24,000 woolien and 20,000 worsted spindles in the country by 2954055

Stgar and Alcolol Tudustries: Sugars cane is grom on 2 large sale in North West Frontien Prowace, East Bengal,

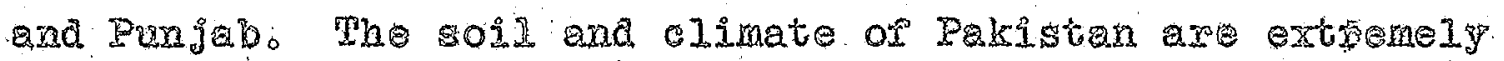

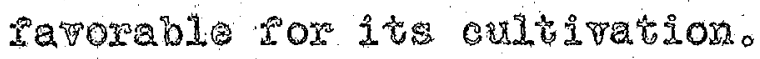

At the thme or partition there vere seren pactories produeing sugrap. Whe antues pxoduction capacity of sugar is stimated at 54,000 tons. Stice partition one new fae tory has been established in Noth Hest prontie Province

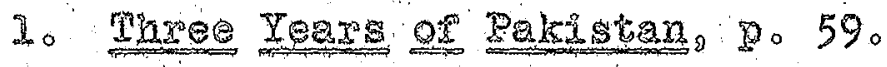


which has an anual capacity or 50,000 tons.

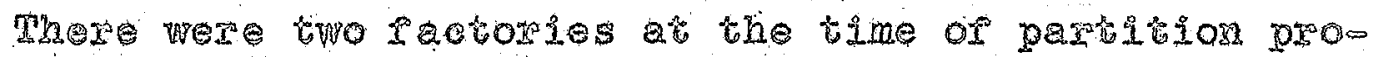
ducing doohol. The eapacity is estimated at 1.6 milion gallons of alcohol and 0.3 milion gallon or 1jquox per annoutho

Due to problbition in vajous provinges, and Iso due to the limited marke avalablo in Pakistan, the industro was hard hit. Howerer, in spite of 211 odds, the manuraocurers have nade an eloht to keop up producton.

Cenen: In Wost Pakistan thas aro sour cenent paro toxies heing an anual production of approximately 500,000 tong, whI in Est Palistan there ls only one pactory havo ing a produotion capacity of 75,000 ton per annum.

Pakistan has a surplus in cement, and it is being exo ported to countries in the Madde East and Indik。

Hegry Chomicals Tho consumption of heavy chomicals in a comaty is dependent on the extent of its industrial derelopment. In fact, the degre of industrielization or a cowntry is measwed by the extent of its consuraton of nery chemicals. As Pakistan is industrially backaro, the consumption of heary chenicals is rather limited.

Sulphuje Aeid: Sulphuxio acid is zighty colled one

1. Miaistry or Industries, Pakistan Industry (Karachi: Covernent of Beistar, 1949), 80.670 1950 ) The Second Tear (Karachi: Goremoment of Pakistan. 


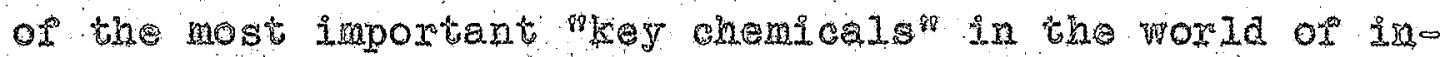
dustry. It is the rowndation bone of the chemsed indus try. There are only two small units manoacuring sulo phurate acid by the chamer proeess with a capacity or 300 tons per annum, tritorts are being made to ensure the in stallation of more plants.

Caustie Soda: Pakistan's anual requirements of causte. soda, which has extensive use in so moh industries Iike soep, Tegetable oil sering, and textiles, come to about 20,000 tons. There is, howerer, no caustic soda wait In Pakista Exorts aro being made to ensure lastallation of a castio soda wit by the earliest possible date. Soda Asin There is ody oxe soda ash plant in Pakiso ten. This is modern plant thith the capacity of 20,000 tons of light and heary soda ash por yearo This is gure oiont to meet the requirements of the country and leave an exportable surplus.

Herilizes: Pakistan being an agrieultural country the importane of tertilizers canot be orexerahasized.

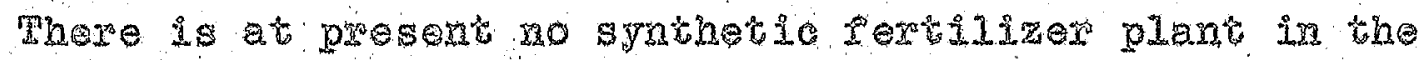

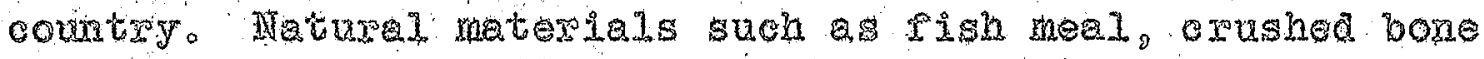
are the main fortilizars avalable for loeal wse. There axe serera 1 bonempushing mits in the country, but these

1. Three Years os Paksian, p.61。

2. Madstry or Industries, apo ejto, po 61 . 
Qo not neet the growing peztilizen need of the country. Realizing the importance of pertilizers por scientiric devalopment or agriculture, two technieal Missionsone Anglo-American and the other. Belginnoongere invited by the goternment or Pakistan to survey the resources or the coun

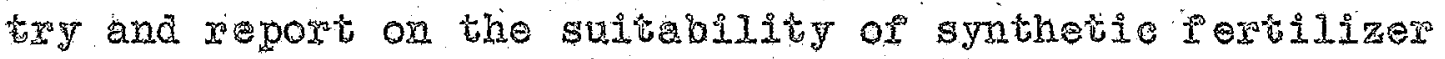
plants. Their surver reports are now wate consideration by the gorerument.

Tenning Industro: The annul paduction of hides is ostinated at rive milion pleces, thet or skins at elght

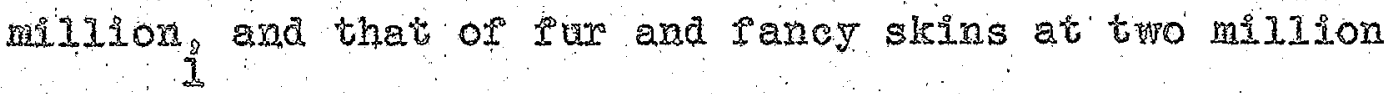
pieces. Thus Fakigtan produces large quantities of raw bides and skjns. There is aumer or small tannexies in Pakstan, but they are ill equipoed and are quite insureic cient ror the country $\mathrm{g}$ requirements. There is a vat seope

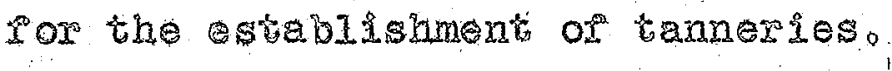

In ordex to develop the taning industry, the gorern ment decided to six taxets por the establishment of raxid

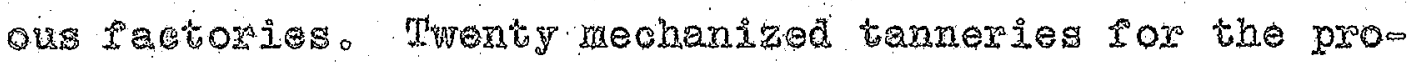
dut for or sole leathex mith a dejy soaking capacity or 1500200 buriato bides in beh tanery and 25 mechamized Gandex of uppes leathex with a soaking eapacity of 200 cow hides per day la each tannery are planned to be estab Iished auring the next five years.

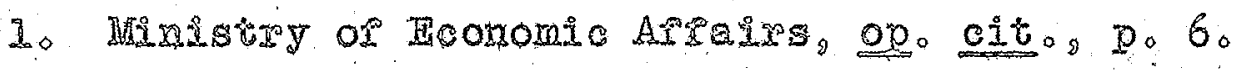

2. Hinistiy of Industries, epo ojto, po78. 
Development of other Industories: Whith the assumption or sesponsibility for the planning and dewelopment or 2 ? major industries (see the list on pages 62 and 63 , ante).

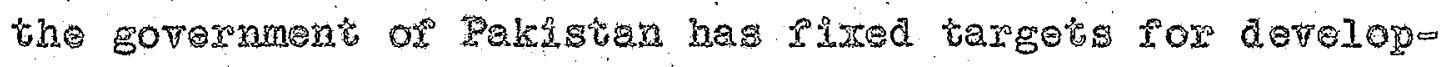
ment of raxious industries and ail possinle erfort is boo ing made to achlere these goals.

\section{Cotzage Industries}

In a conntry such as Pakistar where 85 per cent of the peble are dependenc on agriculcure and Iive in villagos. cottage industrieg have a special sighisicance and play a thal role for the national oconomy of the state. On aen count of her industrial backwardness, as has been seen. Rakistan is derieient in a largo number of man actured goods. This dericiency, leme in part, can bo rade up by the products of the cottage industries Woteover. the establishment of largeoscale industries which is now being stivalated through pardous mean by the gorermment will help ourtail the need ror inports of extain classes of goods. Difricultes such as searcisy or capital equipment. shymess of money capital, lack or industrial experience and technical skill in the establishment of lengesseale ind dustries, horerex, would take some time to be gleared wo The systematie organization and deralopment of cottage

1. For a detaled diseussion, reres to Hinistry or Industrifes; op. eis. 
industries would provide ar immediate and largely errectire golution, Insmoh the mohinory and implenents required

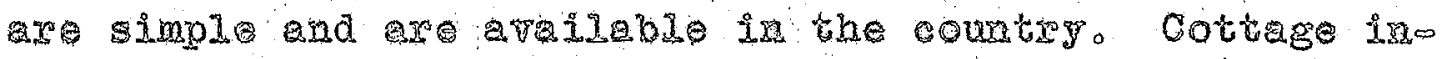

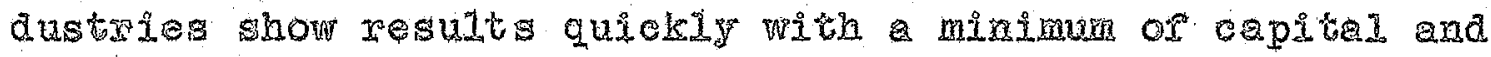
equipmento

Broblems of the Cottage Incustry: The financial rew souxees, in any, or nost of the actual and potentid cottage workers axe very meagre Finanelal asistance is theretore foquired par the purohase of implements and rew materials and for the maintenance of the worker and his samily until the disposal of the rinished products of his labor. Lete of suitable agencies for the rinarang of various cottage zadustries is one of the most serious obstacles in their derelopmant Tery prequenty it results in the exploitation of the workex by midalemen who usually supply raw materials on crept and purchase the products at ridiculously low prides. Due to his rinencial dependence and his ignorance. the wotser has nelther the hoice nor the abillty to diso pose of the goods at reasorable prices indepexdenty of the middiemen and is thus ritutuly reduced to the status of a

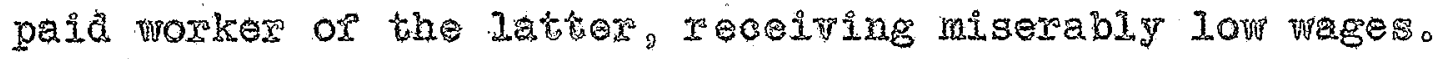

Another serious dipriculty experieneed by the cottage morkere is in tesper to the marketing of his products. The maxering costs axe very high, for the magin botween the price paid by the consumer and that realized by the. producer is very latge. The sale of goods is not an easy undertaking。It requites a derinite skill as vell as 
adequate knowledge or maxeting conditions It is thereo rore 600 much to expect that an oxdinary, illuerate, isoo latsd cottage worker with limited, is any, wources moudd be able to dispose or bis goods in an exicient mannex. He my bo good producer but; a to his Iimitations, delinicely is bad salesman. So he is exploitod by mide demen。

A sexious difriculty in connection with the marketing or cottage products is the lack of wirorm quality of the axtales produced. The uncertainty about the quality of the cottage products renders their paysical examinaton by the consumer necessaryo This tends to limit the market to the imnediate neighoorhood ot the producer.

Measures Hopted by the Centrel Coogrment: The Mnis Gey of Industries doclared while addrasing the Rakistan Comeil or Industries held at Kaxeni in Septembex. 1949:

Centre is ritally interested in the dorelo opment, on ata oxderly basis, of cottage induso tistes. The interest of cottage motrex mis not. I can assure one and 11 , be sacrifice, becase the Centre is directly responsible por the de relopment of large seale lndustries. Thexe is no reason why development of the two should not go hand in hand in Pakistan. Centre is vitaldy in

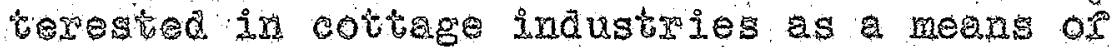
absoring the hundred of thousands of rexuge artisans who bavo migreded to Pakisten.

Acoordingly in oxder to work out a coordinated plan. or derelopment for Pakistan as a wole, it was decided to

Lo Development Plans por Pakistan Washingtong $D_{0} C_{0}$ : Mabasy of Pakstan, $19497, \mathrm{p}_{0}$ 10。 


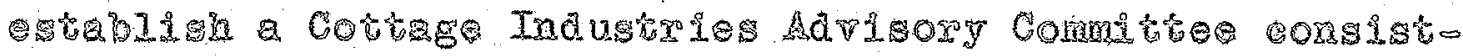

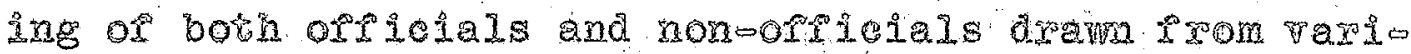
ous ragions and epsesonting parious industries. The tunctions of the Commitse are to organize and develop ame 11-\$cale and cottage industros, to assist in the meto koting of their products both in Pakistan ad abroad, and

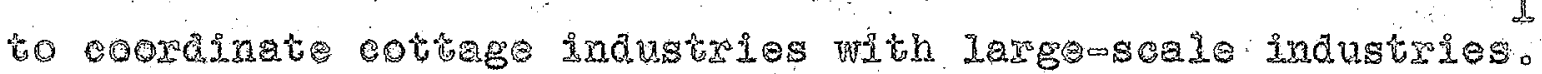

A Cottage Industios Directoreto in the Deparment of Supply and Devalopment has bea established. The sunc.

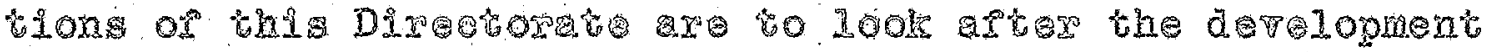
or cotbage and smallogcale industries, to provido assigo

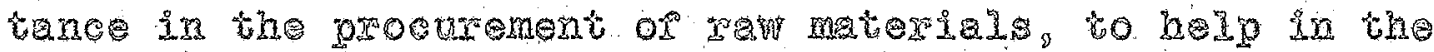

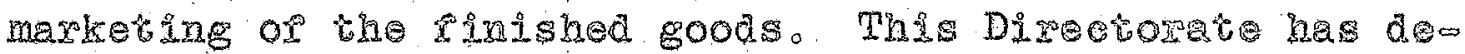

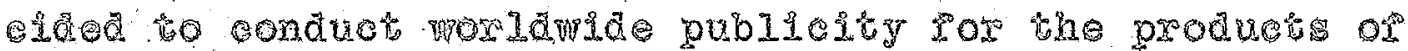

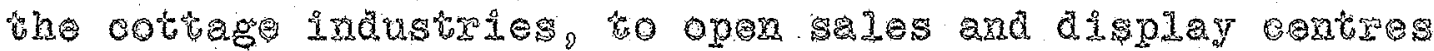
lone zt London and another a New York's and to open show rooms in other diplonetic orrices oterseas.

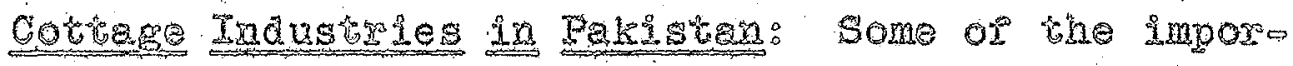
cranc cottage industiones are lister below

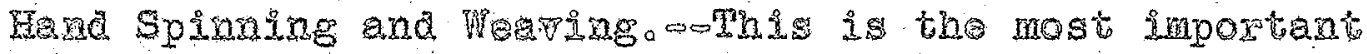
cottrge industry and is caried on al1 orer Pakistan.

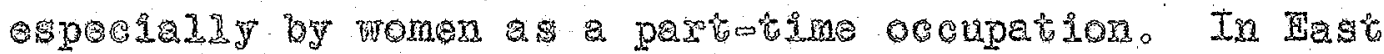
Bengal some women ean their ilving prom ito by raking it

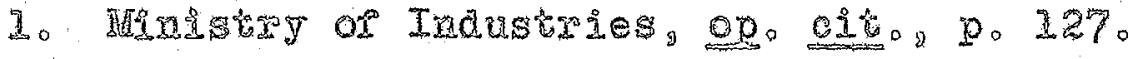
2. IDId。. 00.1290130 . 


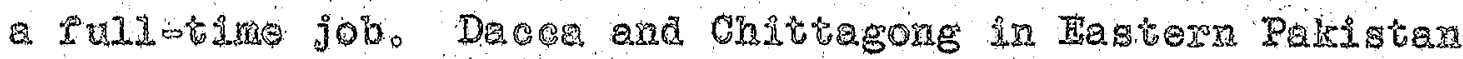

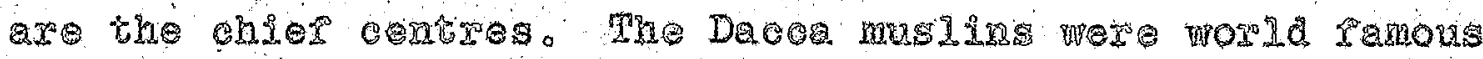

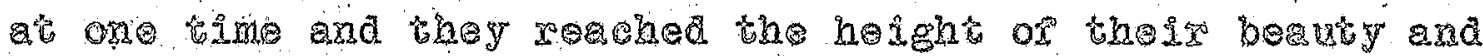

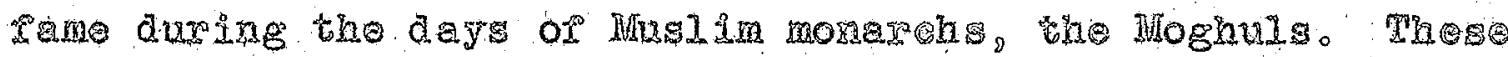

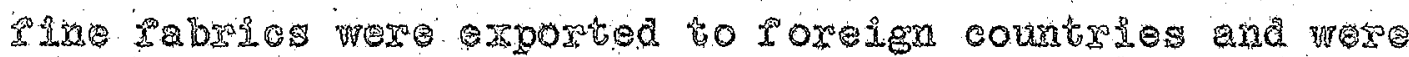

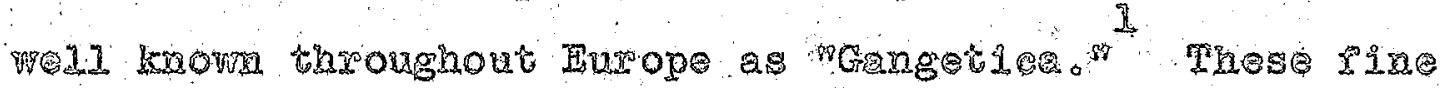

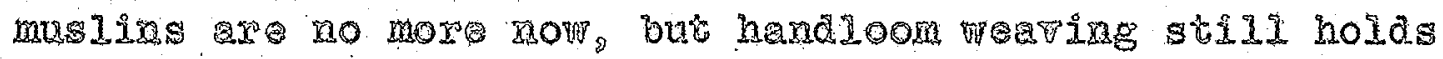
an smportart place in the pxorino:

Wool Industoy ond

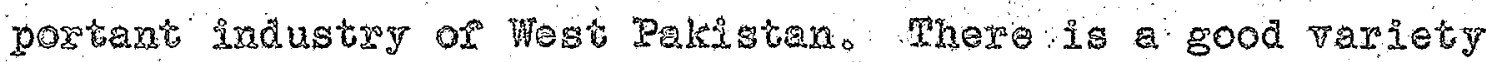
of woolden products such as rugs, cappes, shawl, and boratso

Jute Spinaing and WeavingooIn East Pabjatan jute is grow in abudanco: while the bulk is exported, a considero able part is turned lnto cloth on a cottage basis.

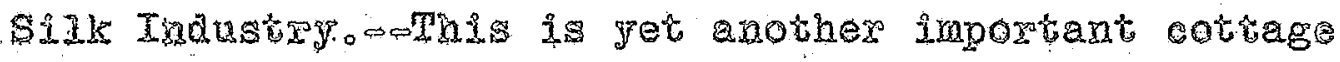
Industry of Pakstan. The parieties of silk loth produced are area, caps, and thbas, table corers and curains.

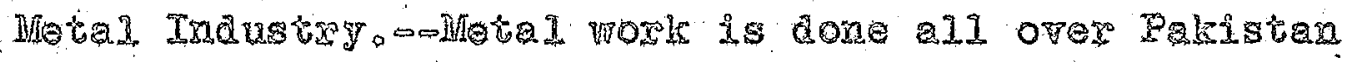
and constrty or work in brass, boll motal, coppor, iron, gold, and silver. The majority of the poprlation uses ret.

Woodmork. mollodmorle ranges wom simple photo irames to

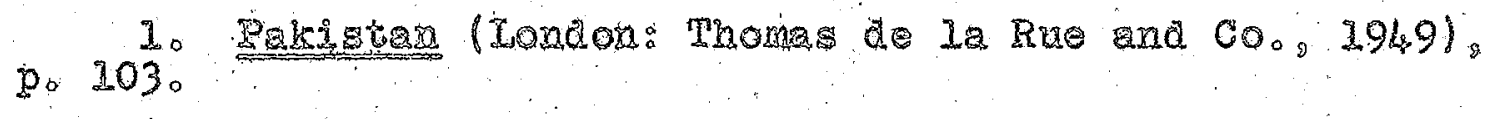




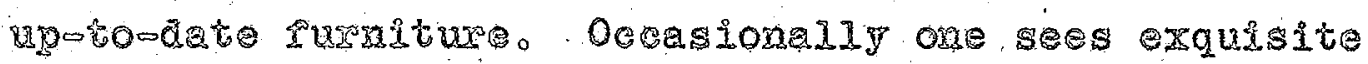
caring on surniture, windows, scresni, and doorwass.

Tanning and Leather Goods.with Poxms an Important ltem on the cotage industoy isto side by side with rough and partal taning there is high-olass taning and chrome Leather merifactre. Shoes, Slippers, belts, purses, sultcases, and other goods axe also produced by coto tage workers.

In adation to the abore, there is a dumber of other

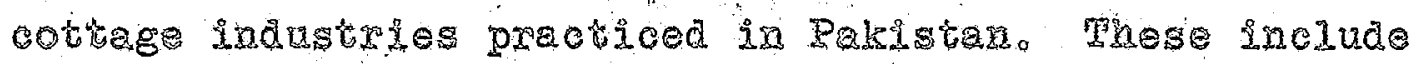

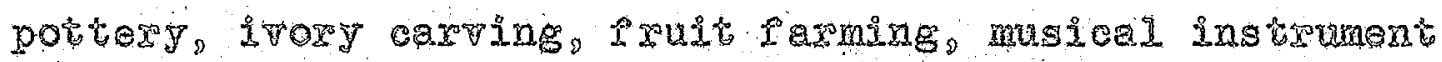

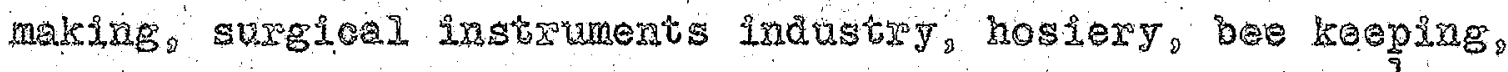
soap mokitg, oll pressing, glass bargles, and the like.

\section{Poner Resouros}

It ds atometie that there car bo no industrial develo opment without notive power. The normal sourees or power

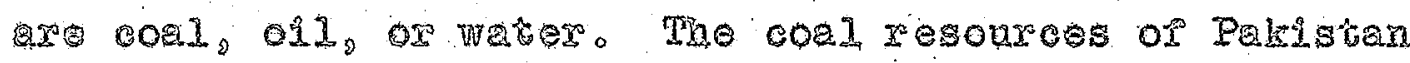
are limited. Coal doposits are not large enough to make hers 302

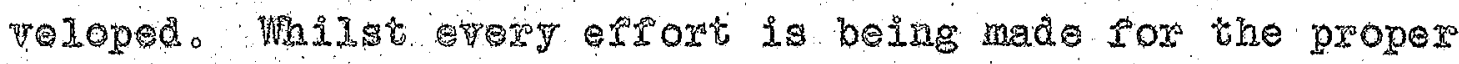
utilization of these resoures. Pakistan has to look to other sources or ponter for rapid and intanstye development or the country. She will have to depend on her water power

1. Hinistry or Industries opo eito, ppo 131-140。 
cosoupes as she has fast potontialitid fox the genexaton

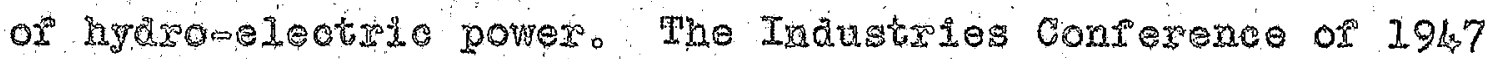

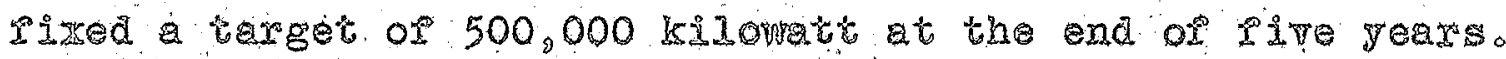
A Central Bugineoring Authority has been set up pox initio Qting, serutinizing, coorainating, and pressing poward sehenes sor the control, regulation, and utilzeton of the weter and power xemources of the country. The total capacity under development; by way of scheres now undexpry. $1 \mathrm{~s}$ orer 77,000 ki10wato

As ror ojl, the requirements or Pakistan at the pros ent level of consumption axe 150 millon tons of which 2bont I5 per ent is produced indigonousiy and the rest im ported, mosty from Iran or other Hide Hat couniries. The prospects ror increasing the indigenous production axe bright. The geologlod surey of the country which is in progress will holp the position, it is hoped。

\section{Mineral Resounces}

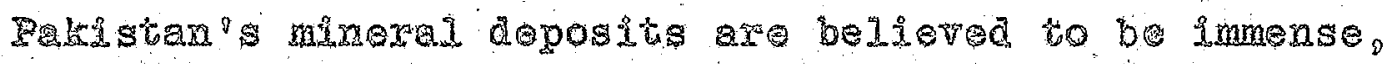
though at present a pexy mall quantity of the panerals is

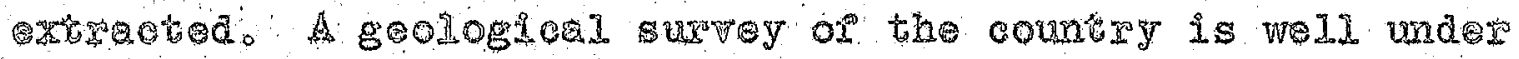
may and, a resul, mery valuable deposits are expected to

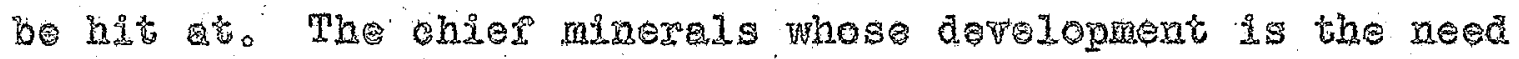
of the day axe the following:

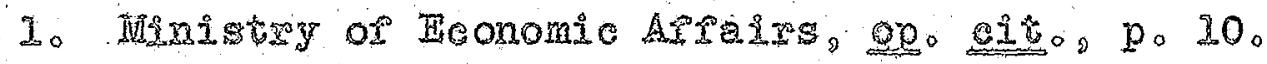
2. Loe. 210 


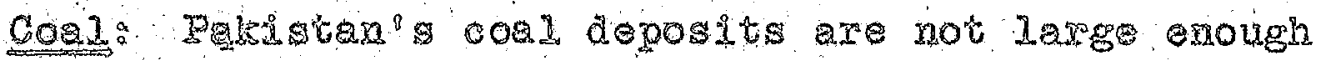
to mak hos sels-suricient and, surber, they have not beer ully developod. Her ind genous production at preso ent is ouly about 350,000 tons as against an annul teo quireran of 2.5 million tons. consagunty she has to depend on imported conl.

Oil: Undike the Unitad States, the oil is the propero by of the gorernent of Rakistan: tho oil conossions are granted only to companies or repute. At presant the proso pecting and mining of petroleum, ineluding natural gas, is being caryed on by two companes. 11) Atrock 01 Compary and (2) Burmah 0i1 Company. Lto.

The total production or oly was 426,000 bargels during 2948 and 824,000 barrols during 1949. This output does not place Rakigtan on the oll mep of the world.

There is only one repinery in Pakistan at present which mas constructed by the Atrock os Company at Rawelo puid. This refirerg has a meximutr retining eapacity or 4,500 bagrels of erade oil per ay.

Chromite: Chromite or chome ore, rrom which is ob toined the meth ohomiwn, is used as an alloy por the

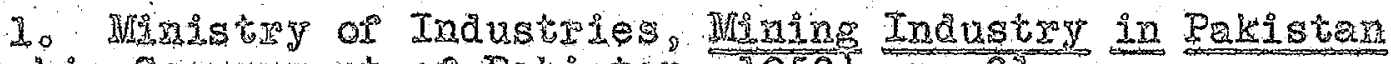
(Karachi: Government ar Pakistan, T950), po 330

2. Ibido, $p_{0} 20$.

3. Los. 


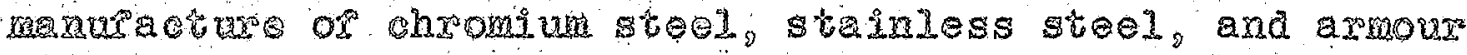
plates. It is fow in bunance in Pakistan. The mineral

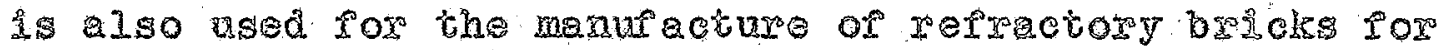
Turnee lining, as well as in the dyeing industry in eleco trieal and marine ongineoriog, and in many other ways

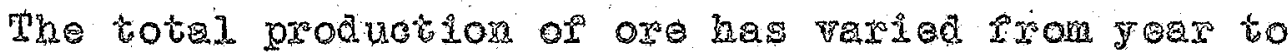
Yrear. In 1948 the producion of ohrone ore was 18,000 tons. and during 1949 about 15,700 tonso The enciro quarity is

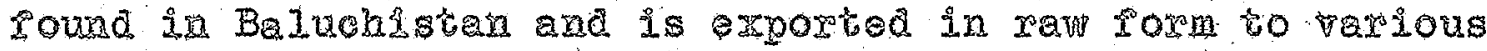
courtcies wuh as Prglad, Anerder, and Sweder since there axe no racisties in Paktan por replning this ore.

Antimony: Antimony ls a metal uged it ehenioels and in metallurgy ror Irapartig bardess and fusibility to vario ous aldoy such s igpe metal, insulated wires, lead

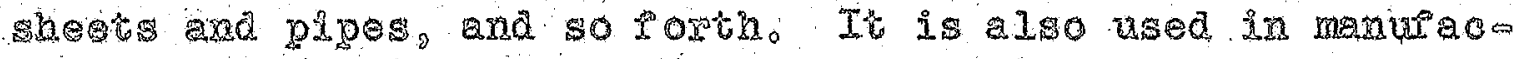
turing sasety matohes.

During the Second World thar some work was done on antimony deposits in Pakistan, but these oporations have bera suspended sine partition. The total production duxo 2 Ing 1947 wes about 400 tons phe question of working the depostis on connescial bass is recolving the attention or the gorernment:

1. MIndstry of Industros, Mining Industry in Pakistan, DD. 4304040

2. Ibido. 90.42430 
Silica Sand: Silica sad is employed in mortar and coment, and is used tom making broks cor the lining or

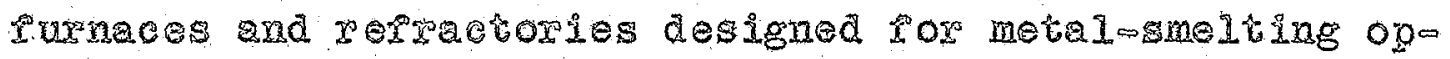

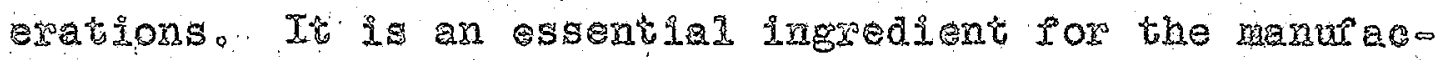
true of glass and partous types of paints and chemeals. This sand is round In tarous areas of llest Pakistan.

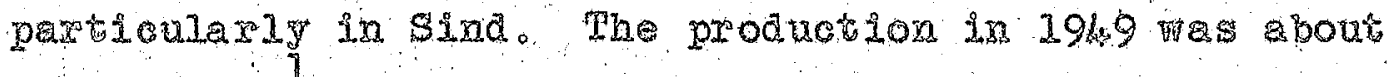
I,600 cons. The method of production have so tar been pxitation

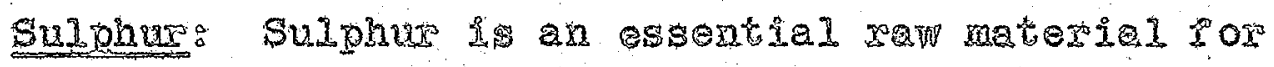
chemical and varioug orher industries as it is one or the chier soures pom which sulphwie acid, the mast important single comodity in the chemien industry, is derited. Bo sides belng used in the monucture of chemoals, sulphuxic

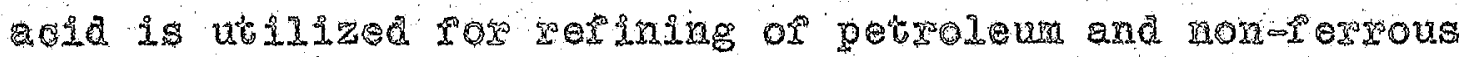
metals. It is also usad in the mavecture of explosives. pelats, colors, zagon, and so roxth: and it is required in paper, pulp, and wbbes industros as well as being used in rext11iters and food products.

Though sulphug deposits octux in rang places in West Rokistan, the principal deposits whoh wexo wod during

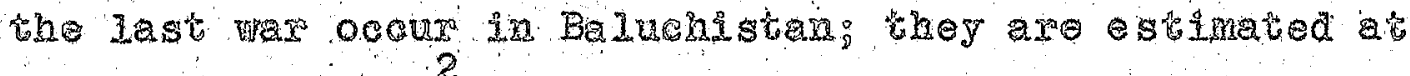
ebout 50,000 cons. The question of working them again on

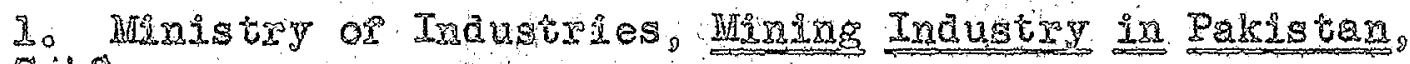
Do. $47 \div 8$ \%

2. Ioje. 20.48040 
Gommarelal lines is wora consideration by the government.

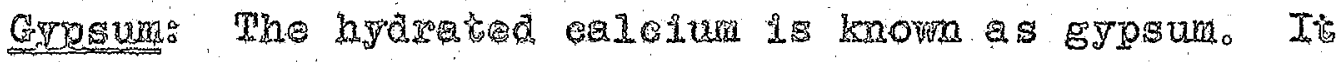

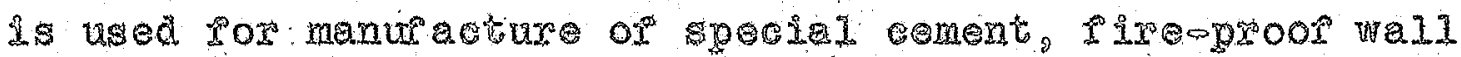

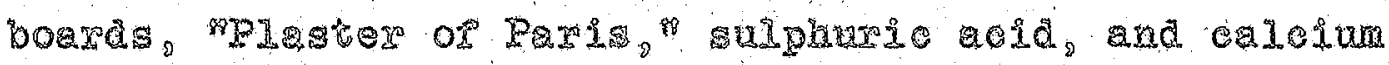
sulphate. It is also ased a pertidier and a a insuo lator geinst heat and cold in modern hores.

In Fakistan, gypon deposits oceur in Horth West From tier Province, the Pujeb, and Sind, The resexves, which are nathy located in Eujab, tocal more than 30 million tons. The total annual production is about 16,000 tons. The question or wtilizing this raluable mineral as a Lertilizer is under consideration by the government, which has secured the sexpices of a per poreign tochnical experts corthis purpose.

Limestone: Limestone is the stone with calciun care bonate which, wher buraed, tores white eustio earth lnow as lime. Lime stone teds the lime iadustoy as well as the coment industry. It is also used fox the manuaco ture of chajk and calciur cabla, ad as a building stone. The total annuel outgut during 1947 mas 342,000 tons whil in 1948 it stas 356,000 sons. The known pxoduction of Iirostone duxing 1949 was 279,000 tons. Ifost of this is used by e ement actories within the country.

1. Maistry of Industries, yning Industro In Pakistan. $28 \cdot 4.6-47 \%$

2. IBId, $20.4 \% 490$ 


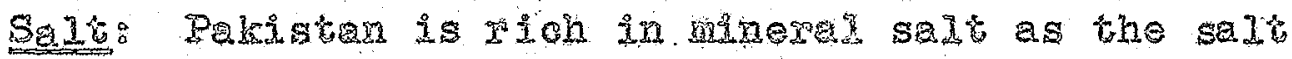
mines in Pujab and North West Fronter Province produce about 60 mifion mourds of salt every yearo The salt prom these mines is ox rexy good quality, weary 99 per cent puxe sodiun chloride.

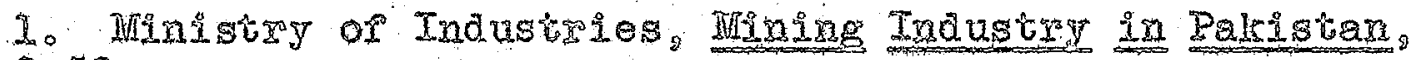
ppo 49052。 
CHAPTER VI

LABOR AND EUPEOYUENT

\section{Hetures ox Pakistan Deosom}

Pekistan is essenteIIy an agroultrial countey the bulk or whose poople live and wom in tillagen Techacal

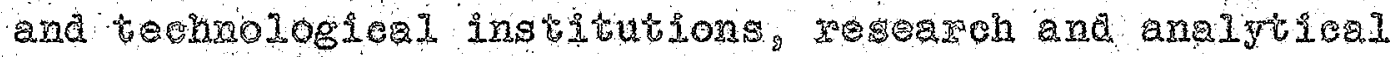
Leboratories, oredit and service aganeies, organizations of capita and labor, Iabor welrare, and industral pelations which one normaly associates wh an industrally developed country hate yet to be opanized.

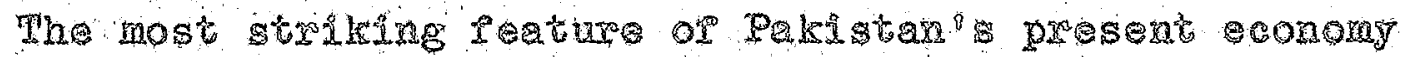
is the mitred contrast between its gast natura resources

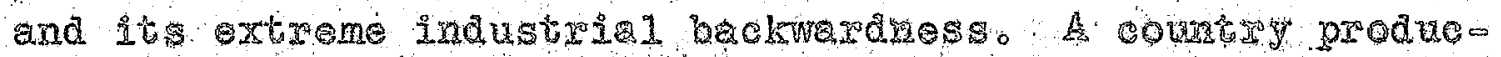
hag near 15 per cent of the world"s producton of jute

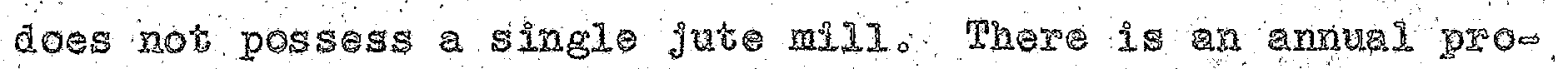

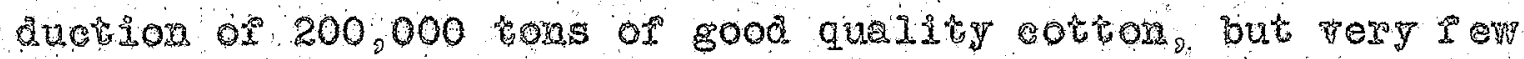
mills to utidize ito

\section{Labos}

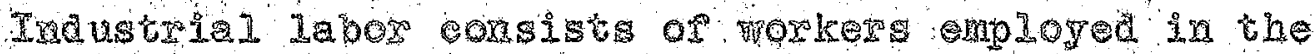

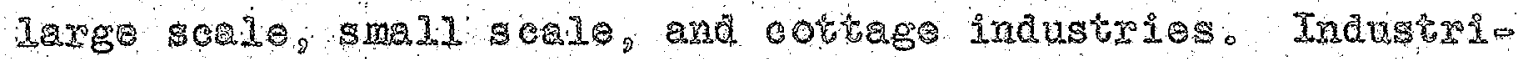

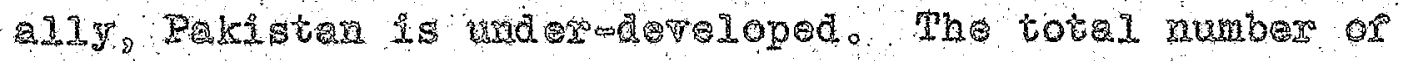


Industriel workers, thereiore, is not large, As a result, Labor does sot ocerpy that position or lmportance in the conony of pakistan which it does in the more industrialized countries. It is also not well organimed。

An orerohelning majority of people dopend on land.

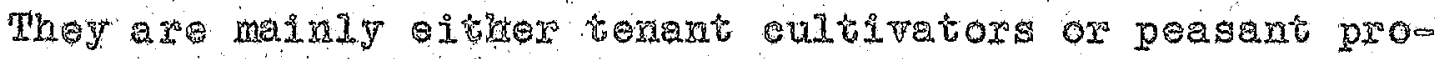
pxietors. A relativity much snallex number is employed as

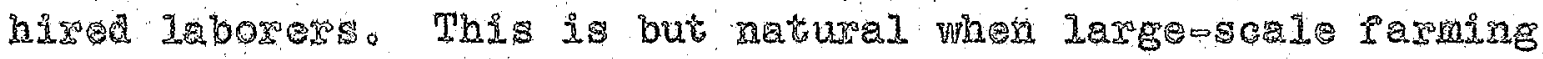

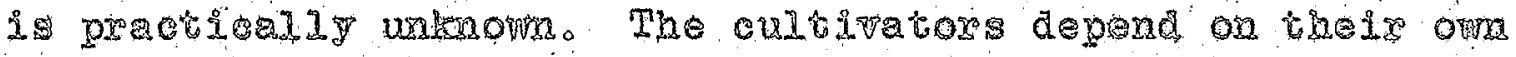
ramily g labor and take on some hired labor only in the busy. serson, asuelly at harpest.

Less than I pex ceat of the total population of Pakism

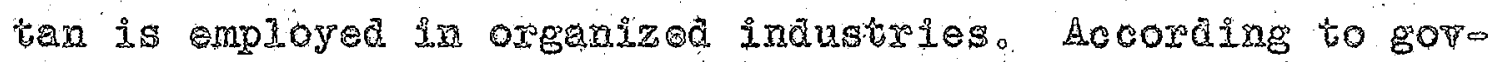
erment estimates, the amber or industrial workes in Pakiso tan is just oray 662,000 . The pollowiag table show the strength and astribution of labor employed in the rarious catogories.

Imployment: Dotailed statistics ror employnent for uno employment) are not arailable. It is dipticult to assess the number ox landess agxicultural laborers and wage earnexs employed in quasi-aggioul cural, home and cottage industries: but there is no doubt it rus into meteral milizons Horow over, gracultural operations ar seanon in charactes, and the agrieultural workexs do not find enough work to keep ther busy all tho gear zound. There is thus a great deal of pase tial wemplogment amosgst. agrieultural morkes eren in normel times. In a country where the orexwhelmixg majoxity 


\section{PABE VII \\ INDUSTRIAT IABOR}

Type or employment

Ho. of workers

(in $000^{\circ} \mathrm{g}$ )

Working in pactories subject to tho Hatories Act

Rajivags

Tea atobes

Ihereatid le marine

Dorks and ports or Karahi and Chitigong

Inlend water and other transport

Mines

ox people lite on land, where nothod of production are printtive, and where grieultural workers gemein partally unenployed, how low the standerd or living of morkers would bo ta mery woll be pigualized.

With the pextition of the Indo-Pakistan subeontinent and the etchange of population which took place the pressure of populaton on land and also the rolume of agticultural waene ploymer hare substantialy increased. This exchange of

1. Basie Fects about Paristan Karach: Government of Zakistan, 1950$) \frac{1}{20} 18$. 
populetion has also resulted in a consdarable ner increase in the number or gotbage workers in Pakistrin. They consist of atisans, tochnolans, and other skilled and unstilled workess. The tolwa of vaemployment amongst them is con sidexable

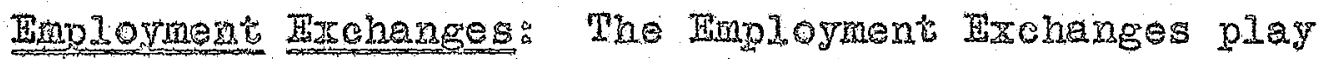
an important part in tecking the problems of anemployment. These were originally intended to asist resetrienent of demobilized soldiexs and discherged war workers. With the Inplur of milions of destitute refugees from across the border, the soope of the Exiplozment Exchanges was widened to include the sesettlement of refugees along with exsestrice med。

Io the wole of Pakistan, thexe are 23 Imployment Ho 1 changes, distributed as sollom:

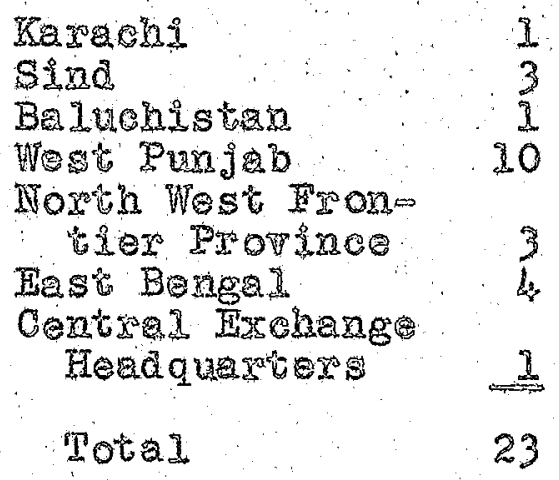

In the pexod August, 1947 to December, 1948, the Emo ploymert Hohanges registered 288,000 woxkers or whom 93,000

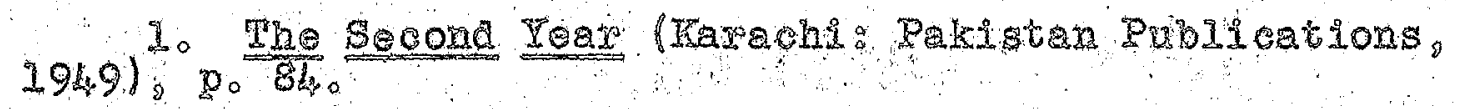


(about hat being rerugess) were pound mork. I

It is proposed to inerease the atumero or these employo rent exchages in Pakistan with a wew to roking the serriee aralable to a larger proportion or the population.. The longotern plans include the covering of the whole op the coustry by a network of employment exchangen, wh an oxo tieo in each distriet and inportant subdigision wh the pollouting objects:

I. To give Pakigtan an intograted nationmide employo ment serpice.

2. To eliminat the otis of jobbers and nidalemen from which the reerultaent of labor suriers at present. by providing an impartial sexpice to both employers and woxkers.

3. To help industry in obtainiag skinled labor and technielans.

bo. To help in the location or industry by giving deta segarding apoly or labor to prospective industro 2113ts.

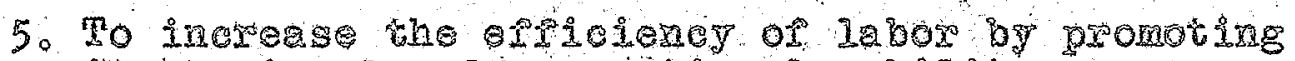
Its regional no oceapational mobility。

6. To prepare a max power budset wox the nation so thet the best ma be med of the aralleble xesources.

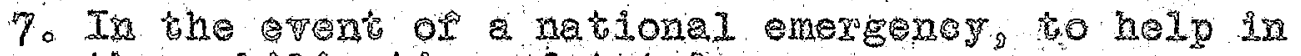
the mobilization of total mata power.

8. To help morex rase their standar or Isting by introdueing and administering a schene of soojal instance

2. Richard Symonds, The Making of Pakiatax Itondon: taber and taber, 1949 , po 188 D. $127 \%$

2. Pakistar (London: Thonas de 10 Rue and Co. 1949), 
Hages: The majortty of the workers join industry as labores on holpers, and axter gaining experience or ino dustrial technque ise to the highor categoxies of senighilded, skilied, ard highIy skIIed。

Thexe axo two systems of payent pxeralent in Pakistan, one of time and the other of piogeres the former ays tem connotes that mges are pald in accordanee with the time lement, joso, daily, weekly, or mothly. The labtex may bo dexined in terns of arantity of work done. The mafority of vorker in Pakistan are employed on the time rate gystem. The general rate of wages in extain or the oxgan ized industries is giper in Table VIII.

In a period of rising prices, the wages of labor folo low the xise in the cost of lingo There is, howerex, a time Iag in the begiraring at eary stages. But as the ino tationary spiral gots well on 165 way, the rise in wages nore ox less keeps pace with the rise in the cost of lining。 The norenents of wages in Pakistan have generally been ora these Iines.

Fom Table VII it mill be observed that vages pald to

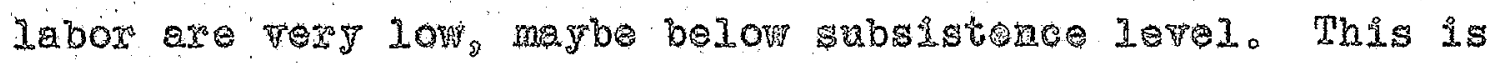
go berase the laboter are not well organized, the numbers emploged in largescale industry are rather small, and the Tolume of unemployment ig rexy large oming to the great ino Pux of reingees. It was not possible rox them to secure Hages which, wder the prevailing level or prices, right be regarded as uncesonebly high。 mere wes, thezerore, no 


\section{TABLEF VIII}

WACE RATES IN CERTATN INDUSTRIES

\begin{tabular}{|c|c|c|c|c|c|c|c|c|c|}
\hline \multirow{2}{*}{$\begin{array}{l}\text { Categories } \\
\text { os workmen }\end{array}$} & \multicolumn{2}{|c|}{$\begin{array}{l}\text { Rajiwas } \\
\text { per monith }\end{array}$} & \multicolumn{2}{|c|}{$\begin{array}{l}\text { Tremmays } \\
\text { per month }\end{array}$} & \multicolumn{2}{|c|}{$\begin{array}{l}\text { Gerasab } \\
\text { industry } \\
\text { per wonth }\end{array}$} & $\begin{array}{l}\text { Texille } \\
\text { per dey }\end{array}$ & \multicolumn{2}{|c|}{$\begin{array}{c}011 \\
\text { per month }\end{array}$} \\
\hline & $\mathrm{M} / 28 \alpha_{0}$ & Mas & $\sqrt{480}$ & Hex: & 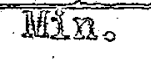 & NESO & Mno Mas。 & MISO & $\pi \operatorname{dr}_{0}$ \\
\hline Unskili@Q & $\frac{26}{7.70}$ & $\begin{array}{l}37 \\
10.95\end{array}$ & $\begin{array}{l}80 \\
23.70\end{array}$ & $\begin{array}{l}100 \\
29.65\end{array}$ & $\begin{array}{l}58 \\
17.20\end{array}$ & $\begin{array}{l}66 \\
19.55\end{array}$ & $\begin{array}{ll}1.8 & 208 \\
0.45 & 0.75\end{array}$ & 93.78 & $\begin{array}{l}38 \\
11 \cdot 25\end{array}$ \\
\hline Som $\circ \sin 11$ d & ${ }^{38} \cdot 1925$ & $\begin{array}{l}45 \\
230.32\end{array}$ & $\begin{array}{l}90 \\
25065\end{array}$ & $\begin{array}{l}340 \\
42.50\end{array}$ & $\begin{array}{l}66 \\
29.55\end{array}$ & $\frac{113}{33} 50$ & $\begin{array}{ll}2 / 8 & k \\
0.75 & 1020\end{array}$ & $\rightarrow 0$ & \\
\hline SE 1100 & $\begin{array}{l}60 \\
87.80\end{array}$ & $\begin{array}{l}150 \\
4050\end{array}$ & $\frac{150}{4.600}$ & $\begin{array}{l}275 \\
82.50\end{array}$ & $\frac{113}{33.50}$ & $\frac{193}{57.20}$ & $\begin{array}{ll}4 / 8 & 5 \\
1035 & 1050\end{array}$ & $\Leftrightarrow$ & \\
\hline $\begin{array}{l}\text { Superedsory } \\
\text { ntars }\end{array}$ & $\frac{225}{36.90}$ & $\begin{array}{l}500 \\
14800\end{array}$ & $\begin{array}{l}160 \\
4.7 .50\end{array}$ & $\begin{array}{l}300 \\
88.90\end{array}$ & $\begin{array}{l}162 \\
48.00\end{array}$ & 24500 & $\begin{array}{l}175 \text { per mo } \\
51.95\end{array}$ & $\Leftrightarrow$ & \\
\hline
\end{tabular}

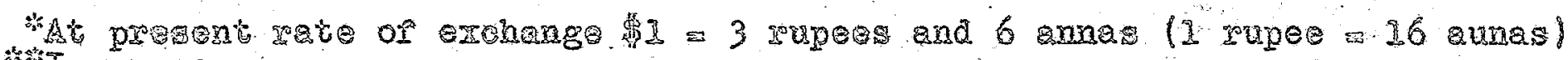
sis respees

1. Ministry or Industries, Industry in Pakistan Karachi: Goremnent of Bakistan, 1950), po 109. 
necossity or having a wge control to provent an undue rise

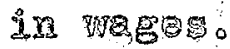

The workers bargaining power, which was already versy poor, surered a further weakening owing to the arwival in

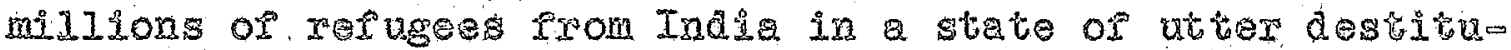
tion: and the wage rates, especially in occupations which did not call for axy stril ox previous training, tended to Tall below the subsistene lave1... The need por the imposio tion of control orex wage rates with a vew to exsuring a minimumage was obvious, and the govexnment was not slow to coognjz ito. The State protects the torkers through the Pament of Wages Aot whoh provides lox the prompt and time $1 y$ payment without nauthorized doductons. A minimum Wages Bill wheh provides rox rixation or minimum wges in sereral oceupations, ineluaing agriculture, is und the considexa cion of the Constituent AssembIy. It is the intention or the gotornment to help labos in obteining reasonable condio tions or employmento

Howe of Employment: The State has long discarded the laissezire dootrine which allowed the employers complete freadom to do what they liked with the workers. The Faco toxies Aet of 1934, as amended in 1946, prescrioes a maximum sbaboux wek. Gexexaldy eight hours a day are worked, but In case where workers are to be employed bor more than aine

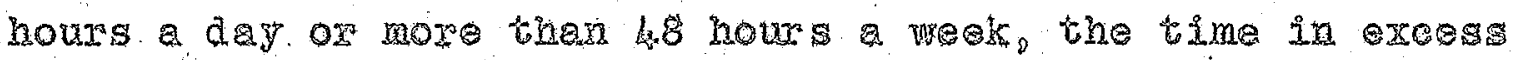
of the welly or dasty limit is paid ror ab double the ordinatyate or pay The ractories Act also makes it 
obligatory on the past of the employers to grant to workers with 12 months of sexvice at thoix erit ten days paid bolidays in a yearso

Employment industros, like other emoloyment, ia volres risks of acident resulting in personal injuries to the wormen. The Workmen's Compensation Aet protects the morkers against aceidents and makes tho employer liable to pay compensation or injury to the workmen employed by them.

Industrial Employment Standing Oraex: The employers can no longer dietate their ow tems and conditions or serom wo to the workes as the Irdustrial Empoment standing Ordors Act requires employers employing 100 ox more persons to rosmaly derine texns and conditrons of service in the ron of Standing orders and submit them to the gorexnment

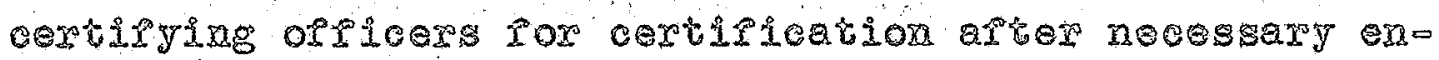
guiries and consultations with the worken's organzations or their representatios.

Industrial Belacions: There has not been much induso brial strite in Pakistan. There mero a fen disputes which Were prompty settled so that the number of working hours Iost was pry small. Since partition and to the ond of 9948 there were 20 findustrial asputes in the Noxth West Frontex Provine and Baluchistan. In Sind, howerex, there we 12 gtrikes involoing about 10,000 mozkes and a los of 22,000 men days. Iast Bengal had 69 strilses involring 
60,506 workinen and $105 s$ or 130,000 man adys.

The Industrial Disputes Act, 1947, and the Contral

Rules tramed thereunder proride mechinery por the sottlement of Industrial ofsputes. This consists or a Works Committee

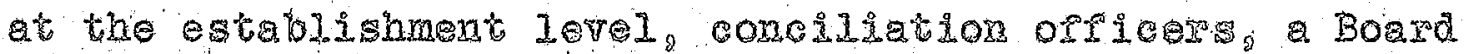
or Conciliation, Court or Irquiry and an Industrial Tro

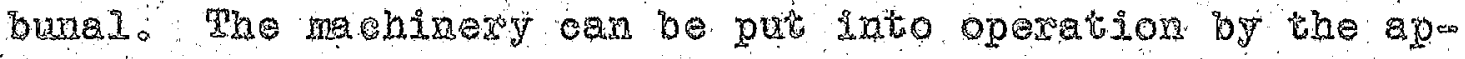
pointment or an ad hod body, is necossary, as soon as the nead ros it axises.

Labors Welrae: Thexe aro no speeialized ageneies controlled by the workmenthemselves. Some of the mployers have their own adeies ror the purpose. The rajiways have labor welfare inspectors who are required to ascertain the grievances of reilway workmen and to get then redressed. The ordnane depots, the ste mines, gat hedauarons,

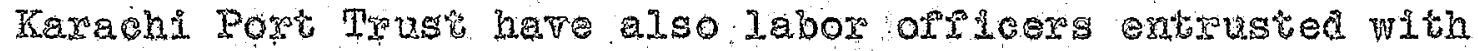
the work or labor welrape.

The Pakstan Copernent has established a Directorate

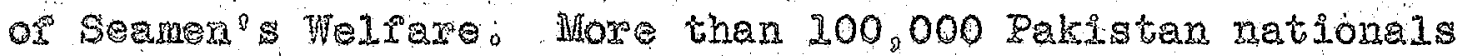
2re working seamen。 The Directorte is expected to direct; control, supetrise, ano coorainato semen ${ }^{\circ}$ welrare work at Pakistan ports and of Rakistan's seamen at porelga ports. Seamen welfare opicers have been appointed at the poxts

1. The Second Yeap. po85.

2. Pakiscen, po 128 。 
or Karahi and chitbagong. The welrare ofsicas are exo pected to intris themselves in the health, regreation, a lub and hostel pailities for seand and in the provision of amenties both ahore and arlogt.

thile it cannot be denied that reys little has bean done tomare promoting the welpare or labor, it appears that a good beginning has bern made and in the course of time conditions of labox shoula improre.

\section{Oxganizations of Capital and Zabor}

Capital: Thex is not a simple oxganization which may De regarded as ruly representatre of opital for the whole or Pakstan Thero ar howeter ootain oxganzations such as the Ulusim Chamber of Comere, Chittagong: the Indian Herchants Association Karahi: the Buyers" and Shipperg"

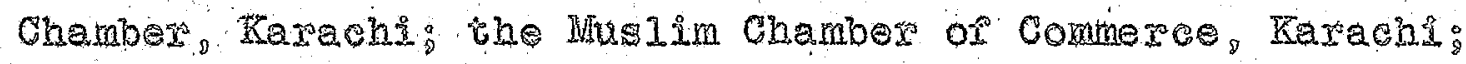

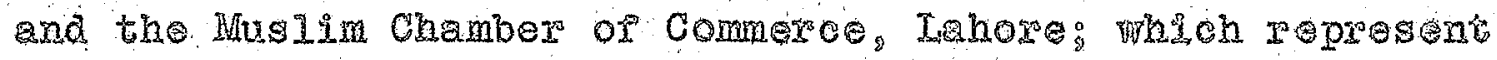
certain sectonal interests only. The goteriment has been nominating representatives of some of these oxganizations to represent capital in the various netional and international eonrexences.

Labos: Berore partition there were two important oro grnizetions in India, namely, the All India Trade Union Com gress and the Irdian Fodaration of Labor. After partition the 1a bor leaders, whose rield of actionty pall in Pakistan

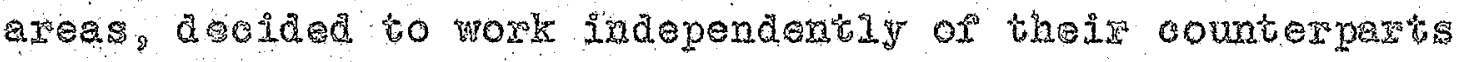
in Indi2. The unions in these areas which were previousiy 
arrilited to the AII Inda Trade Union Congress Pormed thomselves into the Eastexn Pakitan Trade Union Federation and Pakistan Trade Union Tederanion, Por Eastem and Western Pakistan, respectioly。

The zormer has 35 unions arfiliated to it, and cleims to here a membership of 48,000 . The waions in Nestexts. Pakiso tan, when were protously artiliated to the Indian Federa tion of Labor, formed thenselves into the Pakistan Federao tion of tabor. This has 21 unions artiliated to and claims to heve a membership of 31,000 .

No national orgenization which may be regaxded as representative of labor in the whole of Pakistan has as yet omerged. Such ax orgenizgion, however, is absolutely neceso sarty in the interests of the laboring classes, and it is hoped that one will come luto existenee berore long.

\section{Labote Law}

Pakistan has inherited a labor code prom undivided India. she is a mernber of the International Iabox Organiza tion and has declased that as pree country she believes in social Justice and it will be her endearor not to lag bec hind ang of her deighbors in the marob of progress in the labor fieldo

The working or ractory and labor legislation is 
whumerized as rol1otis:

Fatory Geistation: Fatory Iogislation aims at the regulations corering conditions of rork. The present posic tion is regulated by the Factories Act of 1934. It was amended in 1946 when a 48 wour week was oncoxed. The Act applies to industrial undortakings using mechanical power and employing not less than 20 pexsons.

The rorking hours for children are tiad at pive pers day. Women and children are not allowed to work at wight. The provincial gorexnents are enpovered bo poseribe Gtandards or arificial humidicaton, protecting workers aganst excessive heat, and providing west sheltex in fao tories. There are provisions to onsure sareby os iactory structures:

Pagmont or Hages Act 1936. This Act applies to pero sons enployed in tactories and on railways. The mage periods must be fized, and no wa perlod is to ereed one month. In the case or pexsons whose serpices are texminated by the employer, theiz mages must be pald berore the expira fion of the second woxking day forn the date of discharge. Al payment of wages must be me on a working day in euro xent cosa or ouraney notes or both.

The Aer lats down details or deductions, rines, and

1. For detailed discussion, consult Hinistay of Eeoo gorde Arraiss, Investment Opportunities in Pakistar

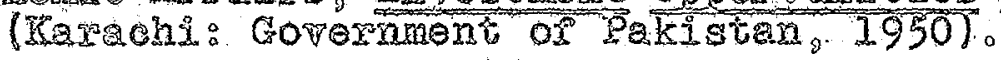


adtances, and makes a contract or agyeenent wherby an en ployed person relinquishes any right conered by this Act null and wosd.

Industria DLspuces Lepislation: The Industral Diso putes Aet of 194 is the only centrel legiglation on the investigation and settiement of industol disputas. It prohibits strikes in a publio utility sexpice (a) without the mployee giting notice to the employex or a strike within six weeks before striking; or (b) before the apoira. thon of the datos of strike specisied in any such notice as asoresaid, or (e) during the pendeney of any conciliation proceedings. Simlaxly, no emplogex engaged in public utility sexice can loek out its workmers (a) without giving ther poper notice within six meeks berore locking out, or (b) during the pondeney of any conciliation proceedings. The Act proyde sox the ingestigation and settlement of Industrial disputes through the ageney of a couro of Eno quity or a Board or Conoiliation or an Industrial Tribunal. It also makes provisions for the establishment of works comitceas to promote measures por presering ansty and good selations, as between employers and their workmen. Concilio. ation orticers are appointed wader the Act ohatged with the duty of mediting in and promotixg the settiement or induso trial disputes.

Tyade Union Act, 1926: Under this Act, any seren or more members may aply for registration of their trade waton. The registrax is bound to register a union it it 
complies with the provisions of the law. It necessitates xegular constitution, a perodion andits the composition of the exective so that a marity may be morkexs In seo turn it exjoy immuxity from the conspiracy provisions of the Citil and Criminal taw in respect of any act ane in contemplation or tuxtherance or the aispute.

Workmen:s Compensation Act. 2923: The Act applies to Q11 wotkers in fatories, mines, railways, ports, and caro tain other speciried oceupations. It imposes an obligation on enplayers to pay compensation for actidents arising out and the the course or their employmext and resulting in deach ox total or partial disablement for a pexiod axceed ing: serba days. Corpensation is also payable ror some ocers pational diseases. The amount of compensation depends on the nature of the accident and the anount of ayerage monthly weges of the workez concerned。

The Hiaternity Bexerit Act: There re Hoternity Beno it Actis rox monem employ in factories. The qualisying period raxies tron fire to nine moaths. The maximum pextod ox benefit is two months.

The Erployers" Iiability Acs, 1938: This Act abroo gates to a considerable extent the desense of "assumed isk and common employment in suits for dameges pom injuries sus tained by workmen. 


\section{CHAPTES VII}

\section{TRAIISPORT AND CONRENIOATIONS}

Wrasport and commications play an important role in the econory or any country. The most obyious arfect of ino proved transpoxtation is to rake valable to a comminty the goods whioh or necessity must be produced alserhere. A commung without cheap transportaton mus be largely selio suricing. Gimatic conditions and avalable natural reo souros I Imit the goods which may be produced, and only those Droduets tron othex lands can be brought in which will stand high transportation costs. Cheap transportation permits othex goods to be brought in. so that those products may beo come as commontace as the artieles produced at home.

Transport and communications are much more vital than usual in the case of Pakisian because the two Pakstan zones are not goographically contguous. Tastern Rakigtan is separated by more than $I_{0} 000$ miles from wastexn Pakistan。 The sea provides the ondy indepondent means of commication betwen the cro zones, and hence phipping, combined with

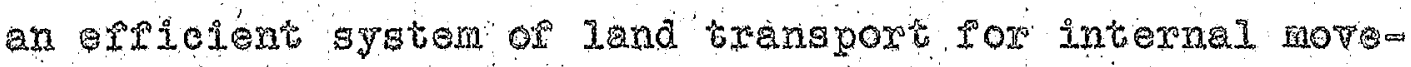
nexts, wl play an important part In coordinating their actrities in the conome sphere and in supplementing each other s requirements. 
As stated berox, pelstan 1 s a a groultural country producing in abundance raw meterals such as jute. cotbon, hides, skins, and the like which are exported to other covntries, and this means heavy polume of trapio tow irds the ports. On the other hand, glnce Pakistan is industrib ally underodereloped, lazge quantities of manufactured goods are requixed to be imported and dstributed in the hintero land. Additional strain is put on the tronsport system by the morement of coal which, due to its shortage in the eovam try, has to be impored from a broad in large quantities.

Besides, rood must be hoved roon the surplus areas ot Rakistan to its depicit areas and also rox exportabroa The present industriation schemes of the country necese sitate the morement of mahinexy and materials: on a large scale. Abore 21 , the derense requirerents or the country necosptate an epicient system of eomranicaton to ensure a high degree or mobility of her armed porees and quiek moveo ment of supplies.

\section{Railway Transport}

The railways are the main a raties of transport. The total leagth of reilwoys in Pakistan is 6,982 miles which Is dVIded into two main systems, namely, the Noth Westera Raiway in Westem Pakistan and the Hastern Bengal Railway in Eastern Pakistan. The present position of xoute length

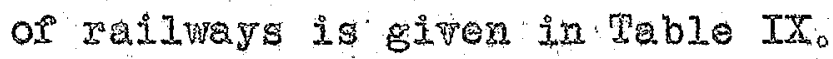


TABLITIX

CLASSIETCATION OF RAIIWAY BTLEAGE ${ }^{I}$

\begin{tabular}{|c|c|c|c|c|}
\hline Railuas & $\begin{array}{l}\text { Bxond } \\
\text { setge' }\end{array}$ & $\begin{array}{l}\text { Metre } \\
\text { stage }\end{array}$ & $\begin{array}{l}\text { Naxtrow } \\
\text { gestge }\end{array}$ & $\begin{array}{l}\text { Total } \\
\text { mas Ies }\end{array}$ \\
\hline Noxth Hestern Railway & 4.562 & 319 & 482 & 5.363 \\
\hline Rast Bengel RaIIway & 898 & 1,201 & 19 & 1,619 \\
\hline Total & 5,060 & 1,420 & 501 & 6,982 \\
\hline
\end{tabular}

West Pakigtan is served by the North Hestern Railway which connects Earachi, the foderal eapital and the most in portant port of West Pakistan, with ald the important toms of the sogion. The main tounk of this railway runs from Karachi to Iahore and thence to Peshatrax. The Khyber Pass is contrecte by rail to Reshawar, and thus transport raoilities are prorided to the renotest northrest cornex or the country on Axghanistan borden Anothex important bxanoh conco nects the federal coltal to quetta and Chaman and rus to Zabidar in Iron terroftory。

A netwoxt of branches, which are most intenge in Punja,

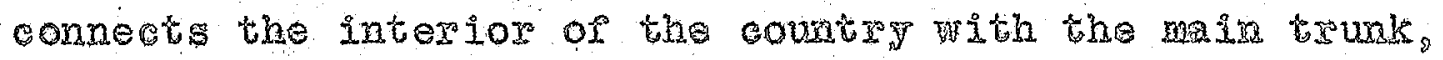
thus providing quick and convenient transport throughout the countyo, The important ral Iins rith India is that between

1. IMnisty of Eeonomic Arrairs, Basie Facts about

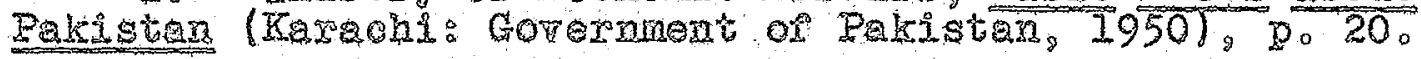


Lahore and Amstosar but sine partition the tratrie on this line, especially that of pessengers, has been restricter Qd.

Hast Pakistan is sexted by the Hast Bengal Railway Which has a route mileage of about 1,620 miles.. This railo way serves at area smeller than that serped by the Horth Nesterin Rilway but it has much greater density of popula tono The ralways of Rakittan a state entororise and so their preight pate poitcy is based on the considerations or broad poliey of providing racilities for industral and commereid development of the cotrtyy. Concessiond reight rates, prioxities, quick transport for perishable and frao gile commodities, and othex pritileges are orpered by the Pakistan raldrays

Both hese railwags had to tae aumerous problems and pass through many tieissivudes sineo partiton, and how they have progressed during the part three years is story mell worth xecpitulation.

Wornout Condition of Stock: The wornoout condition or roling stock was Pakistan's inheritance at the time or paro tition。 During Wora War II the railways in the two zones of Pakistan we subjected to very heary wear and tear. The government of the day found it inoossible, owing to the strain put upon its resources by the conditions prevailing during matrime, to obtalm adequte natarals to eary out

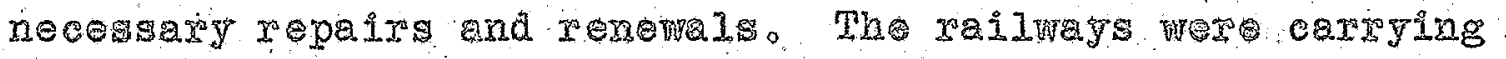
lasge rumbers of troops and supplies: and since the 
production mechinery in other combres which could have suppiled the decessary stores was geared to wartime produc tion, it was found impossible to teplace momoout stock。 Trigines and rolling stook which had reached the limit of its age pere prossed into service, while tho pormath way was subject to very heavy trapico Deteriopation was paro ticularig serere on the Hastern Bengal Rallway during the Burma operations where laxge numbers of troops and tast quantities of wax matezials and equipment were moved by xo. 1 .

Coal Shorbage: the local production of eod is excedo Ingly small and is insuitable por locomotite puxposes. India is wable to supply the rull requirements, consequento Iy arrangements have been made to import coal trom America and the United Kingdom. To reduce the consumption and de pendence on coal, some of the coaloburning locomotives have been convexted to oil piging

Inprovement in tyain Sexviees: Neretheless, in spite of all the diffoulties mentioned above, the trains kept rum ning. The North Western Ralway me a remerkabe recorery. In Hareh, 1948 ondy 74 passenger trains were wuning deily but by Haxch, 1949 the number bed yen to 191 por day. on the Tast Benga RaIway also there has been oonsderable agmentation in train servises.

- Taking both the Pakistan rallwys, the aumber of passeno gex miles increased rrom $2,215,502,629$ in 1948 (Apri1 to 
october to 3,075.252, 848 in the corresponding period aro ing 1949。

Movement of Coods: The arepage numbex or broad arange Wagons loaded daly during the period August 15, 1947 to March 31,2948 on the Noxth Wostexen Railway was only 886 , Whereas for the year 194849 this igure rose to $l_{2} 5650$ The number ruther increased Prom 1,565 in 194849 to 1,968 in 1949050. The netor miles carried also Inereased from about 170 milion in 1948049 to 177 mingon in 1949050 。 There was a gimilar proport sonate improvement on the Bast Bengal Railway. The statisties por this line are not avalo availabe.

\section{Roads}

While the rallways bear the major portion of the buro den of long alstane transport, the roads play their part in providing comparatioly short distance transport facilsy and in by 3 ging countryste nearet to more impoxtant comero cial towns:

Road transpoxt plags at inportant role in the economy or Rakistan, partly because railway transport is inadequate and party because it is through the network of roads that the rallways can be connected wh thural axeas. Road

1. Three Years of Pakistan (Kaxahi: Pakistan Pubilca tions: $1950 /, \mathrm{p}, 83$.

2. Los. cit. 
transport, which supplements the reliway transport, is thexerore essentid for the economid development of the cowtry and por the commerelizaton or agriculture. Agrio culture is the bate industry or the county, and so agxis eutural products axe the prineipal artoles or export nexo chandso. The rollwas cannot link erery rilago, and so a texy iaportant racitity of transport is protided by the roado

Roads may be classifiod as national highwy. proo

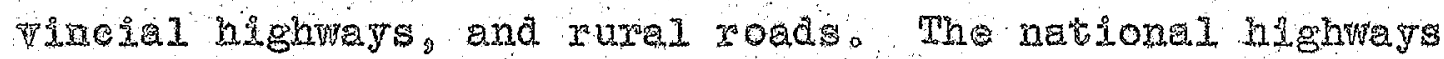
are of national impotwance and comect one pat ox the coun try wh anothex。 The provineial highways are the mein aro texies of road commuleation and connect important places or the protines with one another: they axe maintained by the prominces. Rural noads are or $1002 \mathrm{l}$ importance and serve the needs of tural areas and genexaly as peedexs to the na tional and provineial highways

The present postion about the miteage of the various types of roads in Pakistan is show in Table $X_{0}$

The aetional highways of Paklatan were subject to Very heary trafide on aceout of the movenent of thoops and supo plies during the wax. Arter partion these roads, especially in Western Pakitan were subjegted to further strin owing to the novernot of millions of refuges who ware conpelled 60 use prinitive rorms or transporto. As a result of this. the nationei highw have surrered greatig in nespect of their surtao condition. 
TABLE X

ROAD IULTEAGE IN PAKTSTAN

\begin{tabular}{|c|c|c|c|c|}
\hline Drotince & $\begin{array}{c}\text { Suposiog } \\
\text { ourado } \\
\text { roads }\end{array}$ & $\begin{array}{l}\text { Metal led } \\
\text { yoad }\end{array}$ & $\begin{array}{l}\text { Unmés } \\
\text { alled } \\
\text { roads }\end{array}$ & Totas \\
\hline Pasjab & 2,694 & 410 & 12,883 & 25,987 \\
\hline $\begin{array}{l}\text { North tes Tront } \\
\text { Propinos }\end{array}$ & 1,203 & 120 & 1,899 & 3,122 \\
\hline Sind & 597 & 160 & 12,648 & $12,4,05$ \\
\hline Beluohistan & 586 & 637 & $3.4,53$ & 4.676 \\
\hline Est Palcasta & 594 & 1,028 & 20.972 & 21,794 \\
\hline Rotal Pakistan & 5.574 & 2,355 & 50,055 & 57,984 \\
\hline
\end{tabular}

The existing road system is altogethere inadequate cono sidering the sequirements or the country. There are large parts of the countey wich are practically inaccessible bes cause they axe not connected with the rest of the country roads ors by railways.

Dreught animals are the mein source of transportation In the rural axea a cart driten by bullocks or camels is genexily used ror the purpose. The number of motor vehieles on the road in Pakistan is insignificant, as wil be seen som the roliowing table.

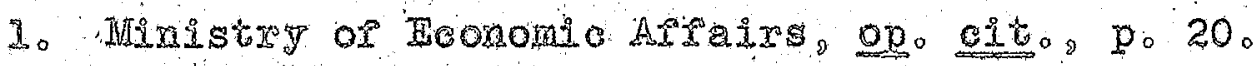




\section{TABES XI}

WUWBER OH HOROR TWHTCLES OH ROADS

(As of December 31, 1949)

\begin{tabular}{|c|c|c|c|c|c|c|}
\hline $\begin{array}{l}\text { Psorince } \\
\text { or state }\end{array}$ & $\begin{array}{l}\text { Private } \\
\text { earg }\end{array}$ & $\begin{array}{l}\text { Motor } \\
\text { cycies }\end{array}$ & $\begin{array}{l}\text { Taxio } \\
\text { cabs }\end{array}$ & Buses & $\begin{array}{c}\text { Loxples } \\
\text { and } \\
\text { Tans }\end{array}$ & Total \\
\hline Khairpur (state) & 45 & 12 & 8 & 30 & 35 & 130 \\
\hline Pusjab & 6,335 & 2,821 & 172 & 1,447 & 1,075 & 10,850 \\
\hline $\begin{array}{c}\text { North West Frono } \\
\text { tien enowinee }\end{array}$ & 1,520 & $\$ 81$ & 300 & 816 & 1.305 & 4,122 \\
\hline Past Bengal & 1,742 & 140 & 623 & 2,803 & 2,207 & $6,52 \%$ \\
\hline Bharalpus /state & 218 & 20 & $\Leftrightarrow$ & 64 & 205 & 4.07 \\
\hline sind & 5,297 & 896 & 222 & 326 & 852 & 7,593 \\
\hline Baluchlstai & 989 & 263 & 32 & 127 & 321 & 1.702 \\
\hline Totad & 26,246 & 3,242 & 1,357 & 4,623 & 5.970 & 31,328 \\
\hline
\end{tabular}

\section{Pors}

Suitable port reilities are important for the c00 zomic and industial devalopment of any countyo But tho geography or Pakistan, the two pats or which axe unconc nected by Iand makes existence of wellodereloped ports doubly inportant por this country. West Pakistan is pore tuna in possessing tho port of Karachi with adequate $\mathrm{reo}$ cilities to met all the immedate copeserable requirsments.

1. Three Years of Pakistan po 89. 
The rolume or tratile th thls port has bean steadily on the increase, as will be seen from the following figuras.

\section{TABIS XII.}

TUPORTS AND TXPORTS AT THE KARACHI PORT2

\begin{tabular}{|c|c|c|c|}
\hline Ye2s & $\begin{array}{r}\text { Imporos } \\
12 n \\
\end{array}$ & $\begin{array}{c}\text { Exports } \\
\text { 000\%s 01 tons) }\end{array}$ & Pota 1 \\
\hline 194704.8 & 1,156 & 1,028 & $2,1 \hat{8}$ \\
\hline $2948-49^{\circ}$ & 1,603 & 940 & 2,543 \\
\hline $1949-50$ & 1.908 & 924 & 2,832 \\
\hline
\end{tabular}

Chetragong Port: Fast Pakistan in the past was on tirely dependent upon Calcutta (Indiar port) and came into extstence without possessing adequate port racilities. The port of Chittagong has assumed great Importance since the birth of Pakistan. The full potentialities of this port wero allowed to remain dormant in the interests of calcutta, Full development or this port is now atcers of rital us geney fox the economic life or Hast Rakistan.

To reet the situation, the government of Pakistan quichy drew up a shototexm plan and stated to inplement

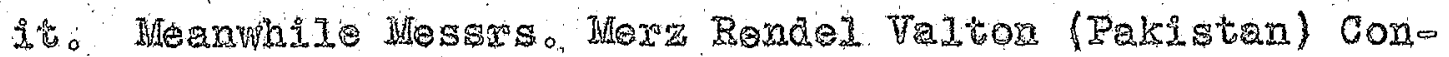

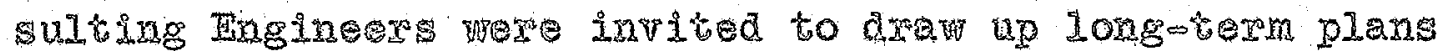
por the deralopment of the port. fhis rim is a combination

Io Three Yeaps of Patistan, go 89. 
of three welloknown engineexing sirms, one of them being Swedish and two Britishol the shortoterm plan consisted of extending two ort ox sour existing jetties, extension and reconstuverion of oristing two sheds, addition of a soparate jetty。 The shortotern plan has increased the capacity of the port from $500_{2} 000$ to 750,000 tons.

The longoterm plen aran up by the constiting eno gineers, which has beon approved by the goternment, is as follows:

2. Constructon or sew jetties lincluding one passeno gex cumolift jatcy)

b. Construetion or corresponding transit sheds, "saing and mashalling yards

c. Lighterage jetties with shods and roilway sidings

d. Exovigion of equipment such as heargolift cranes. mobile twuoks, shunting loconotives, and so rowth

o. Roads, Ilghting powes, water, and other sexwees

P. Bifer training works, and

go Now orpices for the port and custom autbosities, and a housing state for the sture

With the complotion of this project, the port capacity w11 have increased to 3,000,000 tons.

The posability of inding an altemative port has also been reeiring attention. To relieve the burden on Chitha

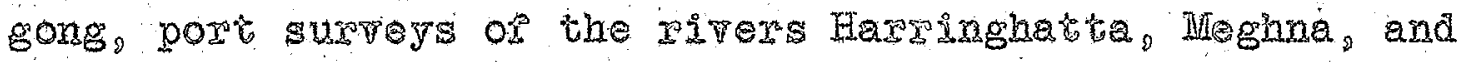

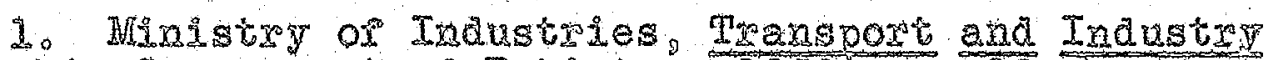

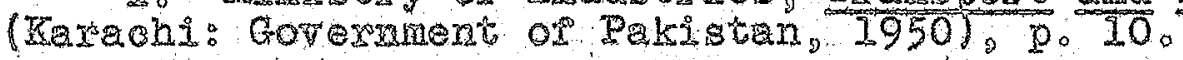




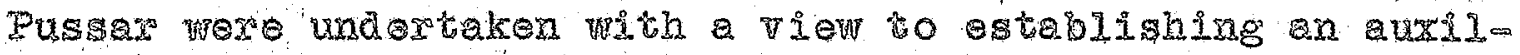
lary port. The suxveys have revealed the possibility or haring sheltered Iighterage and anchorage ror deep sea pessels. This seheme is in hand.

\section{Mater Mransport}

Internal materwass are another inportant means of transport, especially in East Pakistan, though so tar sull ad Tantage has not been taken of those natural facilities for chea transport. The rorex of tast Pakistan aro mostig served by coutry crart and barges which are extersirely used sor transporting jute, but most of these rivers are eminenty sulted sox heaviex ressels which can protide rastex oheaper and sares transport. A sotilia has been purchased by the Wast Bengal Railwy which will be used mainly to enlleet jute Pon the intexion of the eountry and bxing it to chittagong. the main port of East Rakistan.

The two Rakistan zones, which are not geographically contiguous, are compcted by sea. In addition to air, the only other independen means or transport between Fast and West Pakistan is by see along the Indian peninsula since partition, the ports of Karach and chlttagng, which were pormexiy only ports or call, have been declared also as ports or registry.

There aro two prineipal Pakistan shipping companies, namely, the Hohamadi steanship Company, and the East and west Steanship Compang. County etat provide not only short 
distace coastal transport pacijities, but a groat many or them corex Iong distances. For developing Pakitan shipo ping industry, many neasues are under consideration whioh Include the construeton of dry docks and increased por and storage Pacilities.

\section{Aix Transport}

Aix transport has assumed great importanes in modern times and, with the inpecrs of wertime inventions, it is still dereloping xapidly。 Fo Pakigtan it is paxticularly importent because of the Irmitations of swrece commilca tions and tho separation of the two partis of the cowntry by the streteh of and 1,000 miles mide. It has thererore. majox contrabuions to make in the lelds or nacional admino Istionton, naity and economy of the country.

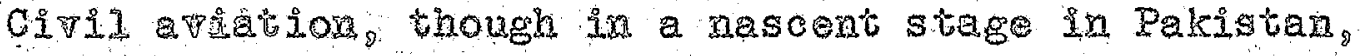
is attracing due atcenton as a means or quiek transport for bringing the faxmextending regions of the conntry closer. At the time of partition in 1947, Orient Arrwas was the only alrine registered in Pakistan "wich then operabed short service. This was evidenty not suifielent por the country need and soon a Icense nas issued Por. Pak Arruys. Both the alyogs have gince been extending the circle of their operation, and in addtion to internal lines they here been operating some serpices to neighboxing countries.

With the acepton or the Kaxehi aixport, there was at the time of patition a seroons shortage of the earodxade 
equipment in Pakigtan. Since then the position has ine proved. Current plans provide for the operational mening or the pollowing aerodromes to appropriate standard: Karach, tahore, Quetta, Hyderabad (Slad) and Ifutan in Westarn Pakistan; and Chittagong, Decoa, and Sylnet it Eastern Pakistan. In adalun, the air force aerodrones at Ravalpuidi and Reshawa are aralable to oivil airlines. Karachi a irport has beed fitted with fhe modern bigh intensity contact runways Ilghting. system. This is the only airport in the astern oountries having this type of night lighting equipment by means of which pilots axe able to land salely in bad weather. Besides, Karachi, being on the trunk ait routes of the world, bolas an extomely inportant posic tion. It commands all the importan routes to the middle and the Fas Mast.

Agroenents: Soon arter parition the government or Pakistan notitied its adherence to the conrention of Interne

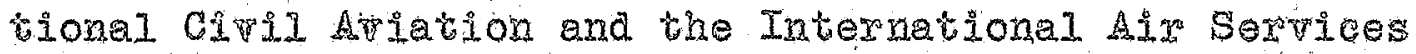
Transit Agreomento On December 5, 1947. Pakistan became a member of the Intexnational Civil Alation Organization which alns at foxldwide standaxdizaton of eivil ariation sarecy and operatonal standards and practices. Pakistan also beo ceme amber or the Commonwe Ith Alp Transport Conncil.

1. Pakistan (Eondon: thomas de la Rue and Coo, 1949), 222 . 
Whe United States, Netheriands, and France wete in Pormed in 1947 that the aito transpox agreoment negotiated between their gorexnments and the und ided government or India were acopted as binding on Pakistan. Futher agree ments have been conduded and signed since with sweder, Coyo Ion, India, Austyali, Norwa, the PhIIppines, the United Tingolom, and Denmark.

\section{Postal Servicos}

Ia matters or jatand postal sertice, extensipe pacio itries are artoxded by the Post and Telegraph Department of the government of Pakistan. Pakistan is a menber of the Intexnatonal Posta Union and has postal links with all the

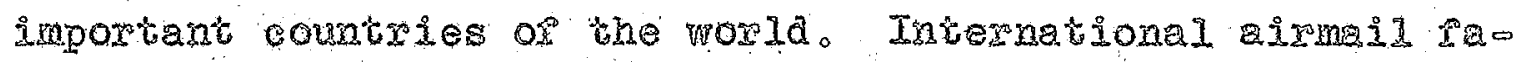
cilities are also provided, and internal aimeil service is arailable between jmportant toms and between Hast and West Pakistan。

\section{Lelecomminication}

Tuere are both internal and extonal connections which itak important town in the country ith eqch other and also proride connection with overseas countries. The total mides age of telegraph connections, both externel and internel, at the Inception of Pakistan was 200,000. The total Installed

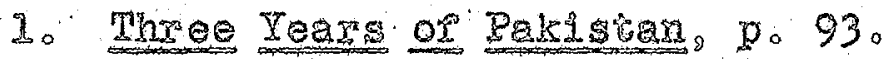


depelty of telephone exchanges in Pakistan is 15,000 Lines.

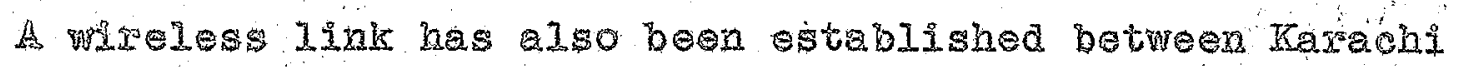
and Decer. Dakistan has a direct wroless link with London and also a cable linko Karach, and through Kaschi the whole country is connected with Nen Youk on direct wire less tolegraph areudo

Radio telephone felities with New York are available via London and Berne. Diroct radio telegraph circuits aro working with grgt and Iran, and direct rado telephone tiras with Iond on and Berne connect Pakistan wh the whole or the Europera continent. Irtension of these racilities fo south Amexioan comntrios has recenty been artarged。

I. Ministigy of Economic Ajraixg. Investment poportunio ties in Pakighas (Karachi: Goveranenc op Pakistan 1950$)_{2}$ $p_{0} 210$ 


\section{CHAPTER VIII}

CURRENCY AND BANTKUIC

\section{Cuxperers}

The partition plan was axnounced on Juse 3,1947 and August 15,294 we the date rized fox this plan to take a practical shape in the romation or two separate Dominions. India ard Pakistan, Since the entire work fon connection with paxtition had to be completed by the middle of August, it was considered untrise dit that time to force on immediate di yision of the monetaxy system. The security press of unditided India for the printing of the papere evrexsey was situeted in the territory of the Indian Union. Thus arter partition Bakistan was without a security press of her own. So she had to enter into temporary arrangements with the In dian Union with regard to hex eurrency:

These were embodied in the Pakistan fionetary System and Reserve Bank Order, 1947, of which the main 1 eatures in respect or Pakistan euryeney vere as rollows:

1. The Reserve Bank of India would continue to be the

\footnotetext{
1. The Second Yeax (Karachi: Pakistan Publieations,

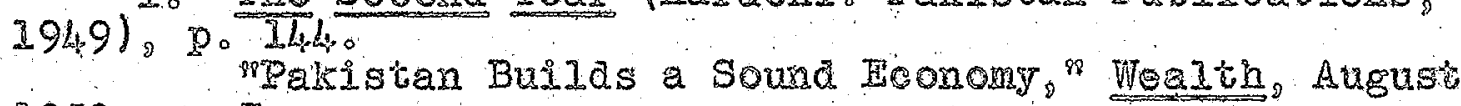
$1950,0.7 \%$
} 
sole notewssung authority in Pakistan till June 30,194 and Inda rotes mould continue to be legal tendor in Pakista tild theno The Resere Bank or India may issue aro

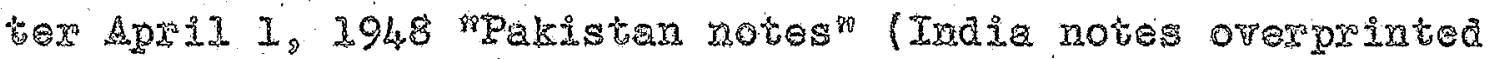
with the "Gowexnment of Pakistan". Artex June 30, 1948, howevet the Ragerve Bank or India would not issue ang notes tor Pakistan, and the goternent of Pakistan had to make its ow arrangenents ror issuing eurrency notes. 2. Soon arter Jun 30,1948 , assets of a value equal to the Paklstan notes would bo trangerred pom the Issue Depariment of the Reserve Bank of India to the gorenrant or Pakistan. The government or Pakistan wond acept Irdia notes at par until Jure 30,1949 and assess of the value equal to such "India potes outstanding in Pakistan would be

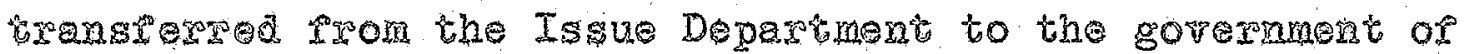
Pisistan。

3. As in the case or eurrency notes issued by the Rer sexte Bank of India, the rupe coins and subsidiany coins issued by the gorexnent of India would be legal tendes in Pakistan at least por one year from the introduction of the coxyesponding Pakistan coins. The Reserte Bank of India arter Maroh 31, 1948 would put into oiroulation Pakistan ooins as tax as possible. and use India coins only to supo plenent them when they are in short supply. Apter June 30, 1948 the governinent of Patsigan would be responsible por iso suing coins.

But axhapy owats that followed the partiton compolled 
Pakistan to rise this antangemeat and to establish it own montary authority e ariex。 It was subsequentIy agreed that the Rescre Bank of India woula cease to operate in Pakstan aster Jume 30,1948 , and that up to that date it would also continue to nonge the public debt and exchenge control opo etrations on behals of Pakistan. It aceordanee with these xeriged aragements, the State Ban or Pakistan mas estabo Iished and it took over the central banking and currency authoxity of Rakistan from JuIy 1 ; 1948.

Idada notes, that is the bank notes of the Reserpe Bank of India continued to be issued in Pakistan wnil Mareh 31, 1948, Or Aprid 1 , 19k8, the issue of Pakistin Insceibed notesoothat is. India notes inscribed with the word "Government or Paksistan in English and Urduowas commenced。 As Prom Oetober 1, 1948 the State Bank of Pakis tan begen issuing Pakistan notes of the denomination or

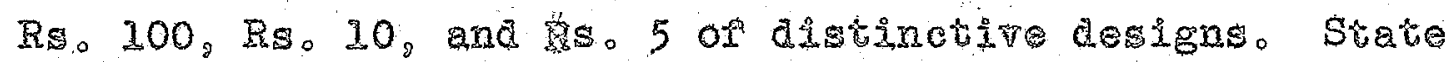
Bark of gakistan Rs. 2 notos and gorernment of Pakistan oneo

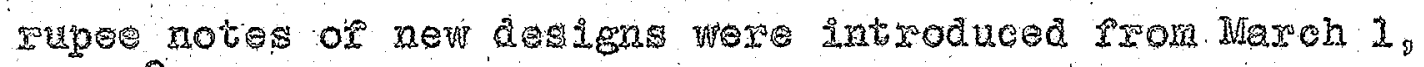
$1949^{\circ}$

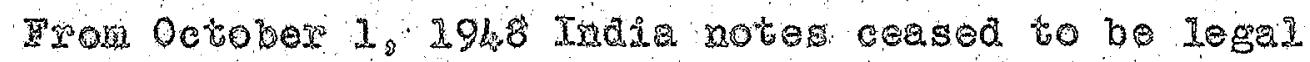

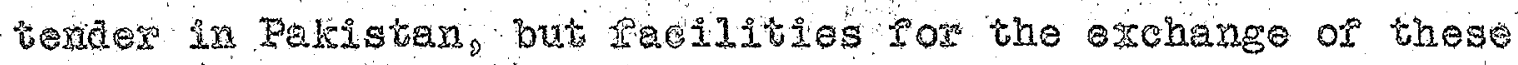

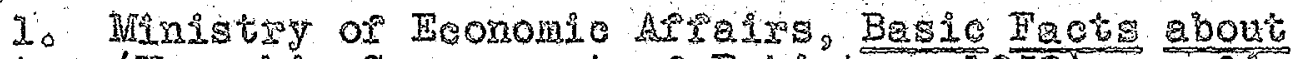

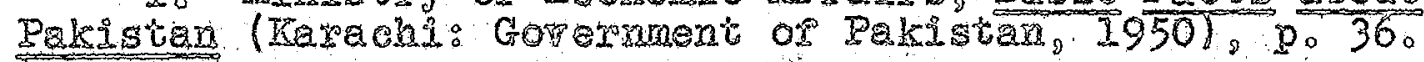
2. IDId $\therefore$ D. 37 . 
notes, except onerpoe notes, were propiad up to juno $30_{2}$ 1949. The government of Pakistan was under no obligation to exchange the one-xupe notes atter septembex $30,1948$. When they ceased to be legal texder. However. to awoid hadship to the holdex in Pakigtan, these notes were ex changed toith Pakistan notes up to Jaruary 31, 1949.

The State Bank of Pakd stan possesses the sole fight to issue bank notes in Pakistan. Ifs note issue would be pully covered assets consating or gold coln. gold bullion. silver bulison, gtering securities, appoved forelgn exo change supe colm and rerpee securities. of the total anown of the assets or the Issue Departane of the Bank. not less than 30 per cent shall consist ox gold coln, gold bulion, sterling segurtics, and appored poreign exchango The renandex of the assets ghall be held in rapee colns rupee securities, appored bills of exchange, and promissory notes:

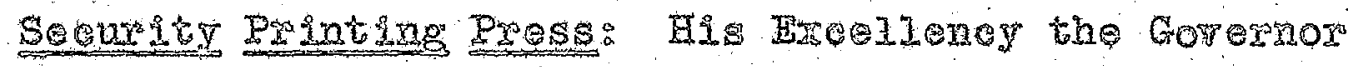
General of Paktigar ladd the foundaton stone or the secuxity Fass at Karahi on Warch $11.19490^{3}$. This was the rist stop to inplement an agrement reached between the gorernent or Pakistan and Hessis. Thonas de la Ruo and Company. Lta. London, rop the setting up of a security printing corporaton

1. Ihe Second Xeas, 9.45

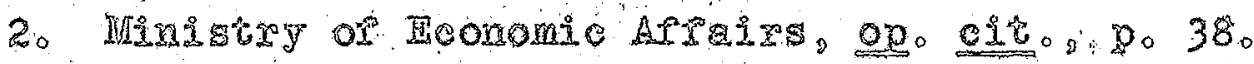

3. The Second Yeas, ppo 49-520 


\section{TABIS XIII}

PAKISTEN NOTHS

(In $000^{\circ}$ of Ispees)

\begin{tabular}{|c|c|c|c|}
\hline Month & $\begin{array}{r}\text { Hores } \\
2 \text { SSued }\end{array}$ & 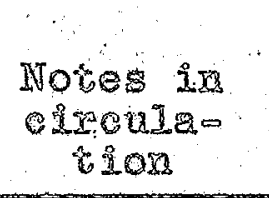 & $\begin{array}{l}\text { Notes hela in } \\
\text { Banking Departic } \\
\text { mert or the } \\
\text { State Bank }\end{array}$ \\
\hline July, 1948 & 759,857 & 700,557 & 59,300 \\
\hline Oetobers 1948 & $\$ .463 .460$ & $1,397,600$ & 65,860 \\
\hline To.rovery, 7949 & $1,817.555$ & $1,799,280$ & 38,275 \\
\hline Aproil, 1949 & $1,819,206$ & $1,722,915$ & 96,291 \\
\hline$J u l y, 1949$ & $1,700,551$ & $1,659,556$ & 60,995 \\
\hline October, 1949 & $1,680,29 \pi$ & $1,633,007$ & 47,184 \\
\hline Taxuxy 1950 & $4.789,546$ & $x_{2} 74,5,563$ & 43,983 \\
\hline Aprid, 1950 & $1,843,67 \%$ & $1,780,597$ & 63,080 \\
\hline
\end{tabular}

Whe figures ip to June, 2949 being exelusite of India notes do not represert the total notes in eireulation in Pariso tan. India notes to the value of about 1,750 milion wex witharam r rom eisenlation by the end of June, 1949. $100=\mathrm{R}, 332 \mathrm{~s} / 2$

whieh 11 print security documents such as currency notes posta and revenue staps. The Compang has undetaken to provide the neoesary machinery and equipment cor intaglio princing of the latest design. Techical artangenents to be made mill asure that the products of the lactory a equal in beauty, morkmashig, and security to those of ang other ractory in the morld. 
The technical exports required will initially be made \&vilable by the Company, but it wil take imnediate steps to train nationels or Pakistan rox occupyng positions or responsibility in the coporation. The chairman of the corm poration will be appointed by the gorexnont.

Currener Policy: The elxreney poliey or the goreras ment is not lixked with either gold or silrer. It has only one object and that i to ensure ordexiy trade, both Internal and external, and stable conditions of employment at a high letel in the courty。 Whthin the county the state Bank or Pakitan is resporsiblo sox onsuring that sound credit conditions aro neintained. Production and employnent axe ancouxaged ox discouraged by the oxedi policie adopted by the banks, and it is in this rield that a central bank has to play lts most important role.

The baxk has no spectaculat achievements to describ and tecono. It is yet an infant strugging to take its place in the scheme of life. Thateret has been achieved so rax is in no why 11 , but mat remains to be achieved is still bigo. The grownd, howeter, has been prepared; the condarion has been laid: some strueture has bean built: Sill mueh remans to be done.

Pakistan's Dedsion not to Devalue: In Septenber, 1949 po $54 \%$

1. Pakistan (tondon: Thomas de la Rue and Co. 1949). 
the Eaglish pound was deralued rrom a rate or toos United States dolla to 2080 dollers. Iraja deralued its rope co a similar extent. The old exchange rate wes 13.2 rupees to the English pound and 3.2 pupess to the United States dollar. But Pakistan, taking her economic conditions as a Whole in view, did not deralue her curreney. Thus, whereas

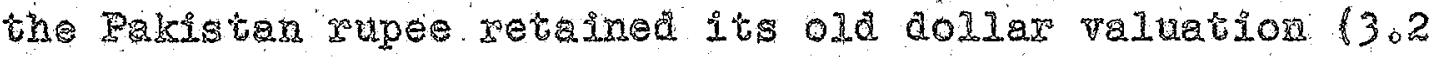
rupees to the dollar ${ }_{2}$ its new exchange rate mas 9.26 Pakistan rupees to the pound las against 13.2 wupees to the English pound at the old exchonge patel.

Pakistan ${ }^{\mathrm{s}}$ docision not to devalue was explained in a broadcast by the governox of the State Banto

Pakssan is a predominantiy agrieultural councry, and is in need or industrializabion. Deraluation would have placed the hardacurrency axea bayond its reach, which is a cheap and soady soures of eapital goods.

Pakigtan being an importer or consumer goods, it was antio poted that the new pate of exchange would redice the cost or Importad goods (both consumer goods and capital goods! and consequenty bring about $\mathrm{f} z 11$ in the cost ox 1 iting of the peopleo

Toselgn Hxchange Regulations: The goverament or Pakistan has libexally provided all racilities for obtaining

1. Broadeast Prom Kerachi on September 22, 1949. Quoted in Richard Symonds. The Hfaking of Pakistan (London: Tahes and Tabex, 1949), po T14.

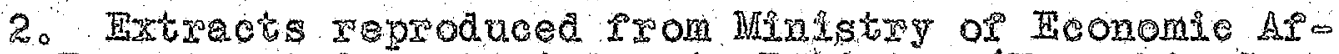

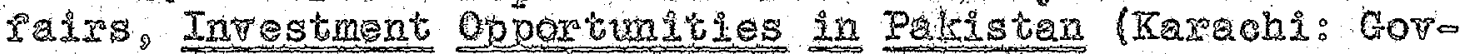
ment of Pakistan $1 9 5 0 \longdiv { 8 0 6 3 }$ 
Sorelgn exehang. Undex the FoxeIgn Exchange Regulation Act, 1947 , all dealings jn roreign exchange are subject to zegulation and they can be caspied out through barks authoro

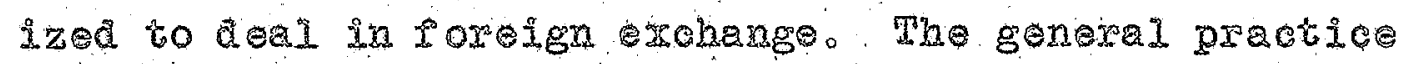
wader the present setoup of exchange control is to supply roreign curreney or rupes to now pesidents pernithed ror appored current transactons

As Iald down in the statement of industrial policy, the govariment or Pakistan provides facilities por the remito tance or profits to countries rom which capital is dram. For agn nationels who are temporarily resident in Pakistan are pexmited to make remittances to thoir ow countries por payment or insurance premiums or other expenses, support or Parilies, ducetion of children, and the like.

Payments in respect or imports rom outside Pakistan are reely allowed, provided the goods have been imported arter obtaining an import license wherever necessay.

\section{Banlings}

The Hones Haxet: The noney maxet in Pakistan areas beiore partitior consisted of the indigenous money lendexs and bankexs, the caperative banks, other joint stook banks run on modern isnes, and the Reserve Bank of India.

As result of the exchange of population, the money market of Fakjstan was completely aisloceted The indigen onous money lenders and bankexs, who were mosty non Muslims, lent the country en hasse. They supplied crodit 
Pacilites to the people ia rural areas. They charged exorbitant retes, yet they provided a userul service. Their exodus lert a complete roid in the credit structure of the countrygido.

The state or the banks run on modexn lines also con sisted mostiy of non-liuslims, whose sudden deperture from Peistan xesulted more or less in the complete breakdow of the banking gertices for some time。

The partition thus resulted in indespread chaos in the banking system of the country。 Sereral benks which operatiag in Pakistan berore partion either elosed their business or curtailed it considerably. In preopartition days thaxe were 22 soheduled banks with 229 bronches in Punjab and North West Frontier Province. There weto only two banks functioning with a total of setren branches in all 1 artas partitiono

The Central Bank: It was wer these circumstruces that the state Bank of Pakistan, which is a central bonk, was established on July 1 . 1948. Unlike some of the ather central banks, howerers, the state Bank is not controlled by

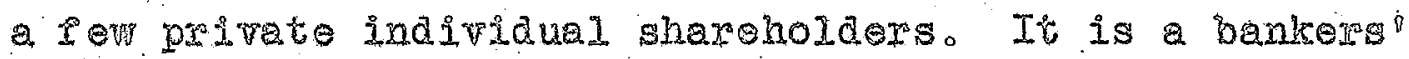
bane, baker to the central and propinodal govemments, and also a shareholdexs' bank. Itreg scheduled bank has to maintain a balane with the state Bank, the amount of which

1. Ministry of Economic Aptairs, Basic Pacts about Pekistan, po. 340 
shall not at the close or business on any day be less than 5 per cent or their demend liabilities and 2 per cent or their time liabilities.

The State Bank controls and regulates the currenoy. credit, and foreign exchange or Pakistan. It discounts paper and enters into the market pop purchase and salo of securities. Howerex, it does not engage in trade nor influm ence directy any or the commercial and industrial undertak Ings. The bank also manages the Clearing Houses at Karachi, Dacea, and tabore on behals of the clearing bankers.

Mention should also be made of tho training scheme Iaunched by the State Bank with a view to meeting the shoro tage of trained personel which the banking organization ielt immeditely arter partition as a result of largeoscale mio gration to India of non Mfuslims who dominated the whole bank Ing system To overoome the acute shortage of technical pero sonnel, special axrangements have been made ror the training or Pakistan nationels in banking in Pakistan and abroad with the leading banks.

Expansion in Baiking System: The position of the banko ing system had materially improved and the number of of ices of scheduled banks had increased to 225 at the end of JuIy. 1949. The improvement was mainly on account of the estabo Iishment of the State Bark, and the stable and sound

1. Ministry or Bconomic Arrairs, Basie Facts about Pakiston, po 35o 
rinazed position of the country.

The ofrices of scheduled banks in trandous provinces at the end of Aptal, 1950:ate shown in the following table.

\section{TABI型 XIV}

DISTRIBUTION ON OFTIOTS OF SCHEDULDD BAINKS

Provinee

Past Pakistar

Purjab

$\operatorname{Kax} 2 \mathrm{chi}$

sind

North Nest Frontien Province

Baluebistaro

Bhengarow

Total
- Nrumber or

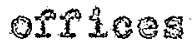

55

25

12

9

5

5

193

Industidal Hiance Corporation: To provide medium and

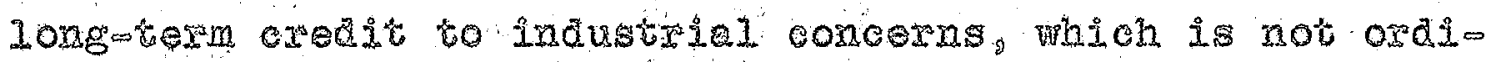
nasily arsilable from comerial banks, the government has set up an Industral finance Corporatson wh an a uhorized share capital or Rs. 30 million of which 51 pex cent has been subseribed by the gorernment.

1. These Yoars of Palistan (Kardehi: Gorernment or Paksistan, T950) 100 3Is32。 
Rolugee Rehabilitation Finance Cosporation: Some geven milition rexuges aprooted trom houses in India came to Rakistan immediately attex partition of the subcontinento To provide eredit to enable then to take to some vocation and thus earn their liting, the centrel goremmont estab Iished Fakistan Reruge Rehabilitation Inance Corporation. This Corpotation is inanced entixely by the State.

Natonel Bent of Pakistan: As the existing banking cacilites we not adoqute cor the requimements of Pakis tan. It was considered necessary to establish a gtrong como marcial bank to ssist in the ocononie, commexiel, and in dustrial development of the comby The National Bants of Rakistan ordinance, 1949, promides cor the inmedimte estabo Iishment of a goverimentosponsored commerelal bank to be called The National Bank of Pakistan.

The head of ice of the bank is located at Karachi, and the business of the bank is managed by a central Board of Directors wh three local boards at Lahore, Karachi, and Dacea. It has an ambitious programe or opening out neto work of branches is the interdot of the country in both ming of Pakistan.

Cooperative Banks:. The cooperative banks, which are semi-goremant institutions. me matained meing tox the

1. Pakistan Stabilizes her Baking Setomp Nealth, August $1950,00.18 \circ 19$.

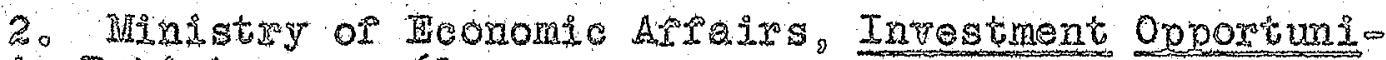
ties in Pakstan, po 61 . 
provision of exedit to the agxioultarists. As the banks are goverament controlled and not dependent so muck on prit Fate enterpise as the othey joint stock banks, the gorerno ment tried to rix up the gap as far as possiblo by increas ing the riela or actirity of the cooperative banks. 


\section{CHAPTER IX \\ INTERNATIONAT TRADE}

\section{exports}

The exports of Pakistan meinly consist of raw jute. cotton, wool, hides and skins, and lood grains, The see borne exports including resexports during $1948 \mathrm{ckg}$ and 19490 50 were palued at Rs, 91.7 million and Rs。84.8 milion. 1

respectivelyo These figures do not include expotts to India by land coutes, which are considerable:

Jute: This is the principal expoxt of Pakistan. Ano nusl average production or jute is about six million bales ot 400 gounds each. ${ }^{3}$ But there is not a siagle jute nill in the country, so the entire exop is exported. By far the greater part of it is sent to India, and the belance to the rest of the morta.

Pakistan ${ }^{B}$ ability to export jute directiy to countries

1. $100=3321 / 2$

2. Mrinisty of Heonomic APrirs. Basic Facts about

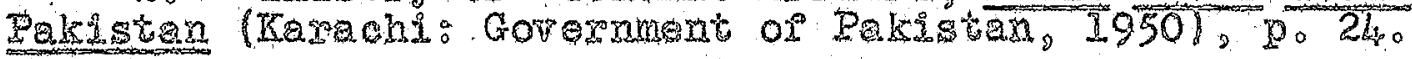

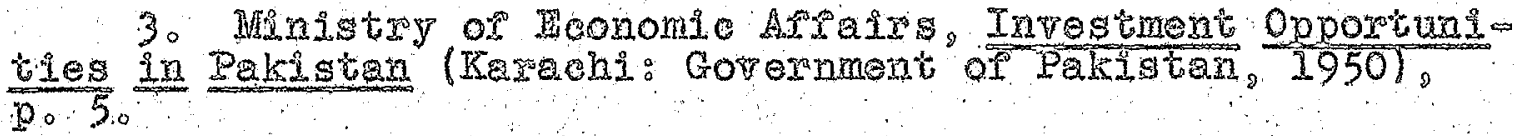


othex thas India is Iimited by two pactors, amely, the balo ing eapactit or the jute presses in Rakistan, mich is not Wory large: and the handing capaity of the Eastern Pakise tan port of chitcagong, which has jet to be developed This explaing why the bulk of Pakistan's jute production is ex poxted to India the total raIue or exports of jute during

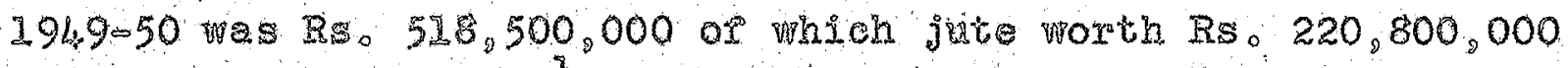
mes exported to India.

Cotton: Nert to jute, cotton is the most important como modity eponted rom Pakistan. Its production is conined manty to Western Rakistan. The annual production is about one and a balt milion bales of 400 pound s each the greato ex part of wich consists or long staple American rarieties parying in length pon $7 / 8$ to $27 / 32$ inch. As there are very sem cotton texile mils in pakistan, the consumption of coto ton in the country is rexy small. The butk of the erop is arailable por exporto

Palistan's exports of cotton during the year $1949-59$ totalled 800,363 bales which in terms of value anounted to Ro 355,000,000, The noin cuscomers mere France, Japan, the United Kingan, Gerway, Poland, and Italy.

1. Three Years of Pakigtan Karachi: Pakigtan Publica toons, $1950 \% ?$

2. Innisty of Beonomic Afrairs, Investment Oppoxtunites in Rakistan, $\mathrm{g}$. 5

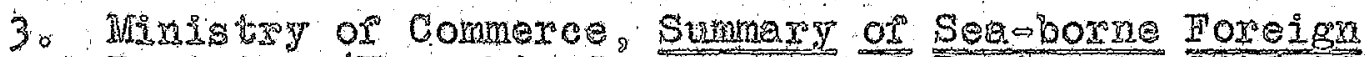

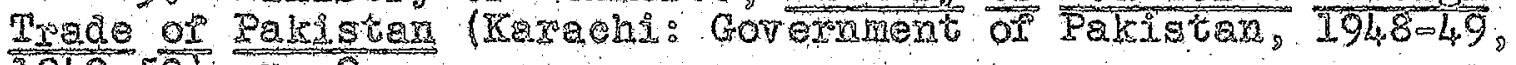
$19490500_{0} 90$ 
Wooja Pakistan produces 24 milion pounds of ratip Wool. As the 10cal consumption Is nogigible, the entire quentiby is exported ox raw wool shipped to ororseas counc tries during the year 1949050 the total amounted to Rs. $31,600,002^{2}$. The Urited Isngdon and the United states were thi principal customexs. The United States, which was Pakism ban's biggest customex or waw wool in $1948 \times 49112.7$ milion pounds tedued Its ont-take to 9.2 million pounds. The United Kingdom bedme Pakistan?s biggest buger, caking about 12.6 milion pounds as egainst 8 .4 million pounds in the preeding gear. Pakistan's ather oustomers or raw wool were Canada, Italy, BeIgin, Gemany, and Japan.

Tea Tea is an important artiele or export ryor East Pakistano Pakistaris annal output or ter has been estimeted at 45 miliox pounds About 70 per cent of this quano tity is exported evergr yeax. The total shipment of tea was 53 ralizon pound ralued at Rs。 $79,300,000$ in 1947048 . It aecline to 26.5 milion pounds in $194849:$ tho arentity exported Inoxeased by seven million pounds and sood et 33.3 miIson pounds valued Ro $49,200,000$

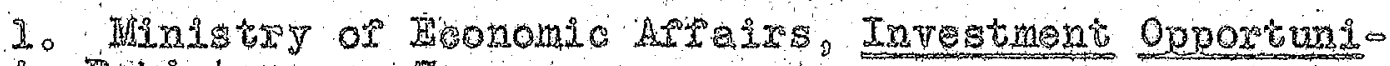
tise In Eakigtan, p. 7 .

2. Loo. 16

3. Thee Year of Pakistan go 38. 
Pakistan ${ }^{\mathrm{S}}$ tea industry faced collapse arter partion.

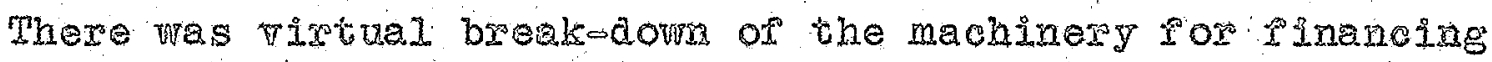
the tea trad end maketing it. Pativion also involved a speedup in jute expopts tyom Chitcegong. The export season for jute and tea colnoide and Chlthagong port was suddenly called apon to olear the ma jor portion of the stocks going abroad. The result tas congestion and encroachnent by jut on storage fajilies.

More than 90 per cent of Pakistan's tea pind its maro ket in tho United Kingdomo Egypt, Candd, Burma, and the United States are some of the othex eustomers or Pakigan's , to8.

Hides and Skins: The annuel production or hides is estimated at $5,149,000$ pieces and that of skins a $7,564,000$ pieces and that of tur and rancy skins at 1,903,000 pieces. Thus Pakistan produces lagge quatities of raw hides and skins. Petstan's chier burers or hides and skins in 19490 50 were the United States (Rs。 $7,400,000)$, Ttaly (Rs. $4,500,000)$, Germany (Rs.. 4,000,000), ard the Unitged Iingdom (RE. 3,600,000)。

The total value of exports to principal countres ror the year 1948-49 and 1949650 is as rollows:

1. Ministry or Economic Arpaits, Intestment Opportunio ties in Pakistan, D. I2。

2. Three Years of Pakistea, $\mathrm{pp} .39-4.0$ 


\section{TABTE X}

VALUE OF SEA-BORATE EXPORTS

TO PRTNCIPAL COUNTRTES

\begin{tabular}{|c|c|c|}
\hline Counctsy & $\begin{array}{l}1948-49 \\
(10 \mathrm{~min} 1 \mathrm{ions}\end{array}$ & $\begin{array}{l}194.9050 \\
0 \times \mathrm{RSO}^{2}\end{array}$ \\
\hline Trited Kingdora & 148 & 172 \\
\hline India & 216 & 77 \\
\hline Uaited states & 88 & 61 \\
\hline Hongkong & 24 & 58 \\
\hline Japara & 12 & 58 \\
\hline Russia & 46 & 4.5 \\
\hline Cormang & 31 & $3 \&$ \\
\hline Itady & 32 & 30 \\
\hline Belgivin & 50 & 24 \\
\hline Crochoslovakid & 27 & 13 \\
\hline
\end{tabular}

\section{IELOPOE:}

The principal iraports of pakistan are cotton and yarn menufactures, machinery, rehicles, oils, coal, sugar, cheno iog Is a drugs。

The seaborne impoxts of roreign merchendse duxing 1948049 and 1949-50 anounted to Rs.109.4 million and 111.4

1.: Three Yoars os Rakistai pp. $39-40$ 
1

mi1iod, xespeetivelyo These rigutes do not take into aco count imports riom India by land.

As mentioned, Pakistan is monly an importer or fixished goods of all categories and an exporter of ram matalals. This charater of hex forelgn trade is cleaxy replected in het composition of trade. The comparative value or prineipal articles of imports rox the years $1948 \mathrm{k}, 9$ and 1949050 is shown in pable XVI.

Some of the othete important imported goods in 1949050 were rubber manucactures (Rs, $17,000,000)$, paper and pasteo board (Rg: $15,700,000)$, vegetable olis, non-essentials (Rs, 24,500,000), dyeing and tanning substances (Rs. 19,400,000), chem cals and chemied preparations (Rs. $14,4,00,000)$

The total value of imports trom the prinelpal suppiexs of Pakistan is giver in Table xuI, page 135 .

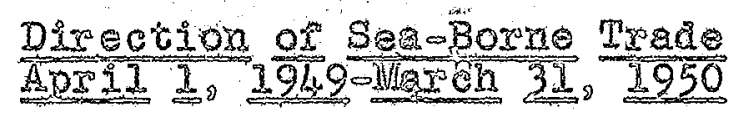

During 1949050 the United Kingdom was the principal buyer of Pakigtan merchandise, and her purchases aggregated about 22 pex cent of the total exports by sea. othex Impor tant morting counties are India, France, the United States, Hongkong, Japan, and Russia.

1. Ministry oi Heonomie APraixs, Basie Facis Qbout Pakistan, Po 22。 


\section{TABIET XVI}

VALUE OF STA-BORNE ITMPORTSI

OF FORYIGIV NARCHANDISE

Cotton piece goods

26.9

25.7

Cotton yarn and buist

11.3

16.4

Machinesy and mill mork

5.7

8.3

Tohioles

407

5.2

Metals and ore

3.4

4.5

O1I minerals

208

4.0

Drugs and medicines

402

2.4

Protislons and oilmen's stores

2.1

3.4

Tobaceo manufacures

$2.7 \quad 3.0$

Instruments and apparatus

2.1

2.0

Hardwase

0.8

1.3

1. Three Years of Pakistan po 36 . 


\section{TABTE XVII}

VATUE OF SEA BORNE IMPORTS?

FROM PRINCIPAI COUNTRIES

\begin{tabular}{|c|c|c|}
\hline Country & $\begin{array}{l}1948049 \\
\text { In minion }\end{array}$ & $\begin{array}{l}1949050 \\
\text { is or Rs. }\end{array}$ \\
\hline Uditod KIngdon & 270 & 348 \\
\hline Ind ja & 449 & 176 \\
\hline United stros & 80 & 120 \\
\hline Japar: & 10 & 94 \\
\hline Italy & 38 & 82 \\
\hline Ching & 69 & 54 \\
\hline Necherands & 13 & 27 \\
\hline Russia & $-\infty$ & 16 \\
\hline Eggot & $\infty$ & 25 \\
\hline
\end{tabular}

Duxing 1949-50 the United Kingom was also the chies expoxting country and claims about 31.2 per cent or pakiso tan's impoxs by sea othex important exporting countries are India, the United States, Japan, ItaIy, and China.

The perentage share of vaxious countries 18 given in Table XVII.

1. Three Iears of Pakistan po 40 


\section{TABIE XTIII}

DIRECTION OF SEA-BORNE TRADE AND

PERCERTAGE SHARE OH TARIOUS COUTTRIES ${ }^{2}$

Apris I, 19k9 allaxeh 31,1950

\begin{tabular}{|c|c|c|c|}
\hline \multicolumn{2}{|l|}{ Exports } & \multicolumn{2}{|l|}{ Inports } \\
\hline Country & $\begin{array}{l}\text { Percentage } \\
\text { share }\end{array}$ & Country & $\begin{array}{l}\text { ercentage } \\
\text { share }\end{array}$ \\
\hline United Kingdom & 22.23 & United Kingaom & $3 I .21$ \\
\hline Irdida & 10.01 & $\operatorname{Ind}$ & 15.27 \\
\hline Franee & 8.73 & United states & 20.75 \\
\hline United States & 7.85 & Japan & 8.46 \\
\hline Hongkong & 7.55 & Ifaly & 7.40 \\
\hline Japara & 6.86 & Chine & 4.83 \\
\hline Russia & 5.81 & Hethexlands & 2041 \\
\hline Germany & botal & Adegt & 2.30 \\
\hline ItaIy & 3.88 & Burema & 2014 \\
\hline Others count zes & 22.64 & other countries & 15.25 \\
\hline$\cdots$ & 100.00 & & 200.00 \\
\hline
\end{tabular}

1. Arinlstry of Economic ArTalrs, Basie Facts about Pakistan, p.26. 


\section{CHAPTER X}

\section{PUBLIC FINANCE}

During the three frean of its entstence as an indepen dent state, Pakigtan has rinally set at xest doubts etw pressed in some quartirs as to its economio stability. The gredictions of rinanciel "experts" berore the bith or Rakiso tan groved atonishingly inaceurate.

The experts torecasted that Pakistan would not be able to stind on its ow logs and meet the expenses required to run the new wate: that it would not have enough forelgn exw change and would have to face a sexlous waravorable balance or trade; that Pakistan cux reney would not command confidence; and that there was no capital in Pakistan and the government would not be able to borrow funds to carry out any develop ment schemes.

Aetrally, the reverse of the above predietions proved correct. The salde prophets overlooked cextain important racts. The rirst was that pakistan would be surplus in food and would not require foroign exchange ror pood purchases abroad to ped her poptilation. The next was that while ino dustry was located in the Indian Union, the major portion of the raw material for industry notably jute, eotton, hides and skins) would be located in the now state or Pakistan. 
Pakistan, it is true, was faced with problems unique in the history of a new gtate caused by the greatest migration ver known, with aisruption of trade, industyy, comerce, inance, communcation, and the entre economic life of the country. These difriculties might well have overwhelned ang well-estalished state: Pakistan at that time was in the process of establishing a ceatral government.

The presentation of surplus bucgets shows that Pakistan has been invulnerole inanoielly. These budgets have been presented in suecesston, with substantial proristons ror agxioulturel and industrial developments.

The pars budget of the central gorernment (19484.49) came as a suxprise and disiliusioned many who bad anticipated a serous dericit. It mas surplus budget with rerenue and

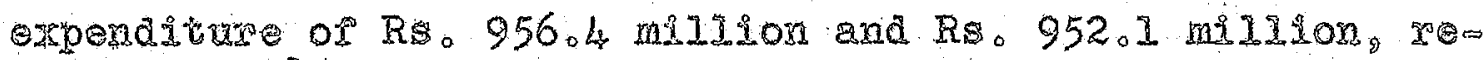
spectrviy. Whon this budgetary surplus is vieved aginst the background of the heary buxden or derense, loss on the working of strategie railways the mass migration or popula tion to takingan, and the allmaround abnomel conditions prevalent it becomes great achlerenent.

The third budget of Pakistan terealed a careful handing of Pakistan's economic regources and a sound inancial posio 2 tion. The budget for 1950-51 revealed a continus growh

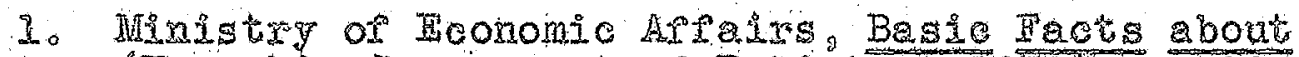

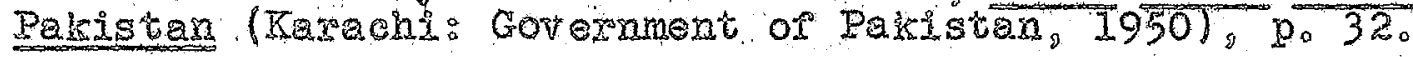
2. Log. Lit. 
or reverue as well as expenditure. The publio revenue has been steadiy growng prom yeax to yeax. In $1947-48$ (seven and a hal months) it stood at $\mathrm{R}_{\mathrm{S}} \mathrm{k} 27.9$ million and in 194849 at Rs。956.4 milion, while in 1949-50. it was Rs。 $1,113.8$ millios. It 1950.51 it has been estimated at Rs. $1,156.4$ milison。

On the other side, the expenditures also shom a marked and continuous increase. In 1947048 (seven and a halt months) this flgure stood at Rs 662 minion, in 1948049 at Rs. 952.1 milion, in 1949050 at Rs。 $1,136.5$ militon, and in $1950-51$ it has been estimated at Ro.1,256.4 milidon。 The chier sources of terenue and heads or expenditure in the budget are shows in table XIX.

\section{Publie Debt}

In ordex to rind the rund recessary for the finaneing of parious development sehemes, the central government deo olded to raise internal loans. The dogision to raise the first Ioan fas taken soon arter the partition, at a we when the governont was beset vith numerous difficulties of gio gantic magntude which would have dissuaded even older govo

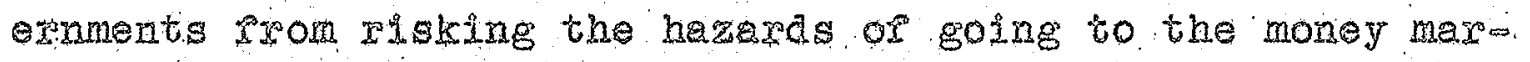
ket ror a loan. But so great has always been the faith or the netion in the economic soundness and tuture prosperity or Pakistan that the irst loan was orerosubseribed in a few hours. Response to subsequent loans hes been no less 
TABLE $X C X$

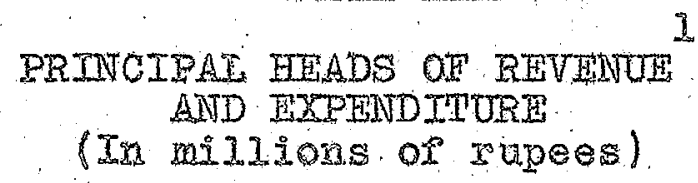

$19480491949-50 \quad 1950-51$
$($ boerised)

GROSS REVTENUE

Principal heads of reverue:

1. Custoris

2. Central exoiss

3. Income and ouporation tazes

4. Sales tax

5. Salt

6. Land revenue, stamps.

7. Propincial exelas

8. 0thez tazes and duties

Total

\begin{tabular}{rrr}
275.0 & 347.5 & 315.0 \\
52.0 & 57.5 & 62.0 \\
65.0 & 90.0 & 95.0 \\
35.0 & 60.0 & 60.0 \\
33.0 & 25.0 & 26.0 \\
3.8 & 4.7 & 4.7 \\
305 & 5.0 & 4.0 \\
2.7 & 5.8 & 6.2 \\
\hline 470.0 & 595.5 & 573.8 \\
376.5 & 413.5 & 42404 \\
109.9 & 129.8 & 138.2 \\
00 & 00 & 20.0 \\
\hline 956.6 & 1.138 .8 & 1.156 .4
\end{tabular}

Reilways, post, and telegraphs. Ouhere heads

How taxation proposals

TOTAI GROSS RHTENUE 
encouraging and enthusiastid. In this may the gorexnment os Pakistan has so fax Iaised Intexnel loans to the extent of Rs. 705.7 minlizon。

1. Mfinistry of Economic Artairs, Pakistan Development Sehemes (Rarachi: Gorernment of Pakistañ 1950), D. 3. 


\section{BIBLIOGRAPHY}

Sourees clted

Brown, Norman Wo, India, Pakigtan, Ceylono New Zork: Corne11 Universiby Puess. 195I。

Department of Publications and Foreign Publieity, this Land of Pakisten. Karachi: Government of Pakistan, 1948.

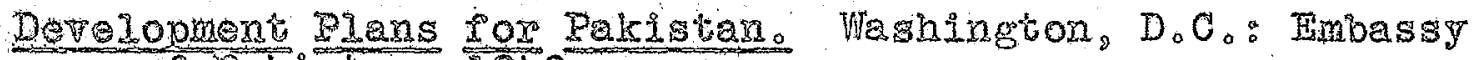
or Raki stan 196,9

Kand, Iiaguat Ali, Speoches by Lieguat All Than, Cambridge: Haxvard Univergity Press 1950 。

Hisistry of Commerce, summery of SeanBorne Foreign Trade of Pakistan. Karachi: Gorernment of Paki S6an, 1948.49: 1949050 .

nhinistry of Economie Arialrs. Karachio Goternment of Pakisw tean.

Basie Facts about Pakigtan, 2950.

Tnvestment Qpposiunit tes in Pakistan, 1950 . Pakistan Develooment Sehemes, 1950 .

Ministry or Induscries. Karachi: Gowernment or Pakistan。 Industry in Pakistan, 1950。

Mining Industry in Pakistan. 1950。

Pakistan Industrit. 1969.

Treansport and Industry, 1950。

Pakistan. Londona Thomas de la Rue and Co., Itdo, 1949\%

Pakistan a The Struggle of Nation. Washlagton, $D, C_{0}:$ Embassy 08 Pakistang 39490

Symonds, Richard, The Making of Pakistano London: Faber and Fabex, 1949:

The First Tear. Karachi Gorerument of Rakistan, 194.8

The Second Year. Karachi: Government of Pakistan, 2949.

Ihree Tears of Pakistain. Karachi: Goverment of Pakistan, 2950 . 
Weath dugust 1950 .

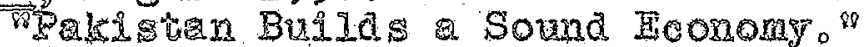

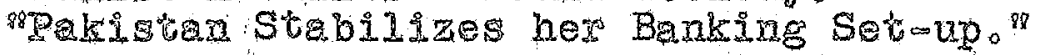

Sources sound Userul but not Clted

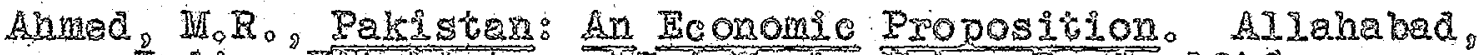

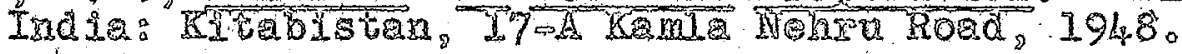

Ali, Hanid, Mrojected Irdustrial Development or Pakistan, The Asiatie ReViev, July 1950, p。1031。

Andru, Jor and Othors, pstate and Pxipate Entexprise in Pakistan, Far Eastern Survery Apxil 4, 195I, po61。

Baxton, William, Whe Buxghey Hision Report, Pastern World, Norembers $2950 ; \mathrm{p} .35$.

Brome, Goso, Mive Year Industrial Development Progran Prom ceding in Pakisten, Foreigh Trade, Januery lis 1950 , Do Itso

Chhzbber, $H_{0} I_{0}$ Adyanced Economic Goography of India and Pakistan, Chowk Berare, India: Nand Kishore \& Brog.g 1949 \%

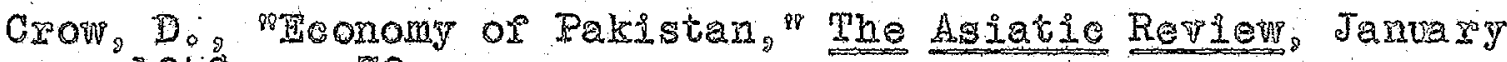
$1948, p=720$

Dean, Vollo, Pakistan Strives to Build Hodern Economy,

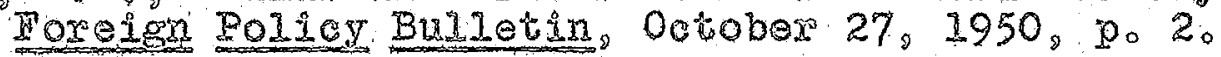

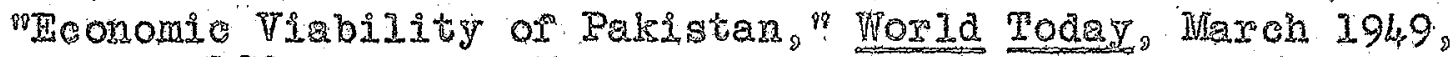
p. 123 .

Indian and Pakistan Yeaxbook, 1949. Bombay: Times or India P.ess, 2950 。

Chosch, $B_{0} B_{0}$ Indian Eeononies anc Pakistani Peonomios

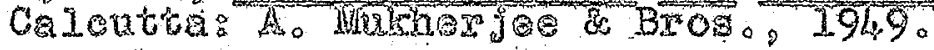

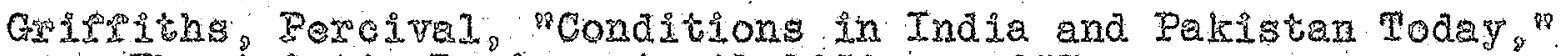
The AsIatie Retier, Apsiz 1950,20957。

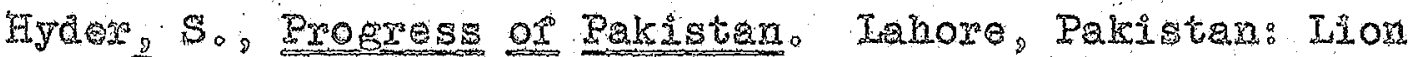
Press 1950 .

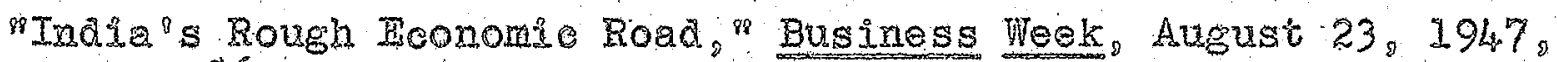
p. 86 . 
"Industial Polioy in Pakistan " Intexnational Iaboux Revien August 1948, D。211。

Islem The Religion of Peace Washlngton. D.C.: Wa shingtion Mosque Foundation, Ine. 1948.

Whan, $U_{0}$ and Arshad, Ao, Host Pakiston in Maps and Statistios. Thare: Ferozson, I949\%

MeGhee, $G_{0} C_{0}$. Mecomomic Outiook in India and Pakistan, The United States State Departnent Bulletin, Ootober 30 . 1950.2068 .

Ministy or Industries: Kaxachi: Corernment of Pakistan. A Budger or Pover Resourcas.

A Budget of Resouroes and Reguirenents of Technieal Pexsonnel.

Alnancial Assistance to Industion.

Fuel Bude or pakitian.

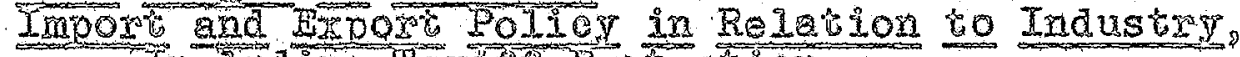
Inotuding Teris protection.

Inqustrel Aderess ox the Honourable Prome Minis ter, and Oponing Speech on the Honourable Hinister or Indus

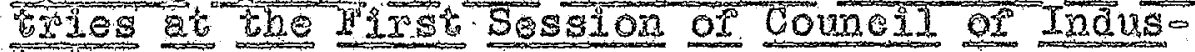
treses.

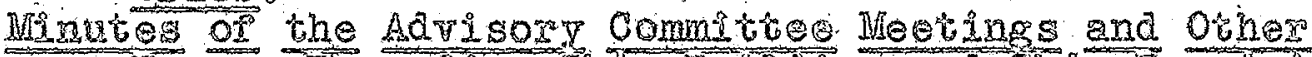

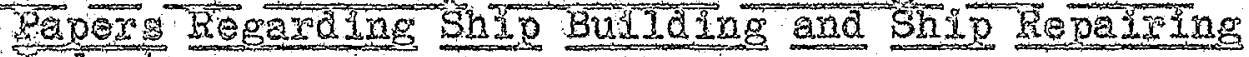
moustis.

Pakjegan Qnd Industgo.

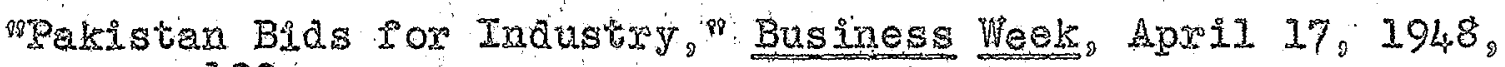
p. 122。

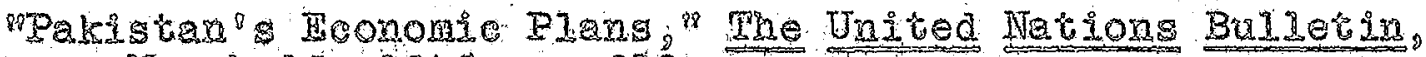
Mfox oh $25,1948,80219$ 。

Blthwe 12, M.B.; Introduotion to Paklstan. London: Arthut Probsthand, 1948。

Quxeshi, Ao "Econonie Basis or Pakistan "The Asiatie Repierp Agxil 1947, 20.260.

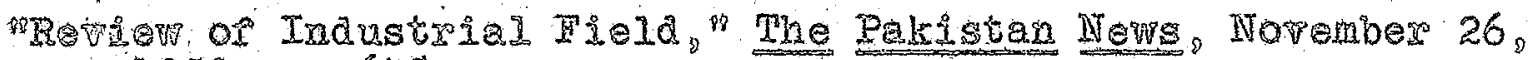
$1950,0.648$.

Shate. Io Rinth or an Honomy the United Nations World, Norember 1950 , po 50 。

Shepwar I, Io, Bais or Economi Development in Pakistan, Poejie Araixs, Decomber 1949, po 381 . 
Spate, O.H, Ko, praxtion of India and the Prospects or

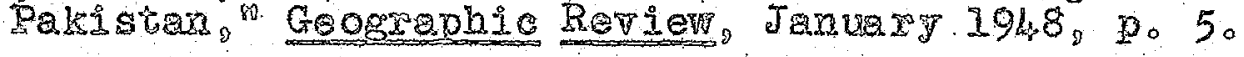

Swaninethan, VoS。 "Pakistan Problems and Prospects? The HIdale Ease Journa 1, Oetober $1950 \%$ D. 467 .

Fakil, Collog Ponomie Consequenoes of Divided India. London: Laza and Co. Lita 1950 。

Waugh, An India and Rakistan: Bonomic Hects of Partio tion, The Asjatie Revien, April 1948, $p_{0} 113$. 


\section{APPENDIX \\ LIFE OF MOHAMMAD AII JINNAE, THE FOUDDER OF PAIISTAN}

Today and rexy day. Pakistan remembers Quid-iodzam (the great leadax), Mohamma Ali Jinneho Tew men in history hav created and sounded a state by peacolul agtation: ho took an inchoate mess and moulded a naton.

Mohamad AlI Jinnah $(18760194.8)$ was born in Karach of - wealthy mexchant ramily. At the age of simteen he went to Ergland were he quelified as a barrister or Lincoln's Inn. On his return, he earned an inmedate reputation and lueram. tive prectice. He organized the 200 million Muslins of India and altered the destinies of onesifth of the human raco.

Neither risionary nor seer, he preached no Utopla. Pakistan was intended as the solution to a problem whioh had depied solution por a hundred yearsocthe replacement of loreign xule.

An intense patiot with a lifetime serrice to the nac tional cause. "Jinnah tejected the doetrine or the United India when convinced of its wareality. Ho considexed it not merely a myth, but a mill stone。 For bondage in unity he subo stituted stroedom in separation. 
To Jinnah, the ide of relegating 100 millions to a perpetuel minoriby sutus was intolerable. Hindus and Muso lims both believed in demooracy: why not, thererore, democo racy in which they could develop and progress, each aceordo ing to its om culture and genjus?

During the greatest exodus la buman histoxy, he oxgan ized a government and laja the rowndations of the biggest

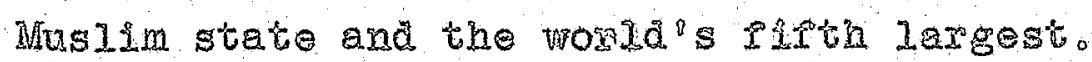

He told his poople how it had bean ahiered: raith. wity and discipline. Borr in txaraid, it was the basis or

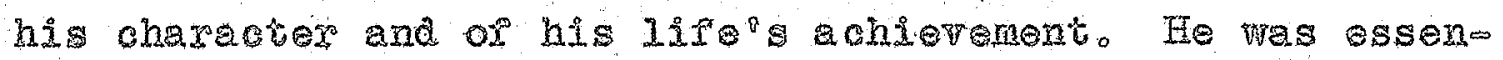
tially a realig who book these three ideals and rorged them into weapon which none could mithstand:

He died as ho had lived, in the service of his people. 


\section{VITA}

Niaz Mohamnad was born January, 1914 in Patiala (India)。 He received his elementary and bigh school education in New Delhi, Simla, graduating from Musilm Figh School, Ambala, In $1931 . \mathrm{He}$ attended the Mohindra College, Patiala, and obtained his Faculty of Arts degree from the Punjab Univero sity in 1933. From 1933 to 1936 he studied at the Hailey College or Commerce, Iahore, Punjab University, and graduated With the degree or Bachelor of Commerce.

He entered the (undivided) Government of. India employ in 1938 and was attached to the office of the iconomic Ado viser. He was deputed to work as an Investigator in the Planning and Development Department of the Government of India 1943-1946. He reverted to the office of the Economic Adrisex as Research Officer in 1946. In 1947 when partition of India took place, he opted for Pakistan, and has been working since then as Research Orfucer in the office of the Economic Adviser, Mlinistry of Economic Affairs, Government or Pakistan.

He joined the University of Arizona as a graduate stum dent majoring in Economics in the rall or 1950 .

While making the study of economic development in Pakistan, this writer, as a student of economics, has tried 
to appoach the problem in an unbiased way. Consciously he has tried to investigate and formulate his opinions in an unprejudiced way, but subconseiously he is not sure whether he has kept the tradition As rar as possible, the data used in the study have been taken from Government of Pakistan publications.

At the time of partition, the witer suffered the loss of property, and some of his relatives were either killed or injured in the disturbances which took place in India in 1947. Every effort has been taken, however, to keep away the personal sentiments while approaching the problem.

The undivided Government of India published in 1947 the writer study of Cabinet Mission Flan, A Statistical Study of Eroposed Groups of India." 